\title{
CONCEPÇÕES DE PROFISSIONAIS DE EQUIPES DE SAÚDE DA FAMÍLIA SOBRE VIOLÊNCIA DE GÊNERO
}

Dissertação apresentada à Escola de Enfermagem da Universidade de São Paulo para obtenção do título de mestre em Enfermagem.

Área de Concentração:

Enfermagem em Saúde Coletiva

Orientadora:

Profa. Dra. Rosa Maria Godoy Serpa da Fonseca

\section{SÃO PAULO}




\section{Agradecimentos}

Agradeço o apoio das pessoas que direta ou indiretamente colaboraram para a realização deste trabalho:

À minha mãe amada, Ao meu companheiro, Ao meu pai (in memorium), À minha sogra, Às minhas irmãs e meus irmãos, Às minhas sobrinhas e meus sobrinhos, Às minhas cunhadas e meus cunhados, Às minhas amigas e meus amigos, Às minhas colegas de trabalho e aos meus colegas, Às amigas e amigos que fiz durante esse desafio, Às mulheres que me permitiram atendê-las e conhecê-las, Às alunas que me possibilitam trocas, Às professoras da Escola de Enfermagem, Às professoras que participaram da banca de qualificação, Às funcionárias da Escola de Enfermagem, Às profissionais e aos profissionais do PSF de Araraquara,

E um agradecimento especial à minha orientadora, Profa. Dra. Rosa Maria Godoy Serpa da Fonseca 
"Naquele momento, essa foi a visão de mundo com a qual realizei este trabalho. Mas, o que se pretende é contribuir de alguma maneira para a discussão da violência de gênero".

Neusa, abril/2007 


\section{RESUMO}

Este estudo investigou a concepção de violência de gênero em 12 equipes de saúde da família do Município de Araraquara. Para tanto, os objetivos do estudo foram: conhecer e analisar à luz de gênero a visão dos profissionais das equipes de Saúde da Família acerca de homem e mulher; identificar e analisar, à luz de gênero, a percepção dos membros das equipes sobre a violência de gênero e detectar e analisar, à luz de gênero, as contradições que permeiam as concepções dos profissionais em relação a mulher, homem e violência de gênero. Os dados foram coletados durante uma oficina de trabalho e submetidos à análise de conteúdo, resultando em duas categorias empíricas "Homem e mulher no mesmo barco social" e "Violência de gênero". Foram priorizados os temas mais relevantes de acordo com o objeto de estudo, aderentes às categorias analíticas gênero e violência de gênero. Os resultados evidenciaram que a violência de gênero não é percebida pelos profissionais como originárias da construção social da masculinidade e da feminilidade. Ao mesmo tempo em que se percebe avanços no sentido de uma visão mais crítica a respeito da influência dos processos de construção da masculinidade e da feminilidade na identidade de gênero, coexistem com esta, visões conservadoras respaldadas na concepção de homem-provedor e mulherreprodutora, condizentes com o senso comum. Da mesma maneira comportam-se os temas relacionados à violência de gênero, coexistindo percepções conservadoras e transformadoras. Esta mescla de concepções e posicionamentos confirma a necessidade de ampliar a qualificação profissional para capacitar os trabalhadores para lidar com um fenômeno tão complexo embora comum na realidade do território abrangido pelo Programa de Saúde da Família.

Palavras-chave: violência contra a mulher; violência de gênero; Programa de Saúde da Família 


\section{ABSTRACT}

This study investigated gender-related violence in 12 family health staffs in Araraquara city. The objectives were to get to know and to analyze, from the gender perspective: the health professionals point of view about man and woman, the professionals' perceptions about gender-related violence and the contradictions that exist in the professionals' conceptions about woman, man and violence against woman. Data were collected during a workshop and the content was analyzed through two different empirical categories: "man and woman in the same 'social boat"' and "gender-related violence". The more relevant themes related to the object of this study received more attention, and were included in two analytical categories: gender and gender-related violence. The results showed that the participants do not perceive gender-related violence as something that comes from the social construction of masculinity and femininity. They do have a critical view about those processes of social construction, but they still have conservative opinions about man and woman's roles: the provider-man and the reproducer-woman; and this is in agreement with the common sense. Discussions about gender-related violence follow the same pattern: with conservative and transforming perceptions at the same time. This mixture of different positionings shows the need to broaden the professional qualifications to deal with this complex, still common, reality of domestic violence inside the territories of the Brazilian Family Health Program.

Key words: violence against woman; gender violence; Family Health Program. 


\section{SUMÁRIO}

\section{RESUMO}

\section{ABSTRACT}

\section{APRESENTAÇÃO}

10 PROBLEMA E O OBJETO DE ESTUDO

1.1 VIOLÊNCIA DE GÊNERO E VIOLÊNCIA CONTRA

AS MULHERES

1.2 CARACTERÍSTICAS DAS VÍTIMAS E DO ATO VIOLENTO 18

1.3 VIOLÊNCIA DE GÊNERO E AGRAVOS À SAÚDE

1.4 VIOLÊNCIA E ATENÇÃO À SAÚDE NO PROGRAMA DE SAÚDE DA FAMÍLIA (PSF) 24

2 OBJETIVOS 29

3 MÉTODO 30

3.1 REFERENCIAL TEÓRICO 30

3.1.1 Gênero e violência de gênero $\quad 30$

3.2 PROCEDIMENTOS METODOLÓGICOS 35

3.2.1 Cenário do estudo $\quad 35$

3.2.2 Sujeitos da pesquisa e coleta de dados $\quad 35$

3.2.3 Procedimentos éticos 40

3.2.4 Tratamento e análise de dados $\quad 40$

4 RESULTADOS E DISCUSSÃO 42

4.1 HOMEM E MULHER NO MESMO BARCO SOCIAL: METÁFORA GERANDO METÁFORA

4.1.1 Mulheres e homens: igualdade e diferença, papéis e identidades

4.1.2 Características do feminino e do masculino - emoção 
e razão

4.1.3 Contra a negação do saber e do trabalho da mulher

4.1.4 Mulheres, homens e trabalho doméstico

4.1.5 Diferença, relação complementar, futuro e eqüidade

60

4.1.6 Superando as diferenças

63

4.2 VIOLÊNCIA DE GÊNERO: O QUE PENSAM OS TRABALHADORES DO PROGRAMA DE SAÚDE DA FAMÍLIA 65

4.2.1 Em mulher não se bate nem com uma flor 66

4.2.2 Mulher frágil, homem forte: relação desigual gera violência $\mathbf{7 0}$

4.2.3 Violência de gênero: outros envolvidos

4.2.4 Violência e drogadição - a combinação ideal

da subalternidade

78

4.2.5 $O$ atendimento à mulher em situação de violência: entre a (im)possibilidade e 0 acolhimento

4.2.6 O acolhimento e a escuta qualificada

85

4.2.7 0 preconceito reconhecido como barreira à assistência

92

5 CONSIDERAÇÕES FINAIS 


\section{APRESENTAÇÃO}

Sou assistente social, exerço minha profissão há cerca de 17 anos e, na minha trajetória, tenho lidado com vários fenômenos, entre os quais a violência de gênero. Há 12 anos, trabalho na Divisão de Promoção Social da Coseas (Coordenadoria de Assistência Social da Universidade de São Paulo), atendendo alunos da graduação e pós-graduação. Além do atendimento individual aos estudantes, sou responsável pelo projeto denominado "SOS Mulher" que tem por finalidade atender, acolher, orientar e encaminhar para recursos especializados alunas e alunos moradores do Conjunto Residencial da Universidade de São Paulo (Crusp) e funcionárias da Coseas que vivenciam relações violentas de gênero. A busca por aprimoramento resultou no meu ingresso no Programa de Pós-Graduação da Escola de Enfermagem, no Departamento de Enfermagem em Saúde Coletiva da Universidade de São Paulo.

A opção pela violência de gênero como tema de pesquisa se deu a partir da minha participação na Oficina de Trabalho "Mulher e violência: reconstruindo a assistência no âmbito do Programa de Saúde da Família", promovida pela Secretaria Municipal de Saúde de Araraquara e pelo Centro de Referência da Mulher Helleieth Saffioti (CRMHS). Foi realizada de 21 a 25 de novembro de 2005, tendo como participantes profissionais das Equipes de Saúde da Família daquele Município, como parte do projeto intitulado "Práticas profissionais e violência contra as mulheres: um recorte de gênero e classe social". O projeto é financiado pelo Conselho Nacional de Desenvolvimento Científico e Tecnológico (CNPq) e integra a produção do grupo de Pesquisa "Gênero, Saúde e Enfermagem", do Departamento de Enfermagem em Saúde Coletiva da Escola de Enfermagem da Universidade de São Paulo, cadastrado no Diretório de Grupos de Pesquisa do CNPq (Conselho Nacional de 
Desenvolvimento Científico e Tecnológico), sob a coordenação da Profa. Dra. Rosa Maria Godoy Serpa da Fonseca.

Tratou-se de uma oportunidade para aprimorar meus conhecimentos e compreender os meandros da assistência prestada às mulheres que vivenciam relações de gênero violentas, bem como os conflitos vivenciados pelos profissionais que, como eu, na sua prática, se deparam com dificuldades muitas vezes mais relacionadas à sua visão de mundo e conseqüentes posicionamentos, do que técnicas. Possibilitou-me também traçar um paralelo entre o atendimento prestado nas áreas da saúde e do serviço social, no enfrentamento de um problema que aflige grande parte da nossa população, tanto no âmbito das famílias como das mulheres que convivem, trabalham e estudam nesta Universidade.

Para se ter uma idéia da magnitude do problema, por meio dos atendimentos realizados, pode-se pontuar que, em Araraquara, em 2001, passaram pelo Centro de Referência da Mulher Helleieth Saffioti 81 mulheres agredidas. Em 2005, esse número passou para 553 mulheres que buscaram ajuda por vivenciarem situações de violência física, psicológica ou sexual, geralmente no âmbito doméstico. Cerca da metade delas é casada ou vive em situação marital estável e o agressor é o próprio parceiro (Polezze, 2005).

No Crusp, sobre violência de gênero, foram relatados 18 casos em 2005 e 2006, casos estes que chegaram ao conhecimento da equipe de Segurança Comunitária do Serviço de Atuação Comunitária da Divisão de Promoção Social da Coseas. Quanto ao perfil das agredidas, 10 eram da pós-graduação, 7 da graduação e para 1 não havia relato do tipo de vínculo com a universidade. Quanto ao curso freqüentado pelo agressor, 5 eram da pós-graduação, 7 da graduação e havia $6 \mathrm{com}$ vínculo não identificado. Há que se pontuar que o número registrado de ocorrências pode ser ainda maior, pois "uma porcentagem muito pequena das mulheres agredidas denuncia o crime ou busca alguma forma de ajuda" (Schraiber et al., 2005:140). 
As relações que essas mulheres mantinham com o agressor eram: como esposa, companheira ou namorada, em 6 casos, como amiga, em 3, conhecida, em 4 e em 5 casos, o agressor era desconhecido. Os tipos de violência referidos foram psicológica, em 13 casos e física em 5 . Quanto à freqüência, 5 mulheres relataram terem sido agredidas uma única vez, 1 delas era agredida freqüentemente e 12 não relataram a freqüência das agressões. Alcoolismo, drogadição, problemas mentais e possíveis associações dessas condições com o agressor não foram registrados, embora os indícios estivessem evidentes.

O desvelamento dessa realidade só será obtido quando o fenômeno for conhecido nos seus meandros e especificidades, entre elas, o posicionamento dos profissionais que lidam com ele, pois a visão de mundo que subjaz a este posicionamento é que verdadeiramente ancora as ações componentes da prática, sejam elas no campo da saúde, sejam no do serviço social.

Assim, conhecendo o que os profissionais das Equipes de Saúde da Família pensam e sentem em relação à violência de gênero, poderei também eu instrumentalizar minhas ações no trabalho junto às alunas e trabalhadoras sob minha responsabilidade. 


\section{O PROBLEMA E O OBJETO DE ESTUDO}

O fenômeno violência sempre esteve presente em todo o mundo e ocorre de várias formas, diferenciando-se conforme as sociedades e as culturas onde se apresenta.

Segundo Almeida e Sousa, "violência" provém do latim "violentia, violentiae", termo que, no início do século XIII, empregava-se para significar "abuso da força". No século XVI, a forma verbal "exercer violência, violentar" significava agir sobre alguém ou fazer esse agir contra sua vontade mediante força ou intimidação (Sousa, 2004).

A Organização Mundial da Saúde define violência como:

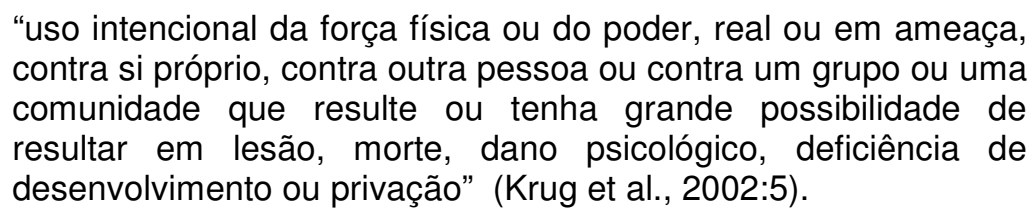

Saffioti a define como "a ruptura de qualquer forma de integridade da vítima; integridade física, integridade psíquica, integridade sexual, integridade moral" (Saffioti, 2004:17). Esse conceito é integralizador a ponto de abranger todo e qualquer ato que fira direitos humanos, porém a singularidade do sentimento de ruptura das integridades é algo muito particular, o que resulta numa sensação de violência variável de pessoa para pessoa.

A violência nem se sempre se apresenta como um acontecimento, um fato, claro e transparente por si mesmo e nem sempre é visível. $O$ ato violento pode se insinuar como um ato natural, cuja essência passa desapercebida. Perceber a violência exige esforço para descaracterizá-la como ato rotineiro, natural e inscrito na ordem das coisas. São os hábitos, costumes, as leis explícitas ou implícitas que encobrem certas práticas violentas, tidas como normais na vida em sociedade que dificultam reconhecer, de imediato, o caráter violento dos atos. Essa maneira de pensar e agir leva à institucionalização da desigualdade e à naturalização da 
distinção entre os seres humanos. A violência da desigualdade aparece em condições históricas específicas e se perpetua, mesmo que se modifiquem as suas maneiras de aparecer (Odalia, 2004).

Hoje é praticamente unânime, por exemplo, a idéia de que a violência não faz parte da natureza humana e que não tem raízes somente biológicas. Trata-se de um complexo e dinâmico fenômeno biopsicossocial e seu espaço de criação e desenvolvimento é a vida em sociedade. (Minayo, 1994:1) A violência deve ser concebida como um fenômeno social com implicações subjetivas, construído nas relações estabelecidas entre as pessoas, instituições e grupos. Nesse sentido, a sua análise exige um olhar multidimensional que considere os aspectos estruturais, como a economia, cultura, história e os grupos constituintes da sociedade e conjunturais, como o contexto na qual a violência ocorre (Barros, 2000).

Para Bráulio de Almeida e Sousa, na sua expressão comportamental, violência é sinônimo da dominação pela coação e esta dominação visará sempre o outro, os outros, um grupo ou grupos, uma instituição, um poder político ou o exercício desse poder, a dominação de um povo, de povos, ou do mundo. Dominar é negar, é não reconhecer, é impedir pelo exercício da força a expressão de uma alteridade: de um sujeito, de um movimento de opinião, de uma força social, de uma minoria, de um povo (Sousa, 2004).

A violência é um problema da sociedade que é tratado no âmbito da justiça, da segurança pública e também como objeto de movimentos sociais, razão pela qual a saúde não pode tomá-la como um objeto exclusivamente seu. A articulação da violência com a saúde aparece no conceito ampliado de saúde e se refere a tudo o que significa agravo e ameaça à vida, às condições de trabalho, às relações interpessoais e à qualidade da existência. Faz parte do universo da saúde pública porque, num sentido mais restrito, afeta a saúde, por provocar lesões, traumas físicos e emocionais, até mesmo a morte.

"A violência, pelo número de vítimas e a magnitude de seqüelas orgânicas e emocionais que produz, adquiriu um caráter endêmico e se converteu num problema de saúde pública em muitos países (...). O setor saúde constitui a encruzilhada para onde convergem todos os corolários da violência, pela pressão 
que exercem suas vítimas sobre os serviços de urgência, atenção especializada, reabilitação física, psicológica e de assistência social" (Opas, 1993 apud Miyano, 2006:49).

\subsection{VIOLÊNCIA DE GÊNERO E VIOLÊNCIA CONTRA AS MULHERES}

O mundo é masculino no que se refere à ideologia que predomina na sociedade. A cultura baseada na diferença entre as características físicas dos homens e das mulheres reforça essa ideologia, no que tange às relações. Embora em constante transformação, a sociedade androcêntrica reitera a assimetria das relações entre homens e mulheres, trazendo em seu âmago vários problemas, entre eles o da violência de gênero.

Para a Organização das Nações Unidas (ONU), violência de gênero é "qualquer ato de violência baseado na diferença de gênero, que resulte em sofrimentos e danos físicos, sexuais e psicológicos da mulher; inclusive ameaças de tais atos, coerção e privação da liberdade seja na vida pública ou privada" (Ipas Brasil, 1992). Historicamente, a denominação do que hoje é tido como violência de gênero foi sendo vista de forma diferente pelas (os) estudiosas (os) do tema. No final dos anos 70, a partir das mobilizações feministas, motivadas pelo assassinato de mulheres, a expressão violência contra a mulher passou a fazer parte do saber comum.

Nos anos 80, evidenciaram-se ainda mais denúncias de espancamentos e maus tratos conjugais. A partir dos anos 90, com o impulso dos estudos de gênero no Brasil, alguns autores passaram a usar a categoria violência de gênero para designar a violência contra a mulher praticada pelo homem (Saffiotti, Almeida, 1995). Em decorrência de grande parte da violência contra a mulher ocorrer no âmbito doméstico, conjugal ou familiar, a categoria passou a ser usada também como sinônimo de violência doméstica (Araújo et al., 2004). Neste trabalho, adotar-se-á o termo violência de gênero referindo-se à violência perpetrada pelo homem contra a mulher, 
embora na atualidade o termo seja utilizado também para homens que são submetidos a relações violentas e sofrem suas conseqüências.

Quanto aos serviços, a demanda por atendimento das vítimas incentivou a criação de recursos sociais, tais como SOS Mulher e delegacias especiais de atendimento à mulher. Segundo Schraiber et al. (2002), as delegacias, as casas-abrigo e os centros de referência multiprofissionais têm enfocado, principalmente, a violência física e sexual perpetrada por parceiros e ex-parceiros da mulher. Posteriormente, surgiram os serviços de atenção à violência sexual para a prevenção e profilaxia de doenças sexualmente transmissíveis (DST), de gravidez indesejada e para a realização de aborto legal.

No cenário nacional e internacional, intensificam-se estudos a respeito de violência de gênero, evidenciando-a sob vários enfoques. Isso não se deve somente ao fato de o fenômeno ter saído do espaço do privado e ter entrado no domínio público, mas também porque vem ganhando visibilidade em razão da sua magnitude e vice-versa.

A Declaração de Viena (1993) sobre Direitos Humanos define que "os direitos humanos das mulheres e das meninas são inalienáveis e constituem parte integral e indivisível dos direitos humanos universais" e, portanto, fazem parte da agenda da comunidade internacional. Não assegurar esses direitos seria, por conseqüência, uma violação dos direitos humanos universais. Além da Declaração de Viena, a Lei nํ⒒340, conhecida como "Lei Maria da Penha" (Brasil, 2006), apesar das críticas que têm sofrido por perpetrar apenas a punição, é um importante instrumento de defesa dos direitos e do enfrentamento da violência contra as mulheres e meninas no Brasil.

Segundo a Organização Mundial de Saúde (OMS), quase metade das mulheres assassinadas é morta pelo marido ou namorado, atual ou ex. A violência responde por aproximadamente $7 \%$ de todas as mortes de mulheres entre 15 a 44 anos no mundo todo. Em alguns países, até $69 \%$ das mulheres entrevistadas relatam terem sido agredidas fisicamente e até $47 \%$ declaram que sua primeira relação sexual foi forçada (Krug et al., 
2002).

No Brasil, pesquisa da Fundação Perseu Abramo realizada em outubro de 2001, em 187 municípios de 24 Estados das cinco macrorregiões, intitulada "A mulher brasileira nos espaços públicos e privados", coletou informações entre mulheres a partir de 15 anos e denunciou que a cada 15 segundos, uma mulher é espancada por um homem no Brasil, estimando mais de 2 milhões de mulheres espancadas a cada ano por maridos ou namorados, atuais e antigos (Fundação Perseu Abramo, 2006).

Segundo a mesma pesquisa, cerca de uma em cada cinco brasileiras (19\%) declara espontaneamente ter sofrido algum tipo de violência por parte de algum homem: 16\% relatam casos de violência física, $2 \%$ citam alguma violência psíquica e 1\% lembra do assédio sexual. É difícil caracterizar nos estudos, com precisão, a prevalência do tipo de violência de gênero: física, sexual ou psicológica. Isso se deve ao fato de que a maioria das ocorrências apresenta-se em conjunto numa mesma amostra ou até num mesmo caso. A conduta do agressor pode ser mais ou menos grave. Por isso, são evidenciadas ora a violência psicológica, ora a física, ora a sexual e até mesmo sua confluência.

Para Schraiber et al. (2005:39), na maioria dos casos há uma superposição das formas de violência psicológica, física e sexual. "Além disso, ao contrário dos homens que têm como principal agressor um desconhecido, as mulheres encontram em seus parceiros íntimos seus principais agressores, seguidos de outros familiares do sexo masculino".

Saffioti (2004:75) reafirma que "as violências físicas, sexual, emocional e moral não ocorrem isoladamente". Para a autora, qualquer que seja a forma assumida pela agressão, a violência emocional e moral estão sempre presentes.

Os homens que praticam atos violentos contra as mulheres são, com grande freqüência, íntimos da mulher agredida. Ex-parceiros também aparecem como perpetradores em 35\% dos eventos (Schraiber et al., 2002).

As causas alegadas para a violência parecem referir-se ao tradicional 
controle do homem sobre a mulher baseado em seu papel de provedor. A resistência à sua transição, tanto por parte do parceiro como da parceira, radicaliza conflitos e colabora para a ocorrência da violência, inclusive sexual, entre o casal (Dantas-Berger, 2003).

O desemprego do parceiro é apontado como desencadeador de episódios de violência (Saffioti, 2004; Menezes et al., 2003). Outras questões, como ciúme, podem ser focos de discussão, fenômenos que, em geral, são exacerbados pelo consumo problemático de álcool. Associação significativa entre o uso de álcool e drogas e o ato violento foi encontrada por vários autores (Adeodato et al., 2005; Menezes et al., 2003; Valdez Rojas et al., 2002; Galvão, 2002; Meneghel et al., 2000).

No Brasil, em setembro de 2004, em capitais e cidades menores, o Instituto Patrícia Galvão realizou um estudo sobre "o que a sociedade pensa sobre a violência contra as mulheres" e teve como base 2.002 entrevistas realizadas com homens e mulheres de 16 anos ou mais, com diferentes níveis de escolaridade e renda. O estudo revelou que há um alto grau de rejeição contra a violência de gênero, pois $82 \%$ dos entrevistados responderam que não existe nenhuma situação que justifique a agressão do homem à sua mulher (Instituto Patrícia Galvão, s/d). Apesar disso, persiste as altas taxas desse fenômeno.

A aceitabilidade da violência de gênero tem um papel importante na formatação do ambiente social; em contrapartida, pode auxiliar no aumento ou diminuição da violência (Langely, Levy, 1980; Gracia, Herrero, 2006). Há diferentes níveis de aceitabilidade. Na União Européia, a alta aceitabilidade social está associada à culpa da vítima, ou seja, à mulher. Nos países em que há empoderamento de gênero, o número de pessoas que não as culpam é maior, porém ainda há, na União Européia, uma atitude amplamente distribuída de responsabilizar as mulheres pela violência que sofrem (Gracia, Herrero, 2006).

Em Nova York, um estudo realizado mediante entrevista por telefone junto a 1.200 pessoas obteve como resultado que a maior parte delas pensava na violência dentro de seu próprio contexto, em relação aos seus 
problemas individuais, seus próprios relacionamentos e da sua família, e não como um problema com raízes na sociedade e na cultura. Poucos achavam que as mulheres seriam as causadoras da violência contra si próprias e um quarto da amostra (300 pessoas) acreditava que algumas mulheres queriam ser violentadas. Em contrapartida, a maioria pensava que as mulheres poderiam finalizar os relacionamentos abusivos (Worden, Carlson, 2005).

Embora a sociedade, de uma maneira geral, demonstre rejeitar a violência de gênero, os números captados na pesquisa da Fundação Perseu Abramo e no estudo de Garcia-Moreno et al. indicam o inverso: a sua alta prevalência (Garcia-Moreno et al., 2006). Segundo as estatísticas, a mulher é a maior vítima da violência por parte do sexo oposto: em $95 \%$ dos casos de violência praticada contra a mulher, o homem é o agressor (Araújo et al., 2004).

Ocorre que a notificação do delito é evitada por grande número de mulheres por vários motivos, dentre eles, a dependência emocional, por se considerarem inferior ao agressor (Garbin et al., 2006) por descrédito e pela morosidade da justiça, (Oshikata et al., 2005) medo (Garbin et al., 2006; Oshikata et al., 2005), pela noção de inefetividade do sistema e por desconhecimento dos direitos legais (Reis et al., 2004). A literatura mostra ainda que uma das causas que contribuem para o baixo índice de denúncias é que a maioria das agressões ocorre em ambientes familiares ou é praticada por pessoas conhecidas, e existe um vínculo sentimental ou hierárquico entre os agressores e as vítimas (Oshikata et al., 2005).

Seja por descrédito no sistema jurídico ou até mesmo aceitação da sua condição de subalternidade, outro fato que corrobora para aumentar a gravidade do problema da violência de gênero é a impunidade, que é fato no mundo todo e também no Brasil. É importante ressaltar que uma das formas de coibir a violência é buscar respaldo na justiça, denunciando o agressor. A impunidade, por exemplo, inspirou recentemente a aprovação da Lei Maria da Penha, que estabelece a imediata prisão do agressor doméstico no momento da queixa policial (Brasil, 2006). 


\subsection{CARACTERÍSTICAS DAS VÍTIMAS E DO ATO VIOLENTO}

A vítima da violência de gênero tem algumas características demográficas peculiares, de acordo com diversos estudos. Trata-se de uma mulher jovem, de menos de 30 anos, (Reichenheim et al., 2006; Galvão, 2002) com pouca escolaridade (Reichenheim et al., 2006; Kronbauer, Meneghel, 2005; Oshikata, 2005; Menezes et al., 2003; Alvarado, Erazo, 2002) e com história de violência de gênero na família, ou seja, presenciou ou conviveu com a violência de maneira muito próxima (Durand, 2006; Castro, Ruiz, 2004; Menezes et al., 2003). As vítimas possuem vida conjugal mais longa, maior número de filhos e também de abortos (Kronbauer, Meneghel, 2005).

A maioria das mulheres agredidas é negra ou parda (Lee et al., 2002; Galvão, 2002). Num estudo realizado em Campinas, porém, a maioria $(69,9 \%)$ das mulheres agredidas era da cor branca (Oshikata et al., 2005).

A situação socioeconômica está ligada à freqüência e à resposta das mulheres à violência (Alvarado, Erazo, 2002). Mulheres com atividades ligadas ao emprego doméstico ou limpeza, tais como donas-de-casa, faxineiras, copeiras, serventes e empregadas domésticas, podem ter maior propensão a serem vítimas da violência (Meneghel et al., 2000). Em geral, provêm de classes sociais menos favorecidas (Kronbauer, Meneghel, 2005; Nasir, Hyder, 2003) ou possuem um perfil semelhante ao da exclusão social (Andrade, 2003). Alguns autores encontraram associação significativa entre o fato de a mulher ter renda própria relativamente alta e a não-ocorrência de episódios de violência (Galvão, 2002).

Em relação aos instrumentos utilizados na agressão física, em sua maioria, o agressor usa a mão (arranhões, socos, empurrões, puxões de cabelo, entre outros) e o objeto mais próximo para perpetrar a violência (Kronbauer, Meneghel, 2005; Jong, 2000). Estudo realizado no Estado de 
São Paulo constatou que as regiões do corpo mais atingidas pelas agressões são: face (28,0\%); cabeça e pescoço (26,6\%); membros superiores $(25,2 \%)$ e membros inferiores $(16,8 \%)$. Costas, barriga, tronco, nádegas e outras regiões vêm em seguida (Schraiber et al., 2002; Garbin et al., 2006). Achados relacionados às regiões citadas como as mais atingidas - especialmente, face, pescoço e braços - são compatíveis com os resultados de outros estudos brasileiros (Jong, 2000; Garbin et al., 2006). Além de um comportamento de defesa com os braços, podem indicar o caráter simbólico de humilhação e de agressão à dignidade da pessoa humana de que se revestem os atos de agressão à face; deixando visível a agressão e prejudicando a beleza, um atributo valorizado pela sociedade (Jong, 2000).

\subsection{VIOLÊNCIA DE GÊNERO E AGRAVOS À SAÚDE}

A violência de gênero é um fenômeno social que tem graves conseqüências para a saúde pública e os direitos humanos das mulheres. Segundo o Banco Mundial e o Banco Interamericano de Desenvolvimento, o estupro e a violência doméstica são causas importantes de incapacidade e morte de mulheres em idade produtiva. Na América Latina e Caribe, a violência doméstica atinge entre $25 \%$ e $50 \%$ das mulheres (IPAS Brasil, 2005).

Informações epidemiológicas de morbidade e mortalidade podem deixar ocultos alguns fenômenos sobre a violência. Alguns deles têm maior prevalência em um dos sexos, como por exemplo: as mulheres estão expostas a condições extremas de privação de recursos para desempenhar sua dupla ou tripla jornada diária em muitas sociedades; ou os homens expressam mortalidade superior por acidentes e violência ao longo de toda vida - o que está estreitamente associado com atitudes e condutas 
masculinas estereotipadas. Os processos que estão subjacentes à má saúde de mulheres e de homens vão além das condições epidemiológicas, e as forças sociais e históricas geram desvantagens de gênero no desfrutar da saúde, passando do âmbito individual ao coletivo (Estrada, 2005).

A diferença de poder entre os gêneros se observa, por exemplo, na deterioração da saúde física e mental da mulher devida ao trauma da violência que ocorre no lar, podendo resultar em mortes prematuras (Hardy, Jiménez, 2001). Os episódios, por sua vez, podem tornar-se mais graves com o passar do tempo (Vaiz Bonifaz, Nakano, 2004; Mota, 2004). Isso porque a principal característica desse tipo de violência é a rotinização e a incidência sobre as mesmas pessoas, tornando-se habitual (Saffioti, 2004).

Violência sexual pode resultar em doença inflamatória pélvica, hepatite B, sífilis e infecção por HPV (papilomavírus humano) detectada na citologia do colo (Oshikata et al., 2005).

"As mulheres que vivem uma relação violenta tendem a apresentar problemas de saúde de diversos tipos, problemas mentais, depressão e até propensão ao suicídio. Elas também fazem menos Papanicolaou, fazem menos sexo seguro" (D'Oliveira, s/d).

Em um estudo brasileiro realizado com 157 mulheres, para investigar a incidência da violência conjugal sofrida por mulheres e seu conhecimento sobre medidas preventivas de DST/HIV, 86\% referiram sofrer violência conjugal. Do total, $94,90 \%$ já ouviram falar sobre doenças sexualmente transmissíveis (DST) e infecção pelo HIV (vírus da imunodeficiência humana adquirida). Há que se considerar que na violência conjugal, as relações de gênero influenciam inclusive na adesão às medidas preventivas de DST/HIV, sendo um processo social cristalizado por relações desiguais entre os gêneros (Diniz et al., 2003). Tal fato pode agravar sobremaneira a situação de saúde das envolvidas.

Na relação entre saúde e abuso, mulheres apresentam estresse como efeito indireto do abuso (Sutherland, 2002). Freqüentemente também apresentam quadro sugestivo de depressão clínica, sintomas de ansiedade e insônia, pensamento suicida e uso de ansiolítico após as agressões (Adeodato et al., 2005). Ocorre alto consumo de medicação de uso 
controlado e contínuo entre as usuárias dos serviços de saúde, sendo que $63 \%$ delas são consumidoras de ansiolíticos e antidepressivos (Alves, Coura Filho, 2001). Há várias outras conseqüências possíveis, tais como perda de memória, confusão mental, baixa auto-estima, falta de desejo sexual, fraturas, abortos, infarto, depressão e suicídio (Kronbauer, Meneghel, 2005; Tavares, 2000). Estudo realizado na Costa Rica mostrou que $47 \%$ das mulheres vítimas de violência já haviam pensado em suicídio e $48 \%$ haviam deixado o lar onde viviam por medo de morrer e a iminência da morte faz parte da vida cotidiana de $58 \%$ delas (Carcedo Cabanas, Sagot Rodriguez, 2002).

Em muitas sociedades tradicionais, é difícil perceber a mulher como geradora de cultura. Sua função de reprodutora a aproxima mais da natureza do que da ordem cultural (Noronha, Daltro, 1991). A resultante disso é que, no período gestacional, elas sofrem o impacto da violência e ficam mais vulneráveis à sua ocorrência. Em países desenvolvidos, os índices de violência contra mulheres grávidas variam de $4 \%$ a $29 \%$ revelando que a violência contra as gestantes constitui uma questão de saúde global que exige a implementação de melhores estratégias preventivas, principalmente para os casos de gravidez não planejada (Nasir, Hyder, 2003).

A gravidade e a prevalência da violência entre mulheres grávidas não muda significativamente antes e depois da gravidez, porém a violência psicológica é mais freqüente em relação à física e sexual (Castro, Ruiz, 2004). A prevalência de violência física antes da gestação fica em torno de $13 \%$ e, depois da gravidez, de $7 \%$. Cessa em $43 \%$ dos casos, diminui em $27 \%$ e aumenta em $11 \%$ dos casos após o início da gestação (Menezes et al., 2003). Kronbauer e Meneghel (2005) registram cifra de violência na gestação contra mulheres com companheiros em torno de 17\%, enquanto outras estimativas da literatura apontam-nas em torno de 10\% (Kronbauer, Meneghel, 2005). As crianças de mães expostas à violência durante a gestação apresentam aproximadamente 450 gramas menos ao nascerem do que as das mães não-expostas. As mães agredidas, por outro lado, ganham 
peso (Nuñez-Rivas et al., 2003).

Estudo realizado com mulheres usuárias de 14 serviços públicos de saúde no Brasil revelou que "em geral, as mulheres vítimas de agressão durante a gravidez sofrem os piores tipos de violência na vida". Quase um quarto das entrevistadas havia sofrido violência física grave por parceiro íntimo, incluindo agressões como socos e queimaduras, ameaça ou uso de arma. A pesquisa revelou ainda que $60 \%$ delas já haviam sofrido algum tipo de violência (física, sexual ou psicológica) pelo parceiro. Cerca de $20 \%$ das entrevistadas afirmaram terem sido agredidas durante a gravidez. Os desencadeadores da agressão foram a gravidez não planejada, a dúvida em relação à paternidade e a visão de que a chegada de um filho obriga ao estabelecimento de um compromisso entre o casal. Com isso, cria-se uma situação de dependência em que o homem enxerga a mulher como submissa - uma visão que tende a se acentuar com a gravidez. Além disso, os homens agressores não se sentem aptos a serem pais (Durand, 2006).

Em estudo realizado com mulheres na faixa etária de 20 a 24 anos que se tornaram mães na adolescência, os homens agiam mais livremente, mantendo relações extraconjugais e agredindo suas mulheres em casa (Trindade, 2005). A gravidez precoce aparece também como fator de risco para a violência de gênero (Trindade, 2005; Flores Sullca, 2004; NúnezRivas et al., 2003).

A alta freqüência da violência perpetrada pelo homem, conforme demonstrado pelos estudos, faz da violência de gênero um fenômeno invisível, porque essa freqüência a torna comum, assim como por ser dirigida à mulher, tendo por base a submissão feminina. Essas situações são desvalorizadas enquanto problemas sociais ou de saúde. Os familiares, vizinhos, colegas ou a comunidade - incluindo-se aí os profissionais de saúde ou de outros serviços de assistência - e até as próprias vítimas de violência, nenhum deles reconhece a situação como uma transgressão aos direitos das mulheres e como um contexto instaurador de dano à saúde. Assim sendo, a visibilidade exige conhecimento e propostas de solução que 
envolvem tanto estudos, como perspectivas variadas, "significa não só ver e compreender, mas também fazer ver" (Schraiber et al., 2005:36).

Profissionais da saúde, em particular médicos da emergência, ginecologistas, obstetras e parteiras estão na linha de frente na identificação da vítima de violência, como provedores de cuidados (Lebas et al., 2002). A equipe de saúde deve estar articulada para a detecção dos casos de violência e assistência prestada às mulheres. A não-percepção dessa violência se deve a várias circunstâncias, tais como despreparo, desinteresse, falta de tempo para escutar os pacientes durante os atendimentos e ater-se somente às lesões físicas (Garbin et al., 2006).

As mulheres que vivenciam relações violentas de gênero não as apresentam ao serviço de saúde como sua principal queixa e sim seus efeitos, pois quando procuram atendimento, o fazem pelos agravos decorrentes da violência. Sem apresentar como queixa o ato violento, que muitas vezes é o gerador do atendimento, a mulher interioriza as agressões e as manifesta em sintomas clínicos, indecifráveis pelo profissional que, em geral, não encontra um diagnóstico compatível com o problema apresentado (Silva, 2003).

Valores e normas culturais servem para reforçar práticas abusivas contra as mulheres e os profissionais são primeiramente mulheres e homens que, como tal, experienciam os mesmos valores socioculturais das pacientes que tratam e aconselham (Kim, Motsei, 2002). Em se tratando de mulheres, as profissionais também podem estar sujeitas às mesmas violações e abusos que afetam as parturientes. Muitas vezes, essas profissionais, embora sensíveis e conhecedoras das necessidades das mulheres, raramente identificam a ocorrência de violência, uma vez que não fazem perguntas se não suspeitam disso. Assim, a violência permanece escondida, a menos que essa questão seja incluída como rotina na assistência - no caso das mulheres grávidas, no programa de pré-natal (Edin, Hogberg, 2002).

Cavalcanti et al. (2006) investigaram as representações sociais de profissionais de saúde da assistência pré-natal sobre violência sexual contra 
a mulher e mostraram que a reprodução cultural de estereótipos vem solidificando percepções sexistas e reducionistas contra as mulheres. Concluem que a compreensão, pelos profissionais, a respeito das relações de gênero poderia permitir-lhes uma visão mais crítica da agressão sexual contra a mulher, vinculando a violência à distribuição desigual do poder e às relações assimétricas que se estabelecem entre homens e mulheres (Cavalcanti et al. 2006).

\subsection{VIOLÊNCIA E ATENÇÃO À SAÚDE NO PROGRAMA DE SAÚDE DA FAMÍLIA}

A atenção básica constitui o primeiro nível da atenção à saúde no Sistema Único de Saúde (SUS), compreendendo um conjunto de ações de caráter individual e coletivo, que englobam a promoção da saúde, a prevenção de agravos, o tratamento, a reabilitação e manutenção da saúde. O Programa de Saúde da Família (PSF), estratégia priorizada pelo Ministério da Saúde para organizar a atenção básica, tem como principal desafio promover a reorientação das práticas e ações de saúde de forma integral e contínua, levando-as para mais perto da família (Brasil, 2004).

$\mathrm{O}$ atendimento no PSF é prestado pelos profissionais das equipes de saúde da família (médicos, enfermeiros, auxiliares de enfermagem, agentes comunitários de saúde e outros) na unidade de saúde ou nos domicílios. Essas equipes são responsáveis pelo acompanhamento de um número definido de famílias, localizadas em uma área geográfica delimitada. A responsabilidade pelo acompanhamento das famílias faz com que as equipes ultrapassem os limites classicamente definidos para a atenção básica no Brasil, especialmente no contexto do SUS. Para o Ministério da Saúde, o trabalho desenvolvido pelas equipes é o elemento-chave para a busca permanente de comunicação e troca de experiências e 
conhecimentos entre os integrantes da equipe e desses com o saber popular do Agente Comunitário de Saúde (Brasil, 2004).

"Esta nova estratégia de atenção visa um atendimento diferenciado com vínculos de compromisso e co-responsabilidade sobre a saúde" (Santos, 2003:35). O convívio entre a equipe e a população atendida e acompanhada cria vínculos facilitadores de identificação. A aproximação entre os profissionais de saúde e a clientela das áreas de abrangência expõe problemas que anteriormente permaneciam na desinformação dos serviços. Além disso, a criação de vínculos pode proporcionar um atendimento contínuo e humanizado. De outra parte, a estreita relação entre profissionais e usuários de serviços que o programa cria, desde 0 diagnóstico da necessidade em saúde, passando pelo trabalho com a comunidade, até as visitas realizadas pelos agentes comunitários e demais profissionais, favorece vínculos e empatias necessários à abordagem de um tema tão sensível e complexo como a violência doméstica (Batista, 2003).

O PSF traz também uma outra vantagem, organizativa e prática, relativa ao vínculo profissional-clientela no cotidiano do trabalho que facilita a abordagem da violência de gênero como problema de saúde: na proposta do PSF, as famílias e pessoas atendidas pelos profissionais de saúde são sempre as mesmas, o que permite um olhar específico e reiterado a cada uma delas. Isso, conseqüentemente, resulta na percepção da recorrência de alguns acontecimentos como os eventos violentos, por exemplo.

Alguns estudos sobre violência de gênero já foram realizados especificamente no âmbito do PSF (Oliveira, 2005; Batista, 2003; Santos, 2003). Batista (2003) assinalou que a prevalência da violência de gênero entre as famílias atendidas pelo PSF na zona Leste do município de São Paulo é alta.

Outro estudo sobre avaliação do PSF, realizado em Ribeirão Preto em 2000, constatou que existe correlação entre violência e a presença de sinais de alerta como depressão, indicando a necessidade de atenção do profissional para a possibilidade da ocorrência de violência doméstica, para além da averiguação dos sinais ou sintomas. A baixa taxa diagnóstica se 
deve, segundo a autora, à dificuldade de diagnosticar e de registrar a violência doméstica nos prontuários. Entre os prontuários registrando casos de agressão, 68,75\% deles foram achados casuais (Santos, 2003).

O silêncio das mulheres e a invisibilidade dos serviços ocasionam o desconhecimento da real magnitude da violência de gênero e dos seus efeitos na qualidade de vida ou no perfil de morbidade de uma população, ou mesmo no padrão de uso que se pode correlacionar com esse evento (Schraiber, D'Oliveira, 2003). As dificuldades em atender as mulheres vítimas de violência sexual expressam o quanto a ciência construída e disseminada nas escolas ainda reflete uma perspectiva masculina. A mulher ainda continua sendo invisível na produção e reprodução.

Essa visão estereotipada de homem e mulher se caracteriza também no atendimento em saúde realizado no âmbito domiciliar em Belo Horizonte. Em relação à assistência prestada no PSF à violência de gênero, os profissionais que integram as equipes definem sua atuação como de "impotência paralisante" que consideram como um reflexo da falta de organização do serviço para este fim. No atendimento a mulheres vítimas de violência sexual, falta preparo para trabalharem com um problema desta natureza e com tamanha complexidade (Oliveira, 2005).

Para Batista (2003), o sentimento de impotência percebido em todos os profissionais que trabalham com esses casos é presente, e a possibilidade de escuta e a diminuição da invisibilidade também existem, ao menos teoricamente. Muitos casos de violência podem não ser acolhidos ou assistidos, perdendo-se oportunidades de atendimento e a impotência dos profissionais pode estar associada à vitimização. O acolhimento, por sua vez, depende da disponibilidade pessoal de cada profissional.

Para D'Oliveira,

"se a introdução de um tema tradicional do feminismo no campo da assistência à saúde traz um grande aumento de legitimidade para a questão, também encerra novos dilemas, decorrentes das conseqüências práticas para o trabalho em saúde da abordagem de tema tão eminentemente privado e relacional" (D'Oliveira, 2000:2). 
A proximidade maior entre a equipe de saúde e as mulheres da coletividade não garante a habilidade e a visibilidade da violência para o profissional sobre a violência, assim como a vocalização da queixa pela mulher, inclusive no PSF, porque o reconhecimento dependerá da sensibilidade, subjetividade e da construção de gênero de cada um. Contudo, a assistência é intencionada para responder assertivamente, pois ela tem como objetivo final responder às necessidades em saúde. No caso da violência de gênero, essas necessidades vão além do atendimento primário, se estendem a outros serviços para auxiliar a mulher no enfrentamento do problema (Schraiber, D'Oliveira, 1999).

Contrariamente a essa intenção, no entanto, a assistência prestada não leva em conta a assimetria nas relações entre homens e mulheres construída socialmente. Especificamente em casos que envolvem a violência de gênero, o atendimento é centrado no aspecto biológico - nas condições físicas apresentadas - ignorando os atributos sociais do sexo biológico. Possivelmente, contribui para isso o fato dessas mulheres apresentarem demandas recorrentes, sofrerem agressões sucessivas e serem desacreditadas pelos profissionais de saúde. Isso ocorre porque a ideologia vigente não considera que as mulheres sofram violência em decorrência da assimetria de gênero, mas por outras causas que, em geral, estariam situadas exclusivamente na dimensão individual.

Portanto, a depender de cada profissional de saúde e de seus juízos pessoais que envolvem emoções e valores, sua prática está muitas vezes impregnada de preconceitos, não correspondendo, desta forma, às necessidades apresentadas pelas mulheres. Assim, a resposta do serviço às demandas apresentadas pelas mulheres pode ser determinante para a próxima procura da usuária e a resolutividade do caso pois, ao contrário do que parece ao senso comum, uma boa parte das pessoas que vivem em situação de violência já tomou diversas decisões e ações no sentido de rompê-la, embora estas muitas vezes não tenham sido bem sucedidas nas instituições às quais recorreram (Schraiber, D'Oliveira, s/d). 
Assim, partindo do pressuposto de que os profissionais do PSF não conseguem identificar as desigualdades que estabelecem entre a clientela feminina e a masculina, no que se refere à violência de gênero, o atendimento compromete a assistência às mulheres envolvidas.

Os relatos do início deste trabalho evidenciaram que a violência de gênero é responsável por diversos agravos à saúde de muitas mulheres, mas para que os serviços de saúde possam desenvolver ações e intervenções mais efetivas, e não apenas atenuar o problema, atendendo unicamente o aspecto físico, é importante identificar a visão de mundo de cada profissional a respeito da construção social de mulheres e de homens (gênero) e da violência de gênero. Para Fonseca, Egry e Bertolozzi (2006: 20), "a visão de mundo nada mais é que um sistema de pontos de vista sobre a realidade que permite ao homem elaborar uma atitude perante esta realidade". Essa visão encontra-se na base da compreensão e ação do homem perante a realidade, ela não é atemporal e vincula-se ao momento histórico da sociedade que Ihe origina (Fonseca, Egry, Bertolozzi, 2006).

Nesse sentido, qualquer proposta de qualificação das equipes de saúde da família a ser implementada nos serviços de saúde deve considerar seu contexto cultural. Levando-se em conta que a construção de gênero dos profissionais do PSF, em geral, se dá numa perspectiva androcêntrica - a hegemônica na nossa sociedade - é importante saber o que pensam os profissionais das equipes de saúde sobre as relações de gênero e a violência de gênero. Assim, o objeto de estudo do presente trabalho são as concepções sobre violência de gênero dos profissionais que integram a equipe do PSF. 


\section{OBJETIVOS}

- Conhecer e analisar à luz de gênero a visão dos profissionais das equipes de Saúde da Família acerca de homem e mulher.

- Identificar e analisar, à luz de gênero, a percepção dos membros das equipes de saúde da família sobre a violência de gênero.

- Detectar e analisar, à luz de gênero, as contradições que permeiam as concepções dos profissionais em relação à mulher, homem e violência de gênero. 


\section{MÉTODO}

\subsection{REFERENCIAL TEÓRICO}

\subsubsection{Gênero e violência de gênero}

Certamente, o olhar crítico sobre a maneira como nos relacionamos é que possibilita apreender o conceito de gênero. Quando realizamos o exercício da percepção para identificar o detentor do poder, é possível observar, nas mais diversas relações, as hierarquias que estão presentes. A hierarquia nada mais é do que uma medida do grau de autoridade, numa classificação, crescente ou decrescente, segundo uma escala baseada no valor, onde cada indivíduo, no momento em que a percebe, encontra seu lugar na relação.

No caso da hierarquia de gênero, a relação assimétrica é a estabelecida entre homens e mulheres, mulheres e mulheres, homens e homens propositalmente. Entre mulheres e homens, se dá em ordem decrescente, embora em determinadas circunstâncias, mulheres e homens vivenciem situações em que isso não se estabelece. Se isto é verdadeiro na dimensão singular da realidade objetiva - a relativa aos sujeitos sociais -, o mesmo não se pode dizer no que ocorre nas dimensões particular (dos grupos sociais) e estrutural (dos processos mais gerais da sociedade e da sua estrutura jurídico-político-ideológica).

A categoria gênero é relacional. Isso quer dizer que, por um lado, os gêneros se definem na relação com o outro e, por outro, sendo um aspecto das relações sociais de poder e de subjetivação, gênero se articula com outros tipos de relações sociais -geração, raça, etnia, classe, profissão, sexualidade - de maneiras cada vez mais diversas. 
O conceito de gênero, no Brasil, Estados Unidos, França, Inglaterra, dentre outros, surgiu na década de 1970, fruto do trabalho de estudiosas feministas que iniciaram o debate sobre gênero para ressaltar a construção e a organização social da relação entre os sexos. No Brasil, o reflexo desse movimento apareceu nos anos 80 , quando foram incrementados os estudos sobre mulheres e relações de gênero.

No presente estudo, para entender como as relações entre mulheres e homens, mulheres e mulheres, e homens e homens acontecem, será utilizado o conceito de gênero da historiadora norte-americana Joan Scott. Para ela,

\footnotetext{
"o núcleo essencial da definição baseia-se na conexão integral entre duas proposições: gênero é um elemento constitutivo de relações sociais baseado nas diferenças percebidas entre os sexos, e o gênero é uma forma primeira de significar as relações de poder" (Scott, 1995:11).
}

A primeira parte - como elemento constitutivo das relações sociais envolve quatro componentes: os símbolos culturalmente disponíveis, os conceitos normativos expressos nas doutrinas religiosas, educativas, científicas, políticas e/ou jurídicas, a organização social e suas instituições e a construção das identidades subjetivas. Para Scott, nenhum dos elementos opera sem os outros, entretanto não atuam simultaneamente como se fossem reflexos do outro. Sua proposta tem como objetivo clarificar e especificar como é preciso pensar o efeito de gênero nas relações sociais e institucionais, pois, para ela, essa reflexão nem sempre é realizada de maneira precisa e sistemática (Scott, 1995).

Gênero é um conceito cultural vinculado à forma como a sociedade constrói as diferenças sexuais, atribuindo status diferente a homens e mulheres. Enquanto instrumento analítico conduziria à revisão de paradigmas orientados no sentido de subordinação das mulheres pelos homens. Para Scott, é preciso desconstruir as oposições binárias, pois mulheres e homens não são pólos opostos que se relacionam dentro de uma lógica invariável de dominação-submissão. A desconstrução dos pólos implicaria observar que um contém o outro e vice-versa (Scott, 1995). 
Para Louro (1997) implicaria também perceber que cada um desses pólos é internamente fragmentado e dividido, uma vez que não existe a mulher ou o homem, mas diferentes formas de vivenciar a feminilidade e masculinidade.

Além disso, o conceito propicia visualizar que as relações de dominação-subordinação repetem-se entre e dentro das classes sociais, nos grupos étnicos e entre gerações. Conseqüentemente, na nossa sociedade o valor é hierarquizado de tal maneira que, sob certos pontos de vista podemos afirmar quem vale mais: no gênero, o homem; nas etnias, o branco, do ponto de vista econômico, os ricos, no que tange à geração, o adulto.

Essa maneira de indicar as construções sociais, baseada nos saberes, nas instituições, estruturas e ações geradas pela cultura, afastando justificativas biológicas, resulta numa categoria social imposta sobre um corpo sexuado. Porém, como a construção de gênero é histórica e se faz continuamente, as relações entre mulheres e homens, os discursos e as representações dessas relações estão constantemente se transformando.

A segunda parte do conceito de gênero de Scott (1995) corresponde à teorização do gênero, que se refere ao poder na assimetria das relações entre homens e mulheres. Tal poder é articulado e sua perspectiva aproxima-se do conceito de Foucault:

"poder deve ser algo que circula, ou melhor, como algo que só funciona em cadeia. Nunca está localizado aqui e ali, nunca está nas mãos de alguns, nunca é apropriado como uma riqueza ou um bem. Nas suas malhas os indivíduos não só circulam, mas estão sempre em posição de exercer este poder e de sofrer sua ação" (Foucault, 2001:183).

Assim, o poder é circunstancial; ora encontra-se em um, ora em outro, contudo, pressupõe-se que as mulheres, em determinadas situações, possuem esse poder relacional, mas, em relacionamentos violentos, nem sempre ele é suficiente para sustar a dominação ou a violência que sofrem, sendo possível pensar em diferentes processos de subjetivação e 
singularização vivenciados por homens e mulheres (Araújo, Martins, Santos, 2004).

"Ninguém nasce mulher: torna-se mulher" (Beauvoir, 1960:9). A célebre frase de Simone de Beauvoir, na sua acepção, descreve o poder da sociedade na construção social da identidade de gênero. Da mesma maneira, ninguém nasce homem, torna-se homem. Assim como a feminilidade, a masculinidade de um novo ser começa a ser construída antes da gravidez e continua depois do nascimento (Hardy, Jiménez, 2001).

Assim é que pesquisadores sobre violência afirmam que os aspectos biológicos têm um papel mínimo na explicação do comportamento violento. Rapazes são ensinados a expressar raiva e agredir os outros, mas não para expressar tristeza e remorso. Estudos mostram que ambos, meninas e rapazes, usam a violência: eles mais propensos a usar agressão física (bater, chutar) e elas, as agressões indiretas, mentindo, ignorando alguém ou rejeitando outros membros do grupo social (Barker, Nascimento, 2001).

A violência de gênero tem sua origem nas relações que se estabelecem entre o exercício de poder do homem sobre a mulher e são relações que se dão de forma assimétrica. Em sendo construções sociais, podem potencialmente permitir modificações.

Para Teles e Melo "o conceito de violência de gênero deve ser entendido como uma relação de poder de dominação do homem e de submissão da mulher" (Teles, Melo, 2002:18). Essa violência, para as autoras, originou-se na discriminação histórica das mulheres, num processo de construção e consolidação de medidas e ações explícitas e implícitas, visando à sua submissão. A força bruta, inicialmente, forjou o controle masculino sobre as mulheres e gradativamente foram introduzidos novos métodos e novas formas de dominação masculina: as leis, a cultura, a religião, a filosofia, a ciência, a política.

Trata-se de um conceito capaz de apreender que as condições da dimensão relacional estão intrínsecas, ligadas desde o nascimento, ou mesmo antes do nascimento, na preparação do ambiente pelo núcleo familiar. Essa nova perspectiva de abordagem abriu possibilidades de 
discussão a respeito da vitimização, que impregnava os primeiros estudos sobre a violência de gênero. O que se acredita hoje é que, ao invés de vítimas, as mulheres que estão inseridas em relações de gênero violentas, de certa maneira, acabam se tornando cúmplices do agressor, numa relação dialética de pólos contrários indissolúveis, até que consigam desenvolver mecanismo de ruptura deste tipo de relação.

A disseminação dos estudos de gênero no Brasil recolocou gênero como elemento preponderante para a compreensão dessa violência, o que vem influenciando não só a produção de estudos específicos, como também implementar ações e políticas sociais de enfrentamento dos diferentes aspectos do fenômeno (Araújo, Martins, Santos, 2004).

A violência de gênero sempre existiu no Brasil, mas abrange também outros países. É um fenômeno que ocorre independentemente da riqueza e do grau de desenvolvimento da nação, do nível de escolaridade dos envolvidos, do tipo de cultura, ocidental e oriental, da religião dominante etc. Para Miller, pela violência de gênero é possível medir a violação dos direitos humanos, medir o grau pelo qual uma sociedade é governada pela agressividade, dominada pela rivalidade e regida pela força (Miller, 2000). 


\subsection{PROCEDIMENTOS METODOLÓGICOS}

\subsubsection{Cenário do estudo}

A cidade de Araraquara localiza-se na região central do Estado de São Paulo, com estimativa populacional de 194.401 habitantes (Prefeitura de Araraquara, 2006). Em 2000, havia 182.471 habitantes, sendo 88.742 homens e 93.729 mulheres. O perímetro urbano concentrava 173.569 habitantes e a área rural 8.902 habitantes. A taxa de alfabetização da população residente de 10 anos ou mais de idade era de 95,2\%. Possuía 40 estabelecimentos de ensino pré-escolar, 49 estabelecimentos de ensino fundamental e 17 de ensino médio. Além disso, possuía 04 hospitais (Prefeitura de Araraquara, 2006).

A cidade pode ser considerada uma das mais progressistas cidades do interior do Estado, pois sua população, com alto poder aquisitivo, possui uma renda per capita de $R \$ 441,87$, tornando-a um grande mercado consumidor do Brasil.

Em relação à saúde, a Secretaria Municipal de Saúde de Araraquara passou por um processo de reorganização em 2001, no sentido de adequar sua estrutura gerencial para fazer frente às demandas da população e à orientação política da nova administração para esta área (Prefeitura de Araraquara, 2006).

\subsubsection{Sujeitos da pesquisa e coleta de dados}

Participaram do estudo 95 profissionais de 12 equipes da atenção básica à saúde do município de Araraquara, no Estado de São Paulo, a 
maioria pertencente ao Programa de Saúde da Família (PSF). Os dados foram coletados durante Oficinas de Trabalho, os participantes foram distribuídos em três grupos, contendo profissionais de diferentes Unidades Básicas de Saúde (UBS) ou equipes do PSF; o grupo 1 foi formado por 25 participantes, o grupo 2, por 36 e o grupo 3 por 34 . Cada oficina foi realizada em três períodos de quatro horas, totalizando 12 horas com cada grupo.

Quanto à função e escolaridade, os participantes apresentavam o seguinte perfil:

- 81 (85,26\%) eram agentes de saúde - 2 deles (2,47\%) com nível superior, $8(9,87 \%)$ com nível superior incompleto, 61 (75, 31\%) com ensino médio e $10(12,35 \%)$ com ensino médio incompleto

- $7(7,36 \%)$ eram enfermeiras com nível superior

- $3(3,15 \%)$ eram agentes de enfermagem com ensino médio completo.

Os profissionais pertenciam às equipes do PSF do Jardim leda, Jardim das Hortências, Águas do Paiol, Vale do Sol, Bueno de Andrade, Assentamento Bela Vista, Marivan, Maria Luiza, Pinheiros-Jardim Pinheiros, PACS (Programa de Agentes Comunitários de Saúde) Laranjeiras-Parque Laranjeiras, PACS Parque São Pedro, CMS Parque São Paulo.

Além dos profissionais das equipes do PSF, participaram também 1 psicóloga do Centro de Referência da Mulher Heleieth Saffioti; 1 enfermeira da Prefeitura Municipal de Araraquara; 1 enfermeira do Serviço Especial de Saúde de Araraquara e 1 enfermeira do Hospital Municipal Gota de Leite.

A coleta de dados foi realizada durante uma Oficina de Construção Coletiva, que aconteceu durante uma semana, sob a coordenação da Professora Doutora Rosa Maria Godoy Serpa da Fonseca. O formato foi, especificamente, o de oficina de gênero em que se procurou enfocar os conhecimentos e a postura dos profissionais de saúde em relação à violência de gênero.

Um dos motivos pelo qual foi utilizada a Oficina de Construção Coletiva para a coleta dos dados foi porque a experiência acumulada do 
Grupo de Pesquisa "Gênero, saúde e enfermagem" demonstra que as características deste método o tornam opção privilegiada em termos de aliar as dimensões educativa e investigativa, nesta última, muito além da mera coleção de depoimentos. Desta forma, eticamente, configura-se no retorno imediato aos participantes de pelo menos uma parte dos benefícios sociais gerados pela pesquisa, qual seja a ampliação da crítica a respeito dos temas levantados (Fonseca, 2006).

As características do método são basicamente: horizontalidade e eqüidade de poder entre os sujeitos e entre estes e a coordenação; estabelecimento de um clima de cooperação, amizade e solidariedade entre os participantes oriundos do tipo de estratégias participativas utilizadas, facilitadoras e estimuladoras da participação de todos, em eqüidade de poder; possibilidade de construção coletiva do conhecimento a partir da contribuição de cada um com a experiência que porta e com os posicionamentos que é capaz de defender, posto que baseado na vivência; possibilidade de captação da realidade a partir da experiência prática dos sujeitos, relatada a partir de casos reais e referentes à historicidade do tema abordado (Fonseca, Amaral, Mello, 2007).

O segundo motivo foi porque na ocasião da coleta dos dados, por iniciativa de alguns órgãos da Prefeitura Municipal de Araraquara, foram desenvolvidas várias atividades durante o mês de novembro, que inclui, no dia 25, o Dia Internacional da Não violência contra as Mulheres.

O programa voltado para estes profissionais abordou a violência de gênero como fenômeno social e incluiu uma Oficina visando à identificação do conteúdo ideológico das práticas do PSF voltadas para mulheres envolvidas em relações de gênero violentas e à introdução da categoria como elemento fundante da assistência.

Os dados utilizados nesta pesquisa referem-se à totalidade da primeira sessão que abordou o tema "Homem e mulher no mesmo barco social" e à metade da segunda sessão, denominada "A violência e as 
práticas em saúde para as mulheres em situação de violência: determinantes e conseqüentes”, conforme a seguinte programação.

Sessão 1 - "Homem e mulher no mesmo barco social"

\section{Objetivos específicos:}

Explicitar e analisar a visão de mulher e de homem dos participantes acerca de mulher, de homem, das relações que se estabelecem entre eles e do lugar social que ocupam.

Refletir sobre o processo histórico de construção da masculinidade e da feminilidade na sociedade brasileira

\begin{tabular}{|c|c|c|}
\hline Momento & Conteúdo & Estratégia/ Material \\
\hline $\begin{array}{l}\text { Introdução } \\
30 \text { min }\end{array}$ & $\begin{array}{l}\text { 1. Elaboração do crachá } \\
\text { 2. Apresentação das coordenadoras } \\
\text { 3. Apresentação dos participantes } \\
\text { - Prazer em conhecer } \\
\text { - Painel } \\
\text { "O PSF Araraquara somos nós" } \\
\text { 4. Apresentação da oficina: } \\
\text { finalidades, objetivos e explicação das } \\
\text { atividades. } \\
\text { 5. Pesquisa - finalidades, objetivos, } \\
\text { Termo de Consentimento Livre e } \\
\text { Esclarecido. }\end{array}$ & $\begin{array}{l}\text { Apresentação dos participantes. } \\
\text { Questionário - nome, unidade de } \\
\text { procedência, formação } \\
\text { profissional. } \\
\text { Material: impressos, folder sobre } \\
\text { a oficina, canetas, crachás de } \\
\text { identificação; papel sulfite de } \\
\text { várias cores para o painel. }\end{array}$ \\
\hline $\begin{array}{l}\text { Aquecimento } \\
10 \mathrm{~min}\end{array}$ & $\begin{array}{l}\text { "Algo sobre o chocolate" } \\
\text { Divisão da classe em } 4 \text { grupos }\end{array}$ & $\begin{array}{l}\text { Chocolates de } 4 \text { cores } \\
\text { diferentes }\end{array}$ \\
\hline $\begin{array}{l}\text { Desenvolvimento } \\
60 \mathrm{~min}\end{array}$ & $\begin{array}{l}\text { Trabalho nos grupos } \\
\text { "Homem e mulher no mesmo barco" } \\
\text { Quem sou eu, quem é você? Onde } \\
\text { estamos nós? } \\
\text { (Representação individual sobre o } \\
\text { homem, a mulher e as relações entre } \\
\text { eles) } \\
\text { Grupos } 1 \text { e } 2 \text { - escultura em tecido } \\
\text { Grupos } 3 \text { e } 4 \text { - escultura em papel } \\
\text { Trabalho em plenária } \\
\text { "Homem e mulher no mesmo barco } \\
\text { social" (exposição sobre os barcos } \\
\text { contendo as representações grupais) }\end{array}$ & $\begin{array}{l}\text { Roteiro } \\
\text { Retalhos de tecidos e adereços } \\
\text { de costura; papel colorido, cola, } \\
\text { tesoura, cartolina. } \\
\text { Barco grande (dobradura) }\end{array}$ \\
\hline $\begin{array}{l}\text { Síntese } \\
50 \text { min }\end{array}$ & $\begin{array}{l}\text { Homem e mulher no mesmo barco } \\
\text { social }\end{array}$ & $\begin{array}{l}\text { Exposição dialogada } \\
\text { Material - computador, data- } \\
\text { show }\end{array}$ \\
\hline $\begin{array}{l}\text { Encerramento } \\
10 \mathrm{~min}\end{array}$ & Para casa - trazer sucata & \\
\hline
\end{tabular}

Fonte: Fonseca, RMGS Oficina de Construção Coletiva "Mulher e violência: reconstruindo a assistência no âmbito do PSF" - Programação. Araraquara, nov. 2005. 
Sessão 2 - "A violência e as práticas em saúde para as mulheres em situação de violência: determinantes e conseqüentes"

\section{Objetivos específicos:}

Identificar e refletir sobre a percepção dos profissionais que atuam nas equipes de saúde da família sobre a violência contra a mulher a sobre as práticas correspondentes desenvolvidas no âmbito do PSF

- Ampliar a visão dos profissionais acerca da violência contra a mulher como problema a ser enfrentado no conjunto das ações do PSF

\begin{tabular}{|c|c|c|}
\hline Momento & Conteúdo & Estratégia/ Material \\
\hline $\begin{array}{l}\text { Introdução } \\
5 \text { min }\end{array}$ & $\begin{array}{l}\text { Recepção dos participantes e } \\
\text { informações sobre as atividades da } \\
\text { sessão. }\end{array}$ & $\begin{array}{l}\text { Boas vindas aos participantes. } \\
\text { Recepção da sucata }\end{array}$ \\
\hline $\begin{array}{l}\text { Aquecimento } \\
15 \mathrm{~min}\end{array}$ & "Quem canta, os males espanta. Será?" & $\begin{array}{l}\text { Apresentação de músicas que } \\
\text { falam sobre violência contra a } \\
\text { mulher "Cabocla Tereza" e "Tiro } \\
\text { ao álvaro" } \\
\text { Material: violão, cantor e } \\
\text { projeção da letra da música }\end{array}$ \\
\hline $\begin{array}{c}\text { Desenvolviment } \\
\text { o } \\
75 \text { min }\end{array}$ & $\begin{array}{l}\text { 1. A violência contra a mulher como } \\
\text { problema social } \\
\text { 2. A violência contra a mulher e o } \\
\text { Programa de Saúde da família } \\
\text { Grupos } 1 \text { e 2: } \\
\text { OPSF que temos } \\
\text { Características das práticas à mulher } \\
\text { que vive em situação de violência no } \\
\text { PSF (Painel com sucata - } \\
\text { representação individual seguida de } \\
\text { grupal). Elaboração de uma lista das } \\
\text { principais características, diferenciando } \\
\text { positividades e problemas. } \\
\text { Grupos } 3 \text { e } 4 \\
\text { Vendo e vivendo o PSF que temos: } \\
\text { Dramatização de } 2 \text { casos reais } \\
\text { coletados anteriormente junto ao grupo. }\end{array}$ & $\begin{array}{l}\text { Material: roteiro, papel sulfite, } \\
\text { sucata; textos das histórias } \\
\text { digitadas, roupas e pequenos } \\
\text { outros acessórios para a } \\
\text { dramatização. } \\
\\
\text { Dinâmica da apresentação: } \\
\text { 1. Não participação dos atores } \\
\text { na apresentação das } \\
\text { características } \\
\text { 2. Enquanto as dramatizações } \\
\text { são feitas, os assistentes } \\
\text { deverão reconhecer as } \\
\text { características elencadas. }\end{array}$ \\
\hline $\begin{array}{l}\text { Síntese } \\
60 \mathrm{~min}\end{array}$ & $\begin{array}{l}\text { "A violência de gênero e as práticas em } \\
\text { saúde (no contexto do PSF e em outros } \\
\text { contextos)" }\end{array}$ & $\begin{array}{l}\text { Discussão grupal seguida de } \\
\text { exposição dialogada. } \\
\text { Material - computador, data- } \\
\text { show }\end{array}$ \\
\hline $\begin{array}{c}\text { Encerramento } \\
10 \mathrm{~min}\end{array}$ & Avaliação parcial da oficina & $\begin{array}{l}\text { Manifestações individuais sobre } \\
\text { o que achou da sessão. }\end{array}$ \\
\hline
\end{tabular}

Fonte: Fonseca, RMGS Oficina de Construção Coletiva "Mulher e violência: reconstruindo a assistência no âmbito do PSF" - Programação. Araraquara, nov. 2005. 
Os dados foram constituídos pelas falas em plenária dos relatores dos grupos acerca dos resultados dos trabalhos em cada uma das etapas das sessões. Tais falas foram gravadas e transcritas para posterior análise.

\subsubsection{Procedimentos éticos}

O presente estudo, que é parte integrante de um amplo projeto denominado "Práticas profissionais e violência contra as mulheres: um recorte de gênero e classe social", teve seu protocolo de pesquisa submetido à apreciação e aprovado pelo Comitê de Ética em Pesquisa da Escola de Enfermagem da Universidade de São Paulo (Anexo 1). Foram observados todos os aspectos éticos envolvidos na pesquisa com seres humanos.

Nas oficinas, precedia cada sessão a leitura e a assinatura doTermo de Consentimento Livre e Esclarecido (Anexo 2). Na ocasião, era assegurado aos participantes o sigilo das informações ali reportadas, que foram gravadas em fita cassete, como também o uso estrito do material para fins científicos.

\subsubsection{Tratamento e análise de dados}

Após sucessivas escutas, a gravação das oficinas foi transcrita, de modo a não se perderem aspectos importantes para a interpretação e análise, tais como: as palavras, os silêncios, as pausas, os choros, os risos, a pronúncia, as exclamações e interrogações etc., e conferida. Em seguida, os discursos foram corrigidos (quanto à ortografia e à gramática), 
preservando rigorosamente 0 conteúdo das falas e as expressões idiomáticas particulares e gírias. A apropriação do material não ocorreu de imediato, mas após muita leitura e organização dos discursos coletivos, optou-se pela análise de conteúdo por se entender que, dessa maneira, as falas estariam sendo observadas e consideradas a partir da ideologia do qual fazem parte os sujeitos.

Neste processo de análise de conteúdo, foram percorridas as seguintes etapas de apropriação do material e estabelecimento de um esboço inicial das categorias empíricas. Em seguida, foram priorizados os temas mais relevantes de acordo com o objeto de estudo, submetidos às categorias analíticas gênero e violência de gênero.

Para Minayo, a análise de conteúdo "enquanto técnica de tratamento de dados considerada cientificamente, é caudatária das metodologias quantitativas, buscando sua lógica na interpretação cifrada do material de caráter qualitativo" (Minayo, 2004: 200).

Do ponto de vista operacional e de acordo com a visão utilizada na presente pesquisa, a análise de conteúdo relaciona estruturas semânticas (significantes) com estruturas sociológicas (significados) dos enunciados. Articula o conteúdo dos textos, descrito e analisado, com os fatores que determinam suas características: variáveis psicossociais, contexto cultural, contexto e processo de produção da mensagem (Minayo, 2004). 


\section{RESULTADOS E DISCUSSÃO}

A diversidade existente no Brasil faz com que as mulheres brasileiras vivam realidades sociais bastante diferentes. Tanto suas opções e escolhas de vida no presente, quanto suas expectativas em relação ao futuro são influenciadas por visões de mundo muito distintas. Essas mulheres, entretanto, compartilham certos aspectos de uma identidade de gênero comum (Venturi, Recamán, 2004).

Considerando que mulheres e homens são constructos sociais, constituídos em gênero, raça/etnia, geração, classe social, esse enunciado poderia ser expresso na sua versão masculina, ou seja, a diversidade existente no Brasil faz com que os homens brasileiros vivam realidades sociais bastante diferentes. Tanto suas opções e escolhas de vida no presente, quanto suas expectativas em relação ao futuro são influenciadas por visões de mundo muito distintas. Esses homens, entretanto, compartilham alguns aspectos de uma identidade de gênero comum.

Mulheres e homens, estamos no mesmo barco social. Assim, é possível identificar traços comuns entre as mulheres e entre os homens. Além disso, dado que estão em relação, a cada perfil ou padrão social e historicamente construído de feminilidade, corresponde um perfil ou padrão socialmente construído de masculinidade. Isto, considerando-se as sobreposições das categorias, gênero, raça/etnia, geração, classe social, que por constituírem relações de poder, se revelam hierarquicamente de acordo com a maneira como a sociedade foi se constituindo na história da humanidade. Cada combinação possibilita conhecer a hierarquia de poder existente e entendê-la.

No tornar-se mulher ou homem, ambos vão se construindo num mundo que já está acontecendo. Assim é que pode-se dizer que gênero é constituinte da identidade dos sujeitos que, ao invés de únicas são plurais, 
múltiplas e que não sendo fixas ou permanentes se transformam, podem ser até contraditórias (Scott, 1995). Para Saffioti,

\begin{abstract}
"o sujeito múltiplo e não-único, por conseguinte, se inscreve no contexto histórico; seu registro não é individual, mas social. Se cada uma destas identidades é, em si própria, contraditória, na medida em que nem a ideologia de gênero, nem a de raça/etia e nem a das classes sociais apresenta coerência interna, evidentemente seu entrelaçamento potencializa estes antagonismos" (...) o sujeito, constituído em gênero, classe e raça/etnia, não apresenta homogeneidade. Dependendo das condições históricas vivenciadas, uma destas faces estará proeminente, enquanto as demais, ainda que vivas, colocam-se à sombra da primeira" (Saffioti, 2007:79).
\end{abstract}

Tais considerações esclarecem que as diferentes instituições (gênero, raça/etnia, classe, geração, nacionalidade etc.) e práticas ou espaços sociais (a justiça, a igreja, as práticas educativas ou de governo, a política etc.) são constituídas pelo gênero e também constituintes dos gêneros. "Estas práticas e instituições 'fabricam' os sujeitos" (Louro, 1997:25).

Nessa perspectiva, a subjetividade deriva da interação entre idéias e ações que identificam o "eu" na sua relação com os outros, formando assim o repertório de gênero. É sob essa ótica que se pretende discutir os resultados das oficinas de trabalho desenvolvidas junto às equipes do PSF de Araraquara. Para tanto serão utilizadas as categorias analíticas gênero e violência de gênero, como categorias históricas, ou seja, como processos em construção, do qual todos nós somos partícipes.

\title{
4.1. HOMEM E MULHER NO MESMO BARCO SOCIAL: METÁFORA GERANDO METÁFORA
}

A proposta da oficina foi falar sobre as identidades masculinas e femininas e relações de gênero. Para tanto, os profissionais foram 
orientados a usar objetos para representar o que pensavam sobre a metáfora, Homem e mulher no mesmo barco social.

A metáfora é uma figura de linguagem que consiste no emprego de uma palavra ou expressão em sentido diferente do próprio, para se construir relação de semelhança ou analogia. Estimulados pela dinâmica da sessão, os participantes também utilizaram metáforas para expressar suas idéias acerca de perfis de masculinidade e feminilidade que conhecem, aos quais estão acostumados.

Enquanto figura de linguagem, a metáfora serve para facilitar a comunicação, por descrever ou permitir compreender mais facilmente uma funcionalidade. Por exemplo, ao significarem a sensibilidade da mulher, os participantes utilizaram a flor, tanto quanto, para o casamento foi utilizada a metáfora da árvore.

(Discurso do grupo) .... mulher como uma flor, fez uma florzinha, a mulher sendo sensível e frágil como uma flor, uma flor aberta que está sempre pronta para receber, pra entender, receptiva pra amar e compreender as dificuldades.

(Discurso do grupo) Nesse casamento, aqui baseado na árvore, cada um tem suas diferenças (...). Têm flores que têm espinhos e não machucam, têm flores que machucam e infeccionam.

Ainda, referindo-se às relações de gênero os profissionais continuam a simbolizá-las, chamando atenção para o respeito que deve permear os relacionamentos afetivos.

(Discurso do grupo) Tem que saber respeitar porque chegamos à conclusão que temos que preservar a árvore desde o início, molhar, cortar, podar, para que nasça uma árvore bonita.

(Discurso do grupo) Ele tem que respeitar o lado feminino e pegar essa sensibilidade para ele, mas não esquecer que lá no fundo daquela relação, dentro daquela árvore que dá sombra, que dá frutos, que protege, ele tem que manter com a sensibilidade dele, respeitando o espaço da mulher, tem que proteger (...).

O barco como metáfora significa o espaço social, onde homens e mulheres caminham, navegam juntos. Se o barco é o espaço onde mulheres e homens vivem, quais são as condições dessa vida de relação entre 
homens e mulheres? Como concebem os profissionais do PSF de Araraquara as os papéis e identidades das mulheres e dos homens?

\subsubsection{Mulheres e homens: igualdade e diferença, papéis e identidades}

Os participantes da pesquisa reconhecem que mulheres e homens são diferentes, porém, ao tornar-se mulher ou homem, ambos vão moldando-se a um mundo que já está acontecendo e, com isso, as suas identidades vão se transformando.

(Discurso do grupo) Homem e mulher sendo diferentes, mas iguais na busca de identidade.

Para Louro, as identidades de gênero são construtos instáveis, continuamente se construindo e se transformando. Como femininos e masculinos os sujeitos vão se construindo, arranjando e desarranjando seus lugares sociais, suas disposições, suas formas de ser e estar no mundo mediante relações sociais, diferentes discursos, símbolos, representações e práticas.

\footnotetext{
"Essas construções e esses arranjos são sempre transitórios, transformando-se não apenas ao longo do tempo, historicamente, como também se transformando na articulação com as histórias pessoais, as identidades sexuais, étnicas, de raça, de classe..." (Louro, 1997:28).
}

A identidade é um conceito muito complexo, em decorrência da multiplicidade dos sujeitos. Uma vez que a subjetividade de cada um encontra-se nas contradições existentes entre raça/etnia, classe, esse 
entrelaçamento, feito um nó, ela seria responsável pela formação das múltiplas subjetividades (Saffioti, em 2006). ${ }^{1}$

A identidade de gênero se revela por meio de comportamentos associados com a feminilidade e a masculinidade. Para os profissionais do PSF, os homens sentem-se bem em proteger e, com isso, determinar quem detém e exerce o poder. No entanto, apesar desse poder, os homens mostram-se com características atribuídas ao feminino quando demonstram carência e dependência. Quanto às mulheres, embora estejam participando da esfera pública, respondem também pelo espaço privado, no que tange aos afazeres domésticos e na maternidade.

(Discurso do grupo) O homem sente-se bem em proteger, manter, mas também tem a sua carência, a sua dependência. A mulher busca também proteger, também ser mantenedora. Hoje é o papel da mulher também, porque ela é mãe, sensível e lutadora.

Para Louro, "papéis seriam, basicamente, padrões ou regras arbitrárias que uma sociedade estabelece para seus membros e que definem seus comportamentos, suas roupas, seus modos de se relacionar ou de se comportar..." (Louro, 1997:24).

Segundo Heller, papéis significam uma forma de praticar a imitação, pois "mesmo a vida social mais elementar seria inimaginável sem imitação" (Heller, 1992:87/88). No caso das mulheres, os papéis tradicionais de mãe e esposa são valorizados na definição de ser mulher, tanto como elementos positivos quanto como elementos negativos de sua condição - de mãe, pelo acúmulo de responsabilidades na criação dos filhos, e sobre ser esposa pela falta de autonomia decorrente do vínculo com o marido (Venturi, Recamán, 2004).

A construção de identidade feminina ocorre por duas vias, a primeira consiste na observação de papéis sociais desempenhados pela mãe, pois na observação cotidiana da atuação de uma mulher, a menina repara na mãe, aprendendo a ser mulher. A segunda, pela identificação pessoal: ao

\footnotetext{
${ }^{1}$ Safiotti, HIB., seminário "Serv. Social e Gênero: desafios contemporâneos para o exercício profissional", palestra: "Gênero e Patriarcado", em 21/10/2006, na FMU.
} 
brincar com bonecas, aprende a maternar posteriormente os filhos mediante a mímese. A mulher materna, ela materna, independentemente do grau de parentesco com a criança (Saffioti, 2004).

A ideologia dominante impõe aos homens papéis baseados na necessidade de ter êxito econômico, como provedor, mantenedor e protetor da família, ele sendo da esfera do trabalho é inserindo no espaço público. Quanto às mulheres, seu papel principal e reconhecido como marcante na identidade de gênero é a maternidade e, quase por conseqüência o cuidado das crianças e da casa, os chamados trabalhos domésticos.

Segundo Sorj (2004), em 96\% dos domicílios a mulher é a principal responsável pelas tarefas domésticas. Quando outra pessoa se responsabiliza pelas mesmas, ela também pertence ao sexo feminino. Comparativamente, enquanto elas gastam 48 semanais, em média, em tarefas domésticas, os seus parceiros gastam em média, 5,32 horas. A participação masculina com limpeza da casa é de 2,5 horas por semana, enquanto a feminina é de 28 horas. Com as crianças, eles gastam 3 horas, elas 18. Com os cuidados aos idosos, eles gastam meia hora, elas duas horas. Esses dados expressam que a participação masculina, além de limitada é seletiva (Sorj, 2004).

A carência e a dependência de alguns homens a que se referem os profissionais, exigindo cuidado, pode ser porque os homens passam toda a vida atendidos pelo sexo feminino, tendendo a desenvolver uma personalidade infantilizada, porque são cercados de devoção. Não aceitam críticas, não querem ser desobedecidos e acham que têm sempre razão (Castañeda, 2006).

A maternidade é vista como reforçadora dos papéis femininos, muito vinculada ao mundo natural, colocando a mulher em simbiose com a natureza e seus ciclos. Essa maneira idealizada de conceber o papel da mãe, como da mulher não leva em conta possíveis problemas enfrentados nas relações a esse respeito. 
(Discurso do grupo) Colocamos a natureza representada pelo verde, porque a mulher representa como se fosse os ciclos da natureza, ela dá a vida também, ela fica grávida.

Para Durand, o ciclo gravídico-puerperal constitui período de transição da identidade da mulher e do homem para a de mãe e de pai e requer do casal adaptação e uso de novos recursos e soluções.

\footnotetext{
"A crise que caracteriza este ciclo envolve a reativação dos conflitos do casal com suas figuras parentais, sendo o conjunto de sentimentos amorosos e hostis do homem e da mulher para com seus pais o ingrediente que orienta o curso psicológico da gestação na vida adulta" (Durand, 2006:184).
}

Para Rago,

\begin{abstract}
"Ser mulher, até aproximadamente o final dos anos 1960, significava identificar-se com a maternidade e a esfera privada do lar, sonhar com um 'bom partido' para um casamento indissolúvel e afeiçoar-se a atividades leves e delicadas, que exigissem pouco esforço físico e mental" (Rago 2004:31).
\end{abstract}

Esse papel restrito da mulher continha a idéia, na época, era que as mulheres deveriam desejar ser mães, resumindo sua essência ao útero, órgão esse inseparável das atividades fisiológicas, psíquicas e emocionais.

Ao contrário disso, a pesquisa da Fundação Perseu Abramo aponta que apenas $55 \%$ das entrevistadas dão valor à maternidade, sendo que a maior parte destas valoriza a maternidade em si mesma, isto é, o fato biológico, pois só $20 \%$ mencionaram o prazer propiciado pela maternagem (Saffioti, 2004).

Isto significa reconhecer que, para a maioria, a maternagem é um fardo. No percurso histórico sobre atitudes maternas, nasce a convicção de que o instinto materno é um mito (Badinter, 1985).

A maternidade aparece problematizada quando ocorre na adolescência. No discurso a seguir, os profissionais referem que muitas meninas perdem sua infância ou adolescência, devido à gravidez precoce. A gravidez precoce certamente interfere bastante na escolha e opções de projetos futuros de muitas jovens mulheres e também de jovens homens. 
(Discurso do grupo) A chupeta representa a infância... pensando que hoje as meninas engravidam muito cedo e assumem a responsabilidade de ser mãe, de ser dona-de-casa muito novas. Às vezes, elas podem sentir aquela sensação de querer voltar para a infância e não mais viver a vida que elas estão, ser mãe, dona-de-casa e responsável por uma família.

A gravidez na adolescência reflete as transformações na vida sociocultural nas últimas décadas que têm como uma de suas conseqüências o início da vida sexual de adolescentes cada vez mais cedo, caracterizando uma mudança do padrão de comportamento social e sexual. No Brasil, a proporção de nascidos vivos filhos de mães adolescentes, de 15 a 19 anos é de 20,0\%, sendo o maior índice no Estado de Tocantins, com $27,1 \%$ e o menor no Distrito Federal com 16,1\% (IBGE, 2003).

Um dos prejuízos para as mães é o limite da disponibilidade de recursos, o que acaba constituindo um empobrecimento nos projetos de vida e, portanto, repercutindo na qualidade de vida e oportunidades das mulheres adolescentes e seus filhos (Cabianca de Skaf, 2006).

Se nem sempre as mulheres, mesmo adultas, estão preparadas para serem mães, que dirá a adolescente-mãe, que é emocionalmente uma criança quando engravida? De modo geral, as grávidas adolescentes revelaram maior dificuldade para descrever suas percepções sobre o bebê do que as adultas. Além disso, suas expectativas quanto ao futuro do bebê estavam muito ligadas ao desejo de não repetição de sua própria história de gravidez precoce, dado ausente entre as adultas (Piccinini et al., 2003).

A ocorrência da gravidez durante a adolescência repercute negativamente na vida das meninas, por adiar suas atividades, sejam as escolares, sejam as outras próprias da faixa etária. Justamente por causa da idade, a gravidez ocorre quando ela está estudando. Trabalho realizado em Feira de Santana, na Bahia, em 2001, mostra que 85\% das adolescentes cursavam o Ensino Fundamental durante a gravidez e 14\% cursavam o Médio (Costa et al., 2005).

Outra pesquisa, realizada no interior paulista, mostrou dados diferentes: $31 \%$ das adolescentes estudavam quando engravidaram, a maioria cursando o Fundamental. Ao final da gravidez, apenas 14,3\% 
mantiveram as atividades escolares enquanto $60 \%$ as interromperam para cuidar do filho. As que voltaram a estudar contaram com o apoio da família (Almeida et al., 2003).

É comum que, após a gravidez, seja constatado o abandono escolar e a presença de novos filhos (Lourenço, 2003). Ocorre também mudança no estado civil (Costa et al., 2005) e da posição na hierarquia familiar (Fonseca, Araújo, 2004).

Nessa hora, ter suporte familiar faz diferença, pois as meninas que voltam a estudar precisam contar com isso. Porém, também para a família, esse acontecimento altera as relações: primeiramente, os familiares sofrem o choque pela notícia, depois passam a conviver com esse impacto e ficam inseguros diante de tanta mudança. Os sentimentos são ambíguos: da impotência, passa ao conformismo (Silva, Tonete, 2006).

Porém, tais sentimentos são transformados após o nascimento da criança; em geral, o que era apreensão agora é alegria, o que melhora o relacionamento da família. Evidencia-se também a frustração devido à interrupção ou mudança no projeto de vida familiar.

As mulheres adolescentes são, sem dúvida, as mais lesadas pela vinda da criança, mas os jovens parceiros não passam incólumes pela experiência. Há também prejuízo na continuidade ou no avanço da sua escolaridade e na remuneração, por serem obrigados a aceitar condições piores de trabalho (Costa et al., 2005; Barker, Nascimento, 2001).

Alguns meninos que se deparam com a possibilidade de tornarem-se pais propõem o aborto. No entanto, é difícil conhecer o tamanho do dano provocado ao co-responsável pela gravidez na adolescência, já que os órgãos oficiais de informação, tais como o Instituto Brasileiro de Geografia e Estatística (IBGE), e o Sistema Nacional de Registro de Nascidos Vivos (SINASC) não possuem dados que permitam conhecer as características sociodemográficas dos homens (Costa et al., 2005).

Para Trindade (2005), a vida dessas mães passa a ser marcada pelas condições de desigualdade em que vivem, tanto sociocultural como de gênero. Apesar de seus desejos manifestos, elas encontram poucas 
oportunidades objetivas de romperem com o contexto de vida em que estão inseridas. Para o futuro, está reservado para elas um cotidiano centralizado no cuidado dos filhos. Em geral, elas se tornam ou são obrigadas a se tornarem conscientes de que são as principais responsáveis por eles, voltando todos os seus projetos de vida para este cuidado. A imposição pela necessidade econômica, aliada à cobrança social é uma vida atrelada à responsabilidade da mulher com a maternidade (Trindade, 2005), no entanto, nota-se que os jovens contribuem com isso à medida que vêem a gestação de forma idealizada e a iniciação sexual sem prevenção, dificultando o planejamento real das obrigações e as dificuldades de ser mãe e pai.

Historicamente, a realidade aponta a gravidez na adolescência como um desperdício de oportunidades, pois os adolescentes pais interrompem supostas novas chances que lhes são oferecidas. Nisso também não há eqüidade no oferecimento de oportunidades sociais para jovens de diferentes classes. A gravidez precoce favorece antecipação da emancipação feminina, porém não sem prejuízo profissional e educacional para ela.

Para Lourenço, essa gravidez pressupõe o projeto de um novo papel feminino para a futura mãe, que pode ser concebido de duas maneiras: pela subordinação ou pelo empoderamento. A subordinação precoce traz situação de vulnerabilidade em relação ao sexo oposto. $O$ empoderamento possibilita ações direcionadas à auto-estima, à valorização, ao amor próprio e à segurança etc. Por isso, a gravidez na adolescência não deve ser encarada como problema singular da adolescente, mas sim como problema de toda a família e, em última instância, de saúde pública (Lourenço, 2003).

Em relação aos papéis femininos e masculinos apareceu também nas falas dos participantes o amor do pai pelo filho:

(Discurso do grupo) (...) significando um grande amor pelo filho, o filho é mais importante que tudo. Ele tem um carinho especial, ele vai buscar e levar o filho na creche, ele cuida assim do filho com muito carinho. 
A presença dos homens no espaço doméstico se destaca em atividades interativas, como cuidar de crianças e ajudar em trabalhos da escola. Para Safiotti, se o homem paternasse, teria a possibilidade de desenvolver sua anima (força feminina no homem, ligada à sensibilidade, afetividade, solidariedade etc.) e a mulher, seu animus (força masculina na mulher) e pais e filhos seriam mais equilibrados, mais sensíveis, mais saudáveis (Saffioti, 2004).

Ao apontarem essa questão, os participantes estão revelando o rompimento de alguns paradigmas por parte de mulheres e homens. Para Siqueira, "as novas formas de maternidade/paternidade desempenham um papel importante, uma vez que ainda são os pais os responsáveis pelas primeiras significações, modelos e representações que a criança apropriará" (Siqueira, 1999:198).

Isso significa que as mudanças nos papéis tradicionais já estão ocorrendo, pois segundo Heller a mímese humana contêm a idéia de atividade e "mesmo a imitação humana mais mecânica é assimilação ativa, porque o homem não pode alienar-se da sua natureza de um modo absoluto, nem sequer neste terreno" (Heller, 1992:88).

\subsubsection{Características do feminino e do masculino - emoção e razão}

Outra subcategoria identificada nos discursos foi a relativa às características do feminino e do masculino, baseadas na dualidade de sentimentos, atribuindo ao homem e a mulher, a razão e a emoção, respectivamente, revelando a concepção majoritariamente vigente na nossa sociedade:

(Discurso do grupo) Ele é mais racional e a mulher mais delicada, é bonita como uma flor. 
(Discurso do grupo) Temos o homem caracterizado - a maioria deles - pelo racional, simbolizado aqui pelo cérebro, a gravata, simbolizando a metade do laço porque a outra metade seria complementada pela mulher.

A cultura hegemônica vincula a mulher à emoção e o homem à razão. A visão através da diferença tem como base a essência. Assim, o que se tem é uma natureza feminina e outra masculina, como se homens não fossem emotivos e mulheres não fossem racionais (Castañeda, 2006).

Nesse caso,

"a razão não só se opõe à emoção, mas é associada ao mental, ao cultural, ao universal, ao público e ao masculino, enquanto a emoção é associada ao irracional, ao físico, ao natural, ao particular, ao privado e, obviamente, ao feminino" (Jaggar, 1997:157).

Embora a tendência da teoria do conhecimento ocidental (a epistemologia ocidental) tenha sido de privilegiar a razão ao invés da emoção, ela nem sempre excluiu completamente o emocional da esfera da razão. Não se pensava que se deveriam suprimir as emoções, mas que elas precisavam ser dirigidas pela razão, uma vez que, numa situação de perigo, considera-se não só irracional mas imprudente não sentir medo (Jaggar, 1997).

Ocorre que as emoções são positivas porque:

"os seres humanos se desenvolvem e amadurecem nas emoções
assim como em outras dimensões; eles aumentam o âmbito, a
variedade e a sutileza de suas respostas emocionais de acordo
com suas experiência de vida e suas reflexões sobre as mesmas"
(Jaggar, 1997:162).

Tanto para as mulheres, como para os homens, as emoções são consideradas importantes para o crescimento e nas relações de gênero em que ambos têm o ônus de não usar a razão ou não ser emotivo.

Ainda em relação à emoção, os participantes apontaram o amor como o lastro das relações afetivas homem-mulher, pontuando que ele pode aparecer de diferentes maneiras.

(Discurso do grupo) Chegamos à conclusão que na vida, na relação entre o homem e a mulher, o amor é o que segura. Pode ser aquele amor de amigo porque às vezes o amor acaba entre as 
pessoas, mas tem os filhos, então se tornam amigos e continua a relação.

Essa concepção teve sua origem na Idade Média com o chamado amor romântico que acabou influenciando a formação da família moderna e a criação de um lar. Além disso ele aparece na educação dos filhos, na valorização da maternidade e na relação entre pais e filhos.

Mas, para Giddens, "o amor romântico está sendo solapado pelo amor confluente". Os papéis tão definidos por mulheres e homens modificam-se e com isso alteram-se também as relações amorosas. $O$ amor confluente estaria assumindo o lugar do amor romântico e configurando uma nova família. $\mathrm{O}$ amor confluente é um amor ativo, contingente (casual, fortuito, incerto) e, por isso, entra em choque com as categorias "para sempre" e "único" da idéia do amor romântico Também os sonhos de amor romântico têm como acompanhamento a sujeição doméstica; o amor confluente, por sua vez, tem como princípio a igualdade na doação e no recebimento. O amor romântico era, de seu lado, um amor caracteristicamente feminino; às mulheres cabia amenizar a instabilidade do amado, que se mantinha frio e distante até que seu coração fosse conquistado (Giddens, 1993).

O casamento fundado na concepção moderna de amor singular, eterno e dirigido a um indivíduo único e insubstituível de certo período, no imaginário social romântico e burguês, pode ter ficado para trás. Nas circunstâncias históricas atuais, a noção de eternidade das relações e dos sentimentos foi abalada e isso se manifesta no fato de que casamentos e famílias passaram a desfazer-se e refazer-se continuamente (Vaistman, 2001). Para Feres-Carneiro, na sociedade contemporânea, "os indivíduos se divorciam não porque o casamento não é importante, mas porque sua importância é tão grande que os conjugues não aceitam que ele não corresponda às suas expectativas" (Feres-Carneiro, 1998: 385 ).

Segundo Giddens, em um relacionamento, a definição dos limites pessoais é fundamental. Limites claros são obviamente importantes para o amor confluente e para a manutenção da intimidade. No entanto, paradoxalmente, a abertura para o outro exige observação de limites 
pessoais, pois se trata de um fenômeno comunicativo. Exige também sensibilidade e tato, pois esse tipo de relação não é o mesmo que viver absolutamente sem pensamentos particulares (Giddens, 1993).

\subsubsection{Contra a negação do saber e do trabalho da mulher}

Para os participantes da pesquisa a proibição feita por alguns homens à mulher estudar é negativa. Admitem a existência de homens dominadores que determinam a maneira de viver de muitas mulheres. Para os profissionais esta maneira dos homens pensarem não permite 0 desenvolvimento das mulheres, pois desejam conformá-las à dedicação ao lar e aos filhos.

(Discurso do grupo) Outra atitude também negativa é que muitos homens ainda proíbem as mulheres de estudar, não querem.

(Discurso do grupo) Só que nós ainda vemos muitos homens que proíbem, que acham que não é importante para mulher estudar e aprender, se desenvolver.

Acontece que quanto menos as mulheres estudam, menores chances têm no mercado de trabalho. Como mostra a Fundação Carlos Chagas, a associação entre a escolaridade das mulheres e sua participação no mercado de trabalho é intensa. Assim como os homens, a atividade das mulheres aumenta entre os que têm mais de 8 anos de estudo (escolaridade obrigatória do I Grau), mas são as com 15 anos ou mais de escolaridade (nível superior) as mais ativas: $83 \%$ em 2002, ou mais de uma vez e meia a taxa de atividade feminina em geral (Fundação Carlos Chagas s/d).

Ao se referirem à importância de um diploma ou à falta de estímulo por parte dos homens, para que as mulheres estudem, os participantes da pesquisa vislumbram na educação uma possível saída para as mulheres e homens suplantarem as dificuldades existentes em suas relações 
assimétricas. No entanto, na fatia do mercado de trabalho em que se encontram os melhores empregos, a exigência por maiores níveis de escolaridade parece incidir mais sobre as mulheres do que sobre os homens: em 2002, eram 59\% os postos de trabalho ocupados por mulheres que exigiam nível de instrução médio e superior, mas a proporção de empregos masculinos com a mesma exigência para esses mesmos níveis era bastante inferior, com 36\% (Fundação Carlos Chagas, s/d).

Por outro lado, é no rendimento que o privilégio aos homens se evidencia mais: as mulheres, mesmo com maior escolaridade, ganham menos. Os dados deixam claro que homens e mulheres com igual escolaridade obtêm rendimentos diferentes. O fato é que as relações de gênero vão determinar valores diferentes para profissionais no mercado de trabalho conforme esse trabalhador seja homem ou mulher. E se a maiores patamares de escolaridade estão associados, de uma forma geral, maiores salários, isso é mais verdade para os homens do que para as mulheres. Para a Fundação Carlos Chagas, isso está evidenciado, pois:

- Mulheres ganham menos que homens independentemente do setor de atividade econômica em que trabalhem. No ramo da educação, saúde e serviços pessoais, espaço de trabalho tradicionalmente feminilizado, encontraremos uma maior proporção de homens (30\% versus $15 \%$ de mulheres) com rendimentos superiores a 5 salários mínimos;

- Quanto à posição na ocupação, mulheres sempre ganham menos que homens, seja como empregadas, autônomas, empregadoras ou trabalhadoras domésticas. No campo do trabalho doméstico, onde predominam as trabalhadoras, 94\% delas ganhavam em 2002 até 2 salários mínimos, enquanto $84 \%$ dos trabalhadores domésticos do sexo masculino tinham o mesmo vencimento;

- Da mesma forma, são menores os patamares de rendimento feminino, independentemente da jornada semanal de trabalho. Em 2002, entre aqueles que trabalhavam em período integral (de 40 a 44 horas semanais), ganhavam até 2 salários mínimos $57 \%$ das ocupadas e $51 \%$ dos 
ocupados; na outra ponta, com mais de 5 salários mínimos, 16\% dos homens e apenas $13 \%$ das mulheres;

- Quanto maior a escolaridade, maiores as chances de obter melhores rendimentos. Se isso é verdadeiro para trabalhadores de ambos os sexos, parece se aplicar mais a homens do que a mulheres. Com rendimentos dos mais altos níveis de escolarização, 15 anos e mais, ou com nível superior, tem-se $42 \%$ dos homens, mas apenas $18 \%$ das mulheres, têm rendimentos superiores a 10 salários mínimos.

\subsubsection{Mulheres, homens e trabalho doméstico}

De uma maneira geral, os profissionais do PSF criticaram negativamente os homens alheios, os que não contribuem com o trabalho doméstico.

\footnotetext{
(Discurso do grupo) Ela continua quantas jornadas forem possíveis, cuidando do marido, cuidando da casa, cuidando dos filhos. Ele fica lá no bem-bom esperando a cervejinha, cuidando do seu futebol.

(Discurso do grupo) O homem chega do serviço e não há continuidade do serviço dentro de casa. Então, é a mulher que faz tudo. Isto quando não tem que cuidar de tudo sozinha porque não tem homem em casa.
}

Há que se ter em conta que a família conjugal moderna estruturada através da divisão sexual do trabalho impediu o exercício da liberdade e igualdade de forma equivalente pelos dois sexos (Vaitsman, 2001).

Isto se torna ainda mais evidente quando se pensa nas mulheres sozinhas com os filhos sendo responsável pela reprodução tanto quanto pela produção social. Pesquisa do Instituto Brasileiro de Geografia e Estatística (IBGE, 2006), realizada em outubro de 2006 , revela que a maioria $(78,6 \%)$ das brasileiras chefes de família recebe menos de três salários mínimos $(R \$$ 1.050). As chefes de domicílio representam $29,6 \%$ das mulheres que 
trabalham nas seis principais regiões metropolitanas do país. Os resultados da pesquisa mostram que essas mulheres são mais velhas do que a média da população feminina ocupada, com menor nível de escolaridade, ocupam empregos mais precários, com nível de informalidade maior e enfrentam jornada de trabalho mais longa.

Incluem-se entre as chamadas mulheres chefes de família nos censos e estudos populacionais aquelas que estão nessa situação devido à dissolução do casamento, ao abandono, morte ou inexistência do marido. Para o Ministério da Saúde, "Hoje o status de pai/chefe de família deixou de ser natural e passou a ter que ser endossado, dentre outras formas, pela adequação do seu desempenho". Cita, inclusive, mudanças legais, como o pátrio poder, que passou a ser designado àquele que assume a responsabilidade parental, podendo ser exercido pelo pai ou mãe (Brasil, 2001:27).

Para o IBGE, o crescimento da participação das mulheres como chefes de família já configura uma tendência. De 2002 a 2006, esse percentual cresceu $20,9 \%$ e, em agosto de 2006, elas somaram 2,7 milhões de pessoas. Metade das mulheres que chefiam famílias mora sozinha com os filhos; $24,4 \%$ são casadas e $17,5 \%$ moram sozinhas. Uma em cada cinco chefes de família trabalha como empregada doméstica, sendo a participação dessa atividade de $21,9 \%$ contra $18,0 \%$ para o total de mulheres ocupadas. O grau de escolaridade das chefes de família é menor do que o das mulheres ocupadas em geral. Elas estudam em média 8,7 anos, contra 9,5 na população feminina ocupada e enfrentam uma jornada de trabalho mais longa: de 39,2 horas contra 38,7 horas para o total de mulheres que trabalham.

As chefes de família ganham $11,6 \%$ a mais do que a média das mulheres que trabalham, segundo a pesquisa. $O$ rendimento médio das principais responsáveis pelo sustento da família é de $R \$ 927,10$. A renda da população feminina ocupada, pelos dados de agosto, é de $R \$ 830,87$. O rendimento superior das chefes de família surpreende porque elas apresentam escolaridade menor, maior grau de informalidade e estão 
inseridas em segmentos de pior remuneração, como trabalho doméstico e trabalho por conta própria.

As mulheres que moram sozinhas contribuem para elevar a renda das chefes de família. Nesse grupo, 56,1\% das mulheres contam com 11 anos ou mais de estudo contra $38,8 \%$ para as que são solteiras e com filhos. Mas, mesmo com o efeito favorável das mulheres que moram sozinhas, as chefes de família ganham menos do que os homens. Segundo a pesquisa, a renda domiciliar em casas chefiadas por homens chega a $R \$ 2.116,28$. Nas casas chefiadas por mulheres, ela é de $R \$ 1.503,99$. A inserção no mercado de trabalho como conquista ou meta da maioria das mulheres é valorizada, sobretudo por possibilitar a construção de sua autonomia, ou ao menos por trazer independência econômica em relação aos homens.

Os participantes também reconhecem que as mulheres são as responsáveis pelo cuidado e, em geral, são responsáveis por mais de uma jornada de trabalho, o que Ihes acarreta muitas responsabilidades.

(Discurso do grupo) Essa sacola representa todos os cuidados que existem no ambiente familiar sob a responsabilidade da mulher, os cuidados com os filhos, com a família, a casa, comida, a roupa.

Mesmo quando desempenha uma função remunerada fora do lar, a mulher continua a ser responsabilizada pela tarefa de preparar as gerações mais jovens para a vida adulta. A socialização dos filhos, portanto, constitui tarefa tradicionalmente feminina (Saffioti, 1987).

Há um investimento social para tornar esse processo natural, delegar à mulher o espaço doméstico e conseqüentemente a sua capacidade de ser mãe. Assim, "é natural que a mulher se dedique aos afazeres domésticos, aí compreendida a socialização dos filhos, como é natural sua capacidade de conceber e dar à luz" (Saffioti, 1987:9).

"É próprio da espécie humana elaborar socialmente fenômenos naturais. Por esta razão é tão difícil, senão impossível, separar a natureza daquilo em que ela foi transformada pelos processos socioculturais. A natureza traz crescentemente a marca da intervenção humana, sobretudo nas sociedades de tecnologia altamente sofisticada. Há, portanto, ao longo da história, uma 
humanização da natureza, uma domesticação da natureza por parte do homem" (Saffioti, 1987:10).

Em 96\% dos domicílios em que residem mulheres, uma mulher é a principal responsável pela execução ou orientação dos afazeres. Em contrapartida, apenas $19 \%$ dos homens auxiliam nas tarefas. Essa desigualdade na divisão sexual do trabalho social torna evidente como o peso da dupla jornada de trabalho, com o acúmulo dos trabalhos remunerado e não-remunerado, tem recaído sobre as mulheres. A maioria das mulheres $(71 \%)$ concorda em dividir igualmente entre mulheres e homens o trabalho doméstico e $17 \%$ em parte: para $55 \%$ destas, mesmo que queiram, os homens não sabem realizá-lo, cabendo a eles, principalmente, o sustento da família para $65 \%$ de mulheres (Venturi,Recamán, 2004).

\subsubsection{Diferença, relação complementar, futuro e eqüidade}

De uma maneira geral, os profissionais representaram o homem e a mulher nas diferenças físicas. Expõem a diferença entre homens e mulheres baseados na força e na compleição física. Além disso, fazem referência a roupas e acessórios indicando um mundo masculino e outro feminino. $O$ atributo físico masculino é um argumento usado como representação da superioridade masculina, mas essa diferença e sua correspondente inferioridade é restritamente biológica.

(Discurso do grupo) Um homem representado por uma gravata, porque fisiologicamente ele é mais forte.

(Discurso do grupo) Nós discutimos e colocamos o que cada um pensa na verdade, que o homem e mulher têm diferenças de sexo, visualmente as vestimentas.

(Discurso do grupo) homem representado por uma gravata, porque fisiologicamente ele é mais forte. Não tem como comparar 
o corpo, às vezes, fisiologicamente de um homem com uma mulher, ele tem uma estrutura mais forte que a mulher.

É usual ouvir que as mulheres são diferentes dos homens e diferem porque eles são tomados como norma. Primordialmente, a diferença entre os gêneros referia-se a aspectos biológicos entre mulher e homem, tais como física, psíquicas, comportamentais, habilidades e talentos com teorias construídas para comprovar tais afirmativas. Essa diferença serviu para justificar lugares sociais, possibilidades e os destinos de cada gênero (Louro, 1997).

A diferença/desigualdade apresenta-se como uma dicotomia aparentemente verdadeira, pois igualdade - conceito político - supõe a diferença e não há sentido em reivindicar igualdade para sujeitos idênticos e sim equivalência, uma vez que os sujeitos não são idênticos. Para Scott,

\begin{abstract}
"precisamos rejeitar o caráter fixo e permanente da oposição binária, precisamos de uma historicização e de uma desconstrução autênticas dos termos da diferença sexual". Referese à desconstrução de Jacques Derrida, em que "esta crítica significa analisar no seu contexto a maneira como opera qualquer oposição binária, revertendo e deslocando a sua construção hierárquica em lugar de aceitá-la como real, como óbvia ou como estando na natureza das coisas" (Scott, 1995:9).
\end{abstract}

Para Saffioti (2004), distante de ser natural, a desigualdade se estabelece pela tradição à cultura, pelas estruturas de poder, pelos agentes envolvidos nas relações sociais.

\footnotetext{
"As diferenças pertencem ao reino na natureza, por mais transformada que esta tenha sido pelo ser humano, enquanto a igualdade nasceu do domínio do político, parece fora do horizonte de uma ideologia de gênero, que naturaliza atribuições sociais, baseando-se nas diferenças sexuais" (Saffioti, 2004:77).
}

O processo de construção social da inferioridade tem seu correlato na construção social da superioridade. As diferenças correspondem à constituição física do homem como forte, viril e também a seu temperamento durão, em oposição a mulher cuja compleição física é tida como delicada, e seu temperamento é atribuído à docilidade. Mulheres vão sendo educadas para serem frágeis, submissas, boas mães, boas filhas e também boas 
esposas; em contrapartida, para os homens a educação tem como base a força, a virilidade, que se traduz em masculinidade.

Para Louro, é imperativo contrapor-se a essa argumentação, não são as características sexuais, mas as formas como essas são representadas ou valorizadas, aquilo que se diz ou se pensa sobre elas, é que vai constituir o que é masculino e o que é feminino numa dada sociedade, num dado momento histórico. Para a compreensão do lugar e as relações de homens e mulheres, importa observar não seu sexo, mas tudo o que socialmente se construiu sobre os sexos (Louro, 1997).

Numa tentativa de desconstruir a desigualdade, nos seus discursos, os trabalhadores de saúde do PSF referem a relação complementar como ideal, pois, para eles, mulheres e homens são seres incompletos. Essa idéia de acrescentar o que falta para torná-lo completo ou perfeito é completamente equivocada, pois tanto aos homens, quanto às mulheres, não Ihes falta nada que exija complemento.

(Discurso do grupo) O homem e a mulher um completando o outro, então esse seria o ideal (...)

(Discurso do grupo) quando a vida faz com que eles em algum momento se encontrem devem perceber que um completa o outro (...)

Essa noção de complementaridade é uma abordagem pré-moderna da conduta humana, pois implica diferenças claramente definidas. Atribuí-las a características fixas de homens e de mulheres, aprisiona ambos em polaridades, ignorando os conhecimentos gerados (Castañeda, 2006).

$\mathrm{Na}$ frase abaixo, os profissionais acrescentam à complementaridade, a simbologia, como se, o coração e o amor fossem inerentes do feminino e por sua vez complementares do masculino.

(Discurso do grupo) A mulher simbolizando o coração, a intenção, o amor, então um completando o outro.

Os símbolos culturalmente disponíveis são um dos quatro elementos da diferença percebida pelos sexos. Eles evocam representações múltiplas e freqüentemente contraditórias. A partir da categoria gênero pode-se 
perceber a organização concreta e simbólica da vida social e as conexões de poder nas relações entre os sexos. Estas diferenças se fundam em símbolos culturalmente disponíveis que evocam representações simbólicas e mitos. São os conceitos normativos que põem em evidência as interpretações do sentido dos símbolos, que se esforçam para limitar e conter suas possibilidades metafóricas, eles são expressos em doutrinas religiosas, educativas, políticas ou jurídicas e que opõem de maneira binária e inequívoca as concepções de masculino e feminino (Scott, 1995).

Ainda pontuando que as diferenças se situam no campo biológico, os profissionais referem que durante a fase da gestação os homens não entendem as diferenças de gênero, reforçando a ligação da mulher com a natureza, especialmente na gestação.

(Discurso do grupo) Temos uma gestante, uma mulher grávida e seu marido. Esse homem muitas vezes não consegue entender as diferenças que existem entre o gênero masculino e o feminino e todo aquele momento, que vivencia a mulher na gestação.

Sabe-se que a gravidez é um período de muitas transformações na mulher, transformações essas que incluem os sentimentos. Para alguns homens, a maternidade é sinônimo de muitas perdas, o que, ao final se resume em aumento da responsabilidade.

\subsubsection{Superando as diferenças}

Apesar de majoritariamente os profissionais pontuarem que as diferenças se situam mais no campo do biológico, contraditoriamente, apontam também que uma das vias de superação das diferenças podem ser feitas através dos filhos, desde que preservada sua inocência.

(Discurso do grupo) Esse homem e essa mulher criam um relacionamento onde nascem os filhos, e nós chegamos à conclusão que esses filhos devem ser simplesmente preservados, 
na inocência deles, tem-se que tentar colocá-los numa linha de vida para poder mudar as diferenças, que há hoje em dia.

Através da educação formal e dos meios de comunicação, são ensinadas às pessoas novas formas de agir e pensar. $E$ as crianças, obviamente, não se excluem desse processo. As transformações nesse sentido têm avançado e Siqueira cita uma pesquisa realizada nos Estados Unidos, em que crianças cuidadas por mais tempo pelo pai demonstram maior flexibilização no que diz respeito às relações e papéis de gênero, em relação às crianças criadas em famílias tradicionais (Siqueira, 1999).

Os profissionais ainda expressam que mudanças positivas nas relações de gênero podem acontecer via formação educacional, valorizando o diploma para os homens e para as mulheres como um meio para que sejam superadas as questões de gênero.

(Discurso do grupo) Então, temos aqui um diploma, um diploma escolar para o homem e um diploma escolar para a mulher também, pois nós somos seres humanos, temos o direito de evoluir, crescer e ter conhecimento, tanto homem como mulher.

A igualdade pressupõe a eqüidade de gênero.

\begin{abstract}
"Adotar a eqüidade de gênero como um conceito ético associado aos princípios de justiça social e de direitos humanos não implica em desmerecer ou desvestir de direitos os homens para privilegiar as mulheres (...). Trata-se de re-olhar, com esmero e cuidado, a situação de milhares de mulheres que sofrem iniqüidades no cotidiano, indignar-se com isso e mover-se para as transformações, sem confundir o direito à assistência digna e respeitável por serem, antes de tudo, cidadãs, com o imperativo de tê-las hígidas e produtivas, por serem geradoras e mantenedoras da força de trabalho presente e futura, portanto, de quem a sociedade depende para a geração de riqueza social" (Fonseca, 2002:13).
\end{abstract}

Nesse sentido, a transformação da situação social das mulheres passa pela liberdade a ser conquistada. A esse respeito, comparando as mulheres a árvores ou a pássaros, Rubem Alves afirma:

"Diz-se que antigamente as mulheres se pareciam com árvores. As árvores não saem do lugar. Crescem onde plantamos. Indefesas. Não reagem, não fogem, não gemem - nem mesmo quando são cortadas a machado. Pois assim eram as mulheres: nasciam e pelo resto de suas vidas teriam de obedecer aos homens. Primeiro, tinham de obedecer as ordens do pai. Depois, 
tinham de obedecer as ordens do marido. (...) Na verdade, nem antes de casar elas estavam livres. Estavam à mercê da vontade dos pais. Era o pai que decidia se ela devia se casar, quando e com quem. E nem tinham a liberdade de se decidir por uma profissão. Lugar de mulher era na casa, no fogão, na máquina de costura. As mulheres não eram donas do seu corpo, não mandavam no seu destino. Árvores à mercê da vontade do jardineiro, sem poder fugir... Como gostariam de ser pássaros, e voar para longe, longe... Não podendo ser pássaros, as árvores dão flores. Flores são os pássaros das árvores. Flores são vôos que não conseguiram voar e se cristalizaram em beleza e perfume. Quem dá uma flor a alguém está lhe dando um desejo de voar. Outro jeito que as mulheres-árvores tinham de florir eram os filhos. Se elas não podiam voar de verdade, voavam imaginando os filhos voando. Viviam uma vida simples, modesta, sempre plantadas no chão - e eram sempre uma sombra e um colo onde os filhos tristes encontravam conforto. Especialmente nas coisas gostosas que só as mães sabiam fazer na cozinha. Fazer o prato predileto do filho: era 0 jeito que elas tinham de dizer às noras: "Você nunca tomará o meu lugar!" Claro, havia umas mulheres revoltadas por não poder voar. Viravam cactus, só espinho. E os filhos sofriam. Minha avó era assim - que Deus a tenha. Mas não minha mãe, que aprendeu ternura com uma velha escrava chamada láiá. Por vezes as mães verdadeiras não são as mães de barriga - são as mães de coração. As mulheres, hoje, se cansaram de viver para fazer vontade de pai e de marido. Estão se transformando em pássaros: querem voar - determinar o seu destino, ser donas de suas vidas. Liberdade: esse é um direito de todo ser humano" (Alves, s/d).

\subsection{VIOLÊNCIA DE GÊNERO: O QUE PENSAM OS TRABALHADORES DO PROGRAMA DE SAÚDE DA FAMÍLIA}

Todo discurso é ideologicamente situado e toda interpretação é construída, aprendida e apreendida historicamente. Os discursos a seguir relatados, sobre a violência de gênero, serão vistos sob a ótica da construção social do masculino e feminino, entendendo que a supremacia masculina nas relações de gênero tem permitido que o homem lance mão da violência para manter sua dominação, exercendo-a em favor de seu domínio e interesse, quando esses se encontram ameaçados. Os discursos dos profissionais de saúde a respeito de violência de gênero, referiu-se mais àquelas que ocorrem no âmbito doméstico. 


\subsubsection{Em mulher não se bate nem com uma flor}

Os profissionais da saúde utilizam um velho provérbio para expressarem que mulheres não devem ser alvo de ataques, nem de flores, ou seja, para eles é inaceitável que as mulheres sejam agredidas.

(Discurso do grupo) Lembrando daquele ditado: na mulher não se bate nem com uma flor.

No entanto, a despeito de tais discursos as pesquisas revelam que as agressões às mulheres são bastante comuns. Um estudo realizado com 100 homens denunciados nas delegacias especializadas de Pernambuco, Estado onde é muito comum a violência de gênero, entre setembro e outubro de 2005, revela que há uma prática recorrente de violência de gênero. Dos homens denunciados, apenas 36\% concordavam com o ditado: "em mulher não se bate nem com uma flor", ou seja, mais da metade deles acredita que, dependendo das circunstâncias, têm o direito de bater na mulher.

O Departamento Policial da Mulher da Polícia Civil, responsável pela pesquisa, traçou um perfil indicando que o agressor pernambucano padrão tem entre 25 e 40 anos, é casado formalmente com a companheira, tem de um a três filhos, cursou somente o ensino fundamental, está empregado e ganha pouco mais de um salário mínimo. Na maioria das vezes, a acusação que pesa sobre ele é a de ter ameaçado de morte ou espancado a vítima, no entanto, a maioria (72\%) não reconheceu a agressão cometida. Diz a delegada Cláudia Molina, especializada em crimes contra mulheres, que "o homem chega à delegacia achando que a mulher o denunciou para confrontá-lo, para humilhá-lo. Eles não acham que o que fizeram é crime e que a mulher está em busca de ajuda" (Pernambuco.com, 2004).

Apesar da agressão configurar crime, muitas vezes a mulher que busca ajuda policial o faz visando à interrupção da violência, mas não do relacionamento, conforme demonstrou estudo realizado em Florianópolis. A 
delegacia é vista por mulheres como um lugar de mediação. A retirada da denuncia é comum, já que o pedido de auxílio é também permeado, muitas vezes, pela expectativa de que a intervenção policial poderá, ao coibir a violência, restaurar a estabilidade do relacionamento (Vieira, Palavezzini, 2006).

Izumino (2004) analisou o conflito de gênero e sua solução no sistema judiciário, na fase da denúncia policial. O relato das mulheres é dramático e mostra o desejo de punir o agressor, embora na fase judicial não queiram sua punição. Como as mulheres não têm poder para interromper o processo de violência, utilizam a justiça como instância mediadora para a renegociação do pacto conjugal.

Sabe-se que a construção social de gênero é a grande responsável pela naturalização da violência, tanto por parte dos homens como por parte das mulheres. As falas dos profissionais de saúde referem que a barreira cultural é difícil de ser quebrada, pois os valores estão arraigados. A respeito disso, não mencionam que essa cultura é construída e constrói homens e mulheres socialmente e é nela que as ações e as relações se efetivam. Deriva disso também, o não reconhecimento da violência por parte das mulheres, pois sejam em casamentos formais ou em uniões estáveis, elas acreditam que os ditames do companheiro devem ser seguidos, em respeito à posição de poder do homem na relação.

(Discurso do grupo) Então essa é uma barreira difícil de ser quebrada, a barreira cultural mesmo, os valores pessoais que a pessoa tem, porque isso vem lá de longe.

(Discurso do grupo) (...) nós colocamos a barreira cultural, às vezes, é próprio da mulher achar que isso não é violência, foi criada assim, foi tratada daquela maneira, que é normal, que é certo, então ela não encara, às vezes, como violência (...)

A naturalização da violência nas relações como processo cultural corresponde a uma etapa evolutiva na transmissão de tradições e valores. Nas relações, essas agressões acabam por se tornarem rotineiras e acentuam-se com o tempo, devido à sua freqüência. As mulheres aceitamna como destino. De tão normal passa a ser banalizada, vista como parte inexorável das relações do casal, constituído na formalidade ou na 
informalidade. Mesmo que aconteçam entre parceiros do mesmo sexo, há sempre um caráter de gênero, uma vez que faz parte das construções sociais de homens e mulheres, inseridas em relações assimétricas. Essa desigualdade confere a um dos pares, maior poder e autoridade, atribuições constituídas pela cultura (Schraiber et al., 2005).

Por acreditar em normas e costumes predominantes, a mulher é constrangida a manter relações sexuais como parte de suas obrigações como esposa. Apenas 55\% das mulheres que relataram agressão física e/ou sexual perceberam o vivido como violência. Isso ocorre porque as mulheres não nomeiam a situação doméstica como violência (Schraiber et al., 2002).

O tradicional controle masculino baseado no papel de provedor está em xeque e a resistência à transformação, tanto por parte do parceiro como da parceira, radicaliza conflitos e colabora para a ocorrência da violência, inclusive sexual, entre o casal (Dantas-Berger, 2003).

Mulheres aceitam o sexo forçado no casamento, na crença de que é dever da esposa satisfazer o companheiro. Não rompem com isso, por vergonha e medo de ter sua intimidade devassada, além do medo de não ser compreendida (Brasil, 2001:19).

A respeito da mulher provedora do lar, os profissionais de saúde destacam que a cultura também se interpõe na dissolução do casamento, mesmo que na sua manutenção esteja presente a violência. Porém, os profissionais não mencionam que essa mesma cultura é que impede a auto percepção da mulher, que suporta agressões em nome da família e de convenções impostas socialmente. Na frase abaixo, os profissionais referem que a mulher agredida sequer se reconhece como mantenedora na relação, suportando agressões em nome da família e de convenções impostas culturalmente.

(Discurso do grupo) (...) é a barreira cultural, porque foi-nos contado um caso assim: a mulher era a provedora, ela que bancava tudo, ela era independente, mas culturalmente ela sentia que, os filhos, a família não se pode dissolver, mesmo com um esposo alcoólatra. Ele batia nela, na cabeça dela, ela acreditava piamente que a partir do momento que casou, deveria ficar com aquele homem, para criar a família. 
Porém, ao mesmo tempo em que isto perdura, o que se verifica é também uma transição nas relações de gênero. Para Negreiros e FéresCarneiro (2004), o que se presencia hoje é a transformação do masculino e do feminino na divisão de papéis, não perdurando no modelo atual de família exclusivamente o homem como provedor e a mulher como responsável pela casa e pelo cuidado dos filhos.

No campo familiar, as mulheres vêm aumentando a sua participação como pessoas de referência no domicílio. Partindo desta perspectiva, Schraiber et al. (2005) destacam aspectos culturais importantes de mudança de valores, como:

1) o processo de individualização e autonomia de mulheres: a individualização rompe com a tradição da autoridade exclusiva masculina e provoca instabilidades nas relações interpessoais, originando tensão.

2) a autonomia da mulher sobre a sexualidade e a reprodução: essa liberdade de escolha é particularmente tensionadora das relações, porque contesta o homem como regulador da sexualidade feminina.

3) o aumento das mulheres no mercado de trabalho

4) aumento do nível de escolaridade das mulheres (Schraiber et al., 2005).

A crescente autonomia das mulheres, com suas ações contraculturais, aliada à mudança do padrão de autoridade paterna, possivelmente provocam acirramentos nas relações de gênero. Na frase a seguir, os profissionais afirmam que a guerra começa sempre em casa, referindo-se à violência de gênero que ocorre no espaço familiar em decorrência da falta de respeito mútuo. No entanto, não se dão conta de que esse desrespeito pode residir na iminência da perda do status quo na relação por parte do homem, assim como na progressiva ocupação desse espaço pela mulher, desencadeando resistências. 
(Discurso do grupo) Durante a trajetória desse barco, o homem e a mulher precisam primordialmente de respeito mútuo para dar continuidade ao ciclo da vida; esses conflitos só levam a violências tantas: moral, física, psicológica etc., não permitindo ao outro crescer e evoluir como ser humano. A guerra começa sempre em casa.

\subsubsection{Mulher frágil, homem forte: relação desigual gera violência}

Os profissionais referem que a falta de auto-estima das mulheres é que permite a violência pelo homem, vinculando a falta de auto-estima à fragilidade da mulher.

(Discurso do grupo) (...) um pouquinho da falta de auto-estima que muitas vezes a mulher tem, por isso ela se permite ser violentada, tanto física, quanto psicologicamente.

(Discurso do grupo) muitas vezes mostra que a mulher é frágil, é o que ela passa, só que a mulher deve ser tratada como ser humano, se achar bonita e mostrar para as pessoas que ela é bonita e não que é uma coisa frágil que tem ser deixada de lado, guardada para não quebrar - e muitas vezes o homem acaba quebrando.

Para o Ministério da Saúde,

"pensar que a mulher é frágil e dependente do homem ou que o homem é o chefe do grupo familiar pode levar as pessoas a concluírem que é natural que os homens tenham mais poderes que as mulheres e os meninos mais poderes que as meninas" (Brasil, 2001:15).

O tempo de exposição às agressões, seguramente deteriora na mulher o seu amor-próprio, o "estimar-se a si".

Para Fonseca (2002), auto-estima é "o valor do sujeito atribuído a si mesmo, adquirido através da convivência com seus pares e com demais sujeitos no espaço das relações sociais" (Fonseca, 2002:26).

Para que a auto-estima se construa ou fortaleça é preciso haver reforço positivo, funcionando como incentivo, o contrário do que ocorre em relações violentas onde há reforço na depreciação e na desqualificação da 
mulher. Sendo a beleza exterior, ela pode ser produzida como disfarce para esconder as agressões que experienciam, esteticamente. Por isso, dizem os profissionais que ela não pode perder a vaidade.

(Discurso do grupo) (...) porque a mulher, mesmo passando por todos esses problemas, ela não pode perder a vaidade. Ela não pode deixar de se cuidar, de ficar bonita.

Porém, com isso, sugerem às mulheres que escondam a violência e que não reajam. Para os profissionais, são as perdas sofridas pelas mulheres, de auto-estima, da vaidade, além do medo e da vergonha da sociedade que as fazem se sentir incapazes.

(Discurso do grupo) (...) nós colocamos a baixa auto-estima, a perda da vaidade, a insegurança, o medo, e a vergonha da sociedade, ela começa se sentir incapaz.

A percepção que de as mulheres se sentem incapazes, no entanto, as coloca numa posição de vítimas, incapacitadas para reagir. Ocorre que, ao invés disso, elas são cúmplices da situação, estabelecendo uma relação de dependência em que, apesar da infelicidade, ambos se completam. Em relacionamentos violentos, mulheres e homens se mostram dependentes um do outro, sendo que essa dependência pode ser de várias ordens: afetiva, psicológica, intelectual, financeira, etc. Assim, quando as mulheres pensam que é sina manterem-se em relações violentas, no papel de vítima, elas mesmas se vitimizam. De outra parte, quando os próprios profissionais as vêem como se estivessem cumprindo seu destino, eles mesmos as vitimizam.

Estudiosos explicam que pelo fato das mulheres viverem anos em situações de violência, afetando severamente sua auto-estima e sua confiança, diminuindo suas capacidades de reagir, de buscar emprego, de participar plenamente na sociedade; elas buscam menos apoio porque acham que não serão escutadas, nem acreditarão nas suas demandas; sentem que não têm opções e por último, frente às poucas possibilidades, torna-se mais difícil qualquer iniciativa pessoal para enfrentar a violência. $O$ fato é que a violência de gênero é um problema que tende a diversificar-se e 
a piorar através do tempo, tornando-se mais intensa e freqüente, se não houver uma intervenção apropriada para tentar deter essa escalada de fatos (Heise et al., 1994).

(Discurso do grupo) (...) vive com o agressor devido a dependências econômicas, psicológicas e até mesmo achar que é a sina dela apanhar todos os dias e sofrer essas agressões.

Originalmente o termo co-dependência foi usado para descrever a relação disfuncional entre a esposa e seu marido alcoólatra. Para Humberg (2004), além dos problemas emocionais e interpessoais, muitos codependentes também sofrem de outros problemas compulsivos, como comer, gastar e jogar compulsivamente; e muitos dos alcoólicos em recuperação começaram a apresentar comportamentos compulsivos como seus parceiros co-dependentes. Ela constata que não apenas a esposa, mas outros familiares podem desenvolver a "dependência do vínculo", termo proposto pela autora para revelar que a dependência não é um atributo de uma das pessoas envolvidas, mas de ambas (Humberg, 2004).

Assim, é possível empregar o termo dependência do vínculo para além de usuários químicos, observar tal relação é importante para elucidar determinados aspectos do fenômeno, com também refletir a respeito das relações violentas onde um ciclo se estabelece.

Alguns estudos captaram os sentimentos de vítimas nas mulheres. Para Yoshihama (2002), o abandono traduz a realidade de mulheres agredidas. As mulheres que sofreram lesão corporal dolosa apresentaram sentimentos de raiva, tristeza, indignação, insegurança e medo, o mais freqüente (Moura; Oliveira, 2000). Sobre si mesmas, seus casamentos e de seus companheiros, os sentimentos são essencialmente negativos, desesperançosos e repletos de ressentimentos. O autocuidado é negligenciado e elas apresentam sintomas distímicos (Cabral, Brancalhone, 2000).

Quando vitimizadas, mulheres agredidas por seus companheiros sentem-se impotentes diante da vida, das violências e incapazes de mudar seu destino. Para Ramão et al. (2005), a queixa e a expectativa colocada no 
assistencialismo como forma de resolução dos problemas são decorrência de processos que paralisam, homogeneízam e congelam a sua capacidade de produzir desejo. Em Oficinas de promoção à saúde e gênero, as autoras observaram num grupo de mulheres atitudes recorrentes que ativam as marcas de submissão, de dependência, de dor e de angústia. $O$ estudo também propiciou o fortalecimento da rede de apoio/atendimento, bem como a visibilidade das políticas setoriais.

Para Santos e Izumino, "é necessário relativizar o modelo de dominação masculina e vitimização feminina para que se investigue o contexto no qual ocorre a violência" (Santos, Izumino, s/d). Para as autoras, a mulher colabora com isso, na medida em que resiste e perpetua papéis sociais que a colocam como vítima. Além disso, o discurso vitimista limita a análise da dinâmica da violência.

Em oposição à fragilidade das mulheres, os homens são fortes. Essa dicotomia é utilizada pelos profissionais de saúde para caracterizar mulheres e homens. Enquanto o homem é visto como uma rocha, o agressor é um facínora - indivíduo que executa um crime com crueldade ou perversidade acentuada (Houaiss, 2004:330).

(Discurso do grupo) Por mais que o homem seja aquela rocha (...).

(Discurso do grupo) (...) que ela possa entender que ela pode viver mesmo que sozinha, mas que não seja obrigada a viver com um facínora, que a violenta, que a maltrata.

Interessante foi verificar que os profissionais fazem menção à ligação entre o homem e um chapéu militar, referindo-se à imposição de uma disciplina rígida ou do autoritarismo do homem dominador sobre a mulher. Há consenso que, em menor ou maior grau, a maioria dos homens carrega consigo traços de dominação, podendo expressá-los em violência física, atitudes de controle, na exigência de obediência, em comentários desqualificadores, como também na proibição. A inserção da autoridade masculina no relacionamento, dá-se gradualmente, aderindo-se às relações e suas manifestações acontecem no cotidiano, de várias maneiras, inclusive sutilmente, o que dificulta sua percepção. 
O homem dominador se mostra exacerbado em comportamentos atribuídos à sua masculinidade - ele tem comportamentos que tendem a negar à mulher os direitos concedidos a si. Mas, a mulher não está imune a tais comportamentos e compartilha do domínio do homem, na medida em que ignora as estruturas de poder que regulam as relações entre os gêneros, as reproduz ou contribui para que os homens continuem reproduzindo-as.

(Discurso do grupo) Colocamos, na escultura, um homem representado também por um chapéu militar, um homem machista, aquele homem mandão.

(Discurso do grupo) Falando um pouquinho do homem - porque o tema é homens e mulheres - sobre o machismo no homem, a responsabilidade do homem: muitas vezes é o homem que trabalha para manter a família toda, a superioridade $e \quad 0$ autoritarismo também.

Para Castañeda, cada cultura constrói discursos específicos de masculinidade transmitindo a ideologia machista pela linguagem, mídia, música, literatura popular e leis. Do ponto de vista histórico, o termo machismo está associado ao sistema social e familiar patriarcal. Em linhas gerais, as teorias sobre 0 machismo podem ser divididas em duas categorias: há as que, seguindo preceitos biológicos, argumentam que homens são machistas por razões inatas e basicamente invariáveis. Esse enfoque essencialista atribui explicações originárias da biologia, da etologia, da teoria da evolução e da psicanálise, como se muitas condutas e atitudes emanassem da anatomia, do biológico. Outras explicações para o machismo derivam de estudos de gênero, da antropologia e da etnografia, da sociologia e da história. Fundamentam-se em aspectos sociais, econômicos e culturais para afirmar que o machismo não nasce com o indivíduo, é aprendido (Casteñada, 2006).

$\mathrm{Na}$ fala a seguir, os profissionais criticam as atitudes do homem dominador, pois ele não compartilha a gestação dos filhos com as futuras mães. Ao contrário, é um homem distante da paternidade, não dispensando à mulher companhia, amor e carinho. 
(Discurso do grupo) (...) às vezes, a mulher acaba ficando grávida sozinha mesmo, sem a companhia, sem o amor, o carinho do esposo que ela precisaria tanto no momento. Uma atitude negativa, machista que precisa ser modificada e que nós ainda vemos.

Para DeSouza et al. (2000) o machismo, especialmente em termos do mundo hispânico ocidental é descrito em termos de indiferença à família, de distanciamento dos filhos, resistência a adversidades, assédio sexual, capacidade de beber muito, agressividade contra outros homens e dominação em relação às mulheres.

Sobre o domínio do homem e a percepção das mulheres sobre este, pesquisa da Fundação Perseu Abramo obteve os seguintes resultados: a existência do machismo é quase absoluta para (89\%) na sociedade brasileira; para $73 \%$ das mulheres há muito machismo e para $17 \%$ um pouco. Apenas $2 \%$ afirmam que na sociedade brasileira ele não existe, porém $7 \%$ não sabem o que é o machismo. Comparada às outras regiões, no nordeste as mulheres têm uma menor percepção da sua existência. Nas capitais, as mulheres percebem-no mais do que no interior, as urbanas mais do que as do campo (Soares, 2004).

Muitos homens apresentam o perfil próprio do machismo, sempre descrito nos mesmos tipos de indivíduos: exigente, controlador, impaciente e mal-humorado (Castañeda, 2006).

A pesquisa da Fundação Perseu Abramo também mediu a percepção das mulheres sobre feminismo, $12 \%$ das mulheres consideraram-se totalmente feministas, $16 \%$ parcialmente, enquanto $71 \%$ não seriam. Dessas, $43 \%$ não se consideraram e $18 \%$ disseram não saber o que é ou não souberam classificar em $4 \%$, sendo $7 \%$ confundiram feminismo com feminina. Não houve muita distinção entre mulheres que vivem nas capitais, estados e cidades do interior, variando um pouco a depender do porte do município. Ao feminismo, foram associadas: a superioridade da mulher em relação ao homem, com $12 \%$. Para $7 \%$ das entrevistadas, as feministas são autoritárias, mandonas ou briguentas.

Para Soares, 
"pelas respostas, o feminino está principalmente associado à luta pela igualdade de direitos entre homens e mulheres, seja em sentido amplo (22\%), seja especificamente no mercado de trabalho (8\%). Outros $15 \%$ o identificaram com mulheres livres, social ou economicamente independentes, com autonomia para fazer o que querem, sem depender da aprovação do parceiro/marido ou de terceiros" (Soares, 2004:165).

Com relação à imposição dos desejos do homem sobre a mulher, as falas dos profissionais relatam conhecimento das situações, das mais variadas formas:

(Discurso do grupo) (...) o homem que trabalha, com uma bengala, pois tem que ser o provedor e dessa forma a mulher não pode sair de casa pra trabalhar, ela tem que ficar dentro de casa, quietinha, bonitinha e não pode conquistar sua independência.

(Discurso do grupo) Ele é o homem da casa, ele manda em tudo e a mulher não apita nada.

(Discurso do grupo) Ela só tem que obedecer e ela é uma mulher delicada, frágil e não tem voz ativa.

\subsubsection{Violência de gênero: outros envolvidos}

Para os profissionais de saúde, quando há violência no espaço doméstico, os mais atingidos são as mulheres e as crianças. Esses que vivenciam relações de violência doméstica, seguramente serão afetados em alguma medida.

(Discurso do grupo) 0 nosso grupo fez um painel da representação da violência doméstica, por exemplo, aquela primeira mulher com o nenê no colo é representação de que geralmente a violência doméstica, recai sempre em cima da mulher e da criança, são as mais prejudicadas.

(Discurso do grupo) Tudo sobrecarrega nela e nessa criança sozinha, mostrando também que, na cabeça da criança, quando ela vive a violência doméstica, quando ela presencia, acaba reproduzindo na vida dela.

(Discurso do grupo) A criança, porque quando há violência no lar, quem sofre mais são as crianças e só nelas está a esperança, para que nós comecemos a educá-las pra melhorar. 
É possível que a violência familiar na infância, alterando a estrutura da personalidade e contribuindo para a destruição da auto-estima, permita o exagero da tendência à repetição dos padrões, fazendo com que as mulheres procurem parceiros que se assemelhem, em vários quesitos consumo de álcool, comportamento violento - aos seus pais agressores (Menezes et al., 2003).

Para Grossi, a saúde das vítimas de violência familiar é mais afetada em relação à população em geral. O maior problema está na saúde mental de mulheres, pois em relacionamentos violentos, elas estão cinco vezes mais predispostas a apresentar problemas psicológicos em relação às que não estão. Na saúde da criança, o impacto é visível na área emocional, cognitiva e comportamental. Os sintomas apresentados são: baixa autoestima e senso de competência, insegurança, medo, ansiedade, culpa. Sentem-se responsáveis pela violência, expressando isso mediante isolamento ou comportamento violento e destrutivo. Crianças vitimizadas podem ter pesadelos e distúrbios do sono, incontinência urinária, cacoetes e até tentar suicídio (Grossi,1996).

Em geral, mulheres que apresentam história de violência na família quando crianças, ou seja, que testemunharam atos violentos entre seus pais ou substitutos, tendem a apresentar maior tolerância à violência dos seus parceiros, por aceitarem como normais formas violentas na resolução de conflitos. E também homens, submetidos à violência, não são resilientes. Mulheres e homens que foram expostos a situações violentas apresentam seqüelas desses eventos. O fenômeno da resiliência é muito raro. "São resilientes pessoas capazes de viver terríveis dramas, sem, contudo, apresentarem um só indício de traumas" (Saffioti, 2004:18). Essa, no entanto, é uma condição excepcional, rara, em que o sujeito não se deixa afetar pelo trauma. Isso não se aplica, necessariamente, para algumas mulheres e alguns homens que sofrem, muitas vezes, repetidos traumas e inevitavelmente voltam a se expor a novos riscos. 


\subsubsection{Violência e drogadição - a combinação ideal da subalternidade}

Os profissionais de saúde relatam que o uso do álcool e outras drogas é responsável pela violência exercida contra as mulheres. De fato, o uso de álcool e outras drogas exacerbam a violência, especificamente o álcool, quando atua como um desinibidor, permitindo a liberação da tensão interna, criando uma sensação de onipotência. A preocupação dos profissionais de saúde revela que o álcool e a droga estão presentes e são recorrentes também no contexto social local.

(Discurso do grupo) (...) pensando na minha microárea, muito problemática a respeito do alcoolismo, nós temos clientes que são violentadas por causa do alcoolismo.

(Discurso do grupo) (...) representando às drogas, em com uma coisa bem pequena pode dar inicio a uma grande violência, como têm vários casos.

(Discurso do grupo) (...) na maioria das vezes a família é destruída devido ao uso de bebida alcoólica, então as pessoas não sabem usar e aí começa a agressão.

Para Adeodato et al. (2005) o alcoolismo foi apontado como um dos principais elementos desencadeador das agressões, principalmente as que ocorrem nos finais de semana ou à noite, quando o agressor está dentro de casa. Para Saffioti, embora o álcool exacerbe a violência, de modo algum podemos afirmar que seu uso responde por ela,

"o álcool constitui mais um pretexto do que causa de espancamentos e assassinatos de mulheres e/ou crianças. Rigorosamente, o alcoolismo não responde pela violência, mesmo porque um número imenso de homens pratica violência de gênero (contra a mulher) em condições de sobriedade" (Saffioti, 1995:5).

É relevante também dizer que o uso de drogas pode ocorrer não apenas entre os agressores, mas também entre as vítimas. $O$ beber feminino engloba o processo de lidar com experiências adversas e fugir do 
sofrimento, resistindo à violência e ao desamparo, numa tentativa de ficar alegre e mais sociável. Revela-se assim, ao mesmo tempo, um beber que é solitário, depressivo e autodestrutivo (César, 2005).

Assim, é possível que a maior vitimização das mulheres alcoolizadas ou drogadas se deva ao fato de que elas sofrem mais preconceito social. Os lares ainda são os locais mais usados pelas mulheres para o consumo dos entorpecentes, ao contrário dos homens, que têm um beber menos solitário e mais público. Da mesma maneira, a incidência do tabagismo em mulheres encontra-se relacionada com a tendência dessas desenvolverem comportamentos de risco para a sua saúde (Menezes et al., 2003).

Além do álcool, muitas mulheres costumam fazer uso de drogas medicamentosas. Nos discursos a seguir os profissionais referem que muitas mulheres que sofrem violência fazem uso de drogas prescritas, ansiolíticos, antidepressivos, hipnóticos etc. Eles criticam esse uso pois, no seu entender, isso contribui para que a mulher fique calma e não reaja. Certamente, esses medicamentos mantêm a violência encoberta, e o alívio momentâneo serve apenas como fuga do problema, pois essas drogas não solucionam o problema.

(Discurso do grupo) geralmente as mulheres tomam muito calmante. Procuram nas drogas uma forma de se acalmar, mas não reagem, só ficam no calmante.

(Discurso do grupo) (...) porque muitas vezes nas visitas que percebemos que muitas mulheres tomam tranqüilizantes, para tentar se esconder da violência, assim do tipo o marido alcoólatra, que não trabalha, não supre as necessidades e elas acabam se escondendo atrás de tranqüilizantes para, em vez de mudar a historia, elas se escondem atrás disso.

Alguns autores também desaprovam a indicação desse tipo de prescrição, entendendo que em casos de agressão, esses remédios deveriam ser evitados, uma vez que deixam as mulheres mais sonolentas, diminuem seus reflexos, sua capacidade de pensar e reagir e provocam dependência (Heise et al., 1999).

Para a Organização Panamericana de Saúde (2003), a menos que seja necessário, devem-se evitar tranqüilizantes e medicamentos 
modificadores do estado de ânimo à mulheres, cujos companheiros sejam agressores, pois esses remédios podem diminuir a capacidade delas de prevenir-se de ataques e de reagir a eles (Organización Panamericana de la Salud, 2003).

Para Grossi, há também falta de sensibilidade dos profissionais para ouvi-las e assim, conhecer a sua história de vida. Muitas vezes, apesar de serem medicadas com tranqüilizantes, o problema persiste (Grossi, 1996).

Para Silva, o atendimento na unidade de saúde não pode se resumir a uma prática medicalizadora, limitada à prescrição de analgésicos e tranqüilizantes. É necessário que haja compromisso de considerar os aspectos sociais que se acham relacionados com o processo de adoecer, respeitando as peculiaridades de cada ser humano. Há necessidade de se ter uma preocupação maior, um olhar diferenciado por parte dos profissionais de saúde, responsáveis pelo atendimento a essas mulheres que recorrem à unidade de saúde em busca de ajuda (Silva, 2003).

Em contrapartida, em ferimentos aparentes, causados pela violência física, as drogas prescritas são aceitas pelos profissionais. Essas lesões chocam, expõem a dor e diante do sofrimento e da obviedade, a administração justifica sua indicação.

(Discurso do grupo) (...) essa caixinha, a respeito do medicamento, de amenizar uma dor ou, numa situação de assistência, de enfermagem, pois de repente seria prescrito alguma coisa e você pode tentar ajudar nessa situação física.

Em se tratando de violência física, a intenção da prescrição do medicamento é vista como positiva pelos profissionais da saúde. No entender deles, nessas situações, o remédio trará alívio à mulher, ao sentimento exposto por ela.

(Discurso do grupo) quando há uma agressão física na mulher, ela vai sentir dor, ela toma remédio pra passar a dor.

Alguns profissionais não se mostram tão complacentes com esta conduta, pois percebem que a sensibilidade surte mais efeito. Pela vivência e pela experiência acumulada em atendimentos a mulheres agredidas, os 
profissionais empiricamente observam que estar sensível ao fenômeno abre possibilidades, inclusive de escuta. Nesse caso, o remédio é visto por eles como um vilão, um paliativo que apenas posterga o problema, podendo até silenciá-la. Além disso, sinaliza uma futura procura da mulher pelo serviço.

(Discurso do grupo) A medicação: pela vivência que eu tenho de sete anos no pronto-atendimento, às vezes, o profissional médico não tem a sensibilidade que nós temos. Então, quando chega alguma mulher violentada ele se preocupa só em tirar a dor, medicar e liberar essa mulher para casa. Então a medicação, de uma forma negativa, não está resolvendo o problema dessa mulher.

Por não resolver seu problema com o uso de remédios, as mulheres agredidas comparecem ao serviço de saúde inúmeras vezes com diferentes queixas e por causa disso, no local é denominada "poliqueixosa" (Schraiber, Oliveira, 2003).

Muitas vezes, a essas mulheres os profissionais também agregam outras denominações pejorativas, tais como: polissintomáticas e hipocondríacas (Kronbauer, Meneghel, 2005).

\subsection{5 $O$ atendimento à mulher em situação de violência: entre a (im)possibilidade e o acolhimento}

Quando sofrem agressões, as mulheres chegam aos serviços de saúde e, em geral, não expõem o que se passa, pois mesmo elas têm dificuldade de defini-lo. A violência de gênero envolve muitas demandas, mas nem por isso ela é evidente, até por que, por medo ou vergonha, as mulheres mantêm-na em segredo. Acreditam tratar-se de assunto privado e se sentem culpadas por não conseguirem suprir as necessidades do companheiro, que constantemente lhes afirma isso.

Diante disso, nos atendimentos, os profissionais se deparam com situações inesperadas. À medida em vão investigando, os problemas vão 
aparecendo e de certa maneira se avolumando, pois os casos que envolvem violência de gênero carregam outros problemas como a dependência, o amor-desamor pelos filhos, as dificuldades para manutenção do casamento e outros. Os profissionais então, associam a situação, a uma bola de neve.

(Discurso do grupo) Uma bola, numa bola de neve, pensando que quando atendemos a pessoa, pensamos que é uma coisa, mas quando você vê, desencadeia um monte de outras coisas juntas, e vai aumentando, então a bola representa isso.

O desconforto sentido pelos profissionais durante 0 atendimento à mulher agredida pode ter sua origem na insegurança do novo e do desconhecido, referido por eles como uma caixinha surpresa. Essa incógnita, tanto pode ser boa, diante de um problema conhecido ou de fácil solução ou ruim quando eles se defrontam com algo de difícil solução.

(Discurso do grupo) A caixa de presentes como se fosse uma caixinha surpresa, pois a pessoa que aparece para nós pode ser uma surpresa boa, pode ser uma surpresa ruim.

Nessa fala, os profissionais exprimem a sensação de não dar conta de tantas queixas. Não são apenas os profissionais de saúde de Araraquara que expõem tal dificuldade, esse sentimento já foi descrito, em trabalho anterior, como se fosse a abertura da caixa de Pandora (Kronbauer, Meneghel, 2005). Oriunda da mitologia grega, essa expressão é utilizada para designar qualquer coisa que incita a curiosidade, mas na qual é preferível não tocar, pois expõe os males do mundo.

Quando as mulheres procuram ajuda, expondo a violência no atendimento expõem inúmeras situações-problema que os profissionais de saúde não conseguem abordar, a despeito das expectativas de ambos.

$\mathrm{Na}$ fala a seguir, os profissionais dizem-se espectadores por se sentirem mexendo numa situação de difícil controle, apesar de potencialmente ser passível de mudança. Evidenciam a expectativa da mulher, mas não conseguem avaliá-la. É difícil prever o desfecho, mas em havendo oportunidade de prestar ajuda, ela não deve ser desperdiçada, pois as mulheres têm muita dificuldade de falar sobre isso. Se não atendidas, podem abandonar o serviço. 
Além disso, acreditam que a mulher quando procura o serviço de saúde não quer ajuda, porque não leva adiante a denúncia feita à polícia. Desta forma, ao acreditar que a única ajuda possível seria a jurídica, revelam-se presos às concepções ortodoxas que prescrevem unicamente o rompimento como solução para a violência de gênero.

(Discurso do grupo) Existe muita expectativa, mas não se sabe o que há de expectativa do outro também. Então, pode ser uma bomba que explode ou pode apagar o fogo; enfim, uma expectativa tanto para o bem quanto para o mal, pode ser usada dos dois jeitos.

(Discurso do grupo) (...) depois que a mulher é agredida, ela procura, mas ela não quer ajuda, ela não quer que o caso chegue até a polícia, não quer por medo. Então nós ficamos de mãos atadas também, é como se amarrassem nossas mãos e nossas atitudes, porque ficamos sem saber o que fazer.

As respostas às demandas apresentadas pelas mulheres em situação de violência doméstica são muitas, como: atenção psicológica, direito civil, trabalho, moradia, creche, escola, enfim, um mundo de necessidades derivadas do desrespeito sistemático aos direitos humanos, à cidadania e a conseqüente vulnerabilidade alta dessas mulheres e meninas aos agravos biopsico e sociais, demandas estas que vão além da esfera criminal (Schraiber et al., 2005).

Além da dificuldade financeira a que estariam expostas, a impunidade, o medo, a dependência emocional e o constrangimento de ter a sua vida revelada, são motivos que fazem com que muitas desistam da denúncia policial ou de seguir com a ação penal.

"O preconceito e o despreparo das autoridades e funcionários em atender a mulher violentada, também são barreiras que dificultam o acesso destas à justiça, já que muitas vezes são tidas como causadoras da situação que gerou a violência" (Garbin et al., 2006:2568).

Esses sentimentos refletem a submissão construída socialmente para as mulheres. Entre outras coisas, elas não notificam as agressões por considerarem-se inferiores ao agressor (Garbin et al., 2006).

Mesmo entre aquelas que passaram por situação de violência, algumas mulheres não o consideram motivo suficiente para uma punição 
mais severa do agressor, principalmente se o fato ocorreu sob a forma de ameaças, sem a prática da violência física (Silva, 2003).

Para os profissionais de saúde, em geral, a equipe não sabe lidar com casos envolvendo violência de gênero. Admitem que há muito o que aprender em relação ao tema. Vários estudos realizados no âmbito do PSF mostram o despreparo e a impotência dos profissionais em relação a este tipo de assistência, admitindo que há muito a aprender sobre violência de gênero e assim preparar-se para o atendimento. $O$ despreparo, que gera impotência, aliado à falta de tempo, de recursos, medo de ofender a mulher ao perguntar, são fatores já considerados em outros estudos (Kronbauer, Meneghel, 2005; Schraiber et al., 2005).

Sobre a falta de preparo, o trabalho realizado por Oliveira, evidenciou a fragilidade dos profissionais diante das demandas advindas de situações de violência em geral, principalmente de violência sexual contra a mulher. Para tanto, não basta o treinamento em técnicas e aplicações de alguns protocolos. É preciso incluir espaços mais reflexivos que possibilitem ampliar o conhecimento acerca da violência de gênero e seus determinantes, entre eles os conceitos de dominação - subalternidade e suas conseqüências (Oliveira, 2005).

(Discurso do grupo) (...) a falta de preparo de alguns profissionais, mesmo de PSF. Não é porque é PSF que todo mundo é dez ou mil, ainda há muito que aprender em relação a grupo, em relação à pessoa, a respeito, a acolher.

(Discurso do grupo) (...) falta de preparo dos profissionais, que às vezes, os profissionais querem ajudar, mas eles não estão preparados para isso.

Na fala a seguir, a impotência dos profissionais é tanta, que beira a resignação...

(Discurso do grupo) (...) pensando no bem-estar dela porque, depois de uma briga, depois de ter apanhado, nada como uma música, uma boa música, já que a gente não pode fazer nada mesmo, ouvir uma boa música pra ficar feliz, nem que seja um pouquinho.

A ausência de espaço físico adequado que propicie às mulheres a privacidade necessária para a verbalização da violência foi referida pelo 
grupo como uma preocupação, pois, nessa situação, elas se encontram fragilizadas, vulneráveis demais para confiar e o espaço, nesse caso, deve representar segurança, sigilo.

(Discurso do grupo) O espaço físico inadequado e muitas vezes a pessoa tem medo de se expor, de expor o problema.

Um estudo testou prospectivamente o conforto de 40 mães, com pelo menos um filho de 3 a 12 anos, sobre rastreamento de violência doméstica e mostrou que elas ficavam mais confortáveis em responder às questões sozinhas do que na presença das crianças, especialmente com relação a risco sexual e depressão. Elas expressam facilidade de falar em violência doméstica com médicos que criam um ambiente amigável e humano na consulta, além de informal. As questões mais abertas e vagas propiciam a elas sinalizarem que há algo errado, e que, posteriormente pode ser discutido, na ausência da criança. Ir da questão mais geral para a mais específica é mais confortável para essas mulheres (Zink et al., 2006).

\subsubsection{O acolhimento e a escuta qualificada}

O atendimento no PSF se baseia na promoção da saúde e na prevenção de doenças, além de tratar os agravos mais comuns. Um de seus princípios fundamentais é a atenção integral e humanizada. Uma das ações para a humanização da atenção é o acolhimento, receber bem, dar respostas às necessidades de saúde da população. Nas falas a seguir, os profissionais referem-se ao acolhimento com a disposição da escuta para acalmar a mulher agredida, como ação pontual para, em seguida, dar prosseguimento à assistência.

(Discurso do grupo) A assistência que a gente tem é o acolhimento, a escuta, escutar tudo que ela tem pra falar e a gente dar também apoio psicológico e encaminhar ela para o centro de referência. 
Em outra fala, o atendimento vai até no que for preciso para ajudá-la, mas encerra-se no sentido de acalmá-la para, em seguida, encaminhá-la ao Centro de Referência da Mulher. Ao que tudo indica, resume-se a isso a assistência.

(Discurso do grupo) (..) união entre a pessoa violentada ou agredida com o atendimento dos profissionais da Unidade, no que for preciso para ajudá-la. Copo d'água com açúcar representando, o acolhimento, na tentativa de acalmar e também encaminhar a órgão do centro de referência.

Segundo os profissionais de saúde, o acolhimento consiste em passar credibilidade, confiança, na tentativa de fazê-la falar sobre a violência. É estar presente, apoiar a mulher, sem, no entanto, dizer a ela o que deve fazer, sem aconselhar.

(Discurso do grupo) (...) depois que ela chegou pra conversar, é o acolhimento, a credibilidade que ela tem para se abrir, a confiança e a escuta.

(Discurso do grupo) (...) nós buscamos oferecer apoio, carinho e também estar presente.

(Discurso do grupo) Tem situação em que você precisa ajudar, mas também não aconselhar, porque às vezes você não sabe se esse aconselhamento que você vai fazer é o melhor remédio, a melhor solução ali.

(Discurso do grupo) (...) devemos recebê-la, na unidade de coração aberto, ouvindo-a falar, colocar tudo para fora. Nunca desrespeitar o que ela está falando, cortar a conversa dela pelo meio, então deixá-la falar a vontade. Valorizar a sua queixa naquele momento, para ela se sentir acolhida.

(Discurso do grupo) Esse laço, numa situação dessa dentro da Unidade o que deve acontecer é ter acolhimento, aquela coisa do laço mesmo com aquela pessoa, dando espaço pra ela falar, é o acolhimento mesmo.

Para Schraiber et al., na atividade de escuta e orientação, trata-se de criar um espaço onde a mulher possa compartilhar suas dúvidas, anseios, temores, expectativas e incertezas, onde possa falar de si e de como é afetada pelas situações de violência, falar das conseqüências para a sua saúde e ousar tecer rotas de mudanças - transformações da violência em novas formas relacionais, com rupturas das atuais relações ou com 
recuperação/instauração de interações, com os quais está em situação de violência (Schraiber et al., 2001).

\begin{abstract}
"As mulheres em situação de violência de gênero procuram mais os serviços de saúde e falam sobre as violências que sofrem, desde que se dê a elas a condições de acolhimento e escuta. Portanto, recomenda-se que os serviços de atenção primária em saúde criam espaços para ouvir, entender e enfrentar a violência de gênero" (Kronbauer, Meneghel, 2005:701).
\end{abstract}

Assim,

"o maior desafio dos profissionais da estratégia da saúde da família é concretizar, na prática cotidiana, a superação do monopólio do diagnóstico de necessidades e de se integrar à 'voz do outro', que é mais a construção de um vínculo/responsabilização. Traduzindo-se em uma efetiva mudança na relação de poder técnico-usuário, evidenciando o ser social, com vida plena e digna com expressão de seu direito" (Gomes e Pinheiro, 2005:298).

Os profissionais se referem à empatia, ou seja, identificar-se com o outro, colocando-se no lugar do outro e, com base em suas próprias suposições ou impressões, tenta compreender o comportamento do outro. Mas, para além da empatia durante o acolhimento estão as dificuldades, o que de fato acontece é que assistir mulheres em suas relações de violência não tem se mostrado tarefa fácil para os profissionais envolvidos com essa problemática.

(Discurso do grupo) Nós pensamos no acolhimento, na compreensão no ser empático, ouvi-la, chamando-a para uma sala, num espaço fechado pra você poder conversar com ela, jamais dizendo o que ela deve fazer, ou como agir, considerando aquele velho ditado que diz: "em briga de marido e mulher ninguém mete a colher."

Em relação ao acolhimento, as falas ainda revelam que mesmo a percepção deles de que a mulher esteja sendo agredida, não garante a confirmação por parte dela. A abordagem insistente pode afastá-la e o respeito ao silêncio é importante, pois como referem os profissionais, forçála é outra violência pois os processos que ela tem vivenciado têm por base exatamente a força. Assim, os profissionais devem respeitar o ritmo da 
mulher, mostrando-se sempre disponíveis para a escuta comprometida e qualificada.

(Discurso do grupo) Às vezes, percebemos que ela foi vítima de violência, muitas vezes ela nega, a gente não pode interferir também no pessoal dela, se ela quiser, nós até podemos tentar, porque estamos vendo, mas se a pessoa nega, nega, nega... Nós também não temos o direito de forçá-la a falar o que ela não quer, porque essa é outra violência.

No que se refere ao PSF, a proximidade dos agentes comunitários de saúde com a comunidade e com as famílias atendidas, os predispõem ao acolhimento de casos de violência de gênero, que ocorre no espaço doméstico. Mediante o vínculo estabelecido com as mulheres, são capazes de captarem que há algo diferente. Esse vínculo, para eles, é também uma porta facilitadora para que a mulher rompa o silêncio.

(Discurso do grupo) Nós colocamos também essa questão da estrutura do PSF, e o trabalho do ACS, do agente comunitário de saúde, ele está mais voltado para acolher esses casos. Por conta do vínculo, quando chegamos na casa já percebemos alguma coisa diferente, a pessoa já conta.

Em outra fala, o vínculo possibilita a percepção do que ocorreu na noite anterior, embora dessa vez, esse mesmo vínculo não viabilize a fala.

(Discurso do grupo) Embora, muitas vezes fiquem fechadas, não querem se expor para que possamos ajudá-las. Quando chegamos na casa, só no olhar a gente conhece o que ela está passando, o que ela passou na noite anterior.

Para Hartigan (1997) a primeira intervenção é o reconhecimento da violência doméstica. Entender a situação é uma forma de romper o isolamento e informar-lhe dos recursos disponíveis para ajudá-la quando ele se decidir. Como em outro lugar no mundo, na América Latina e no Caribe, as mulheres se encorajam a revelar a violência quando se sentem respaldadas e seguras. Por isso, a Opas reforça a importância dos profissionais de saúde perguntarem habitualmente para as mulheres sobre a violência doméstica (Hartigan, 1997).

Quando o Instituto Patrícia Galvão realizou, em setembro de 2004, o estudo sobre "O que a sociedade pensa sobre a violência contra as 
mulheres", também constatou que homens e mulheres de 16 anos ou mais, com diferentes níveis de escolaridade e renda, responderam com 91\% que consideram "muito grave 0 fato de mulheres serem agredidas por companheiros e maridos”. Em relação à gravidade do problema, as mulheres são mais enfáticas (com 94\%), mas $88 \%$ dos homens concordam com a gravidade. Ao mesmo tempo, grande parte acredita que não se deve interferir nos conflitos conjugais: o ditado "em briga de marido e mulher não se mete a colher", teve 66\% de aceitação (Instituto Patrícia Galvão, s/d). Ao não saberem como agir, não estariam os profissionais, de certa maneira, reforçando esta idéia?

Para Schraiber et al. (2005), a qualidade do cuidado recebido é muito importante. Ressaltam que o encorajamento, a informação precisa, o nãojulgamento e o respeito às decisões da mulher contribuem para a continuidade da rota, enquanto o descaso, a burocracia e a dificuldade de acesso podem ser grandes inibidores. A rota citada é composta pelo conjunto de decisões tomadas por mulheres que vivem situações de violências e suas ações para lidar com o problema. O estudo identificou fatores que podem facilitar ou dificultar o atendimento.

\section{Fatores facilitadores}

\begin{tabular}{|l|l|}
\hline \multicolumn{1}{|c|}{ Internos } & \multicolumn{1}{c|}{ Externos } \\
\hline - Convencimento de que os recursos & - A própria violência contra ela \\
pessoais se esgotaram & - A violência contra filhos e filhas \\
- Saturação com situação & - Apoio de pessoas próximas \\
- Convencimento de que o agressor não vai & - Condições econômicas e materiais \\
mudar & favoráveis \\
- Raiva e desamor & - Informação precisa e serviços de qualidade \\
- Colocar-se metas e projetos próprios & \\
\hline
\end{tabular}

(Schraiber et al., 2005:127/128)

\section{Fatores obstaculizadores}

\begin{tabular}{|l|l|}
\hline \multicolumn{1}{|c|}{ Internos } & \multicolumn{1}{c|}{ Externos } \\
\hline - Medos & - Pressões familiares e sociais \\
- Culpa & - Insegurança econômica e falta de recursos \\
- Vergonha & materiais \\
\hline
\end{tabular}




\begin{tabular}{|l|l|}
\hline - Amor pelo agressor & - Atitudes negativas dos profissionais e \\
- Idéia de que o que ocorre no interior da & respostas institucionais inadequadas \\
família é privado & - Limitada cobertura de organizações não- \\
- Manipulação do agressor e dinâmica do & governamentais e governamentais de \\
ciclo da violência & mulheres \\
- Desconhecimento de seus direitos e falta & - Contextos sociais com história de violência \\
de informação &
\end{tabular}

(Schraiber et al., 2005:127/128)

O medo do agressor é muito referido pelas mulheres agredidas como um grande elemento dificultante do enfrentamento da violência. Esse mesmo sentimento atribuído à mulher é compartilhado pelos profissionais da saúde no temor pela sua integridade física. Eles sentem-se muito expostos pela proximidade com a comunidade, além de inseguros ao atenderem esses casos, pelas probabilidades de perigo.

(Discurso do grupo) (...) a dificuldade que temos, às vezes, de lidar com o problema, ter medo da situação. O medo de que, futuramente, o agressor possa se voltar contra a pessoa que visita a casa, o ACS ou contra a Unidade da Saúde ou contra outro profissional que trabalha ali, essa pessoa ir lá com a intenção de querer causar algum mal.

Os profissionais devem estar conscientes do impacto desse medo e de acordo com o próprio Ministério da Saúde, é preciso criar oportunidades sistemáticas de discussões, sensibilização e capacitação para que a equipe possa expor e trabalhar sentimentos e reações. "O contato com situações de sofrimento e risco, a insegurança e os questionamentos que despertam, bem como a impotência em obter soluções imediatas, exigem um tempo de autodeterminação para proteção e alívio de tensões” (Brasil, 2001:31).

Para os profissionais, ainda, as perspectivas de ruptura das situações de violência estão nas crianças, em mulheres mais novas, adolescentes. Quando dizem isso, não mencionam a participação do homem na educação, ignorando que a violência seja um problema relacional de gênero.

(Discurso do grupo) Tentar educar as crianças, as mulheres mais novas, adolescentes, começar educar para que elas não perpetuem aquilo que as mães delas estão sofrendo. 
(Discurso do grupo) Temos que trabalhar com aqueles que vêm vindo para ter um futuro melhor; nós sabemos que qualquer mudança pode ser lenta, gradual, demorada, mas um dia chega, e nós não podemos desistir.

Ocorre que, em se tratando de violência de gênero, a tarefa educacional envolvendo as crianças não é tão fácil, pois persistem, mesmo nas escolas o preconceito e a discriminação de gênero. Para Souza (2004), o preconceito e a descriminação de gênero para muitos profissionais, nas mais diversas áreas do Brasil, é preocupante. Na área educacional mais ainda, pois é um espaço de reflexão e transformação das crenças e dos valores. Em pesquisa exploratória realizada com 28 crianças entre 10 e 11 anos (18 meninas e 10 meninos), de escola pública, periférica, em Assis, no interior de São Paulo, todos cursando $4^{\underline{a}}$ série do ensino fundamental, a pesquisadora orientou crianças a escreverem sobre o que é ser menina e o que é ser menino. Entre outras coisas, ela concluiu que as meninas concentram-se na fragilidade e na preocupação em dar carinho e cuidar dos outros. Quando descrevem seus papéis, as crianças o fazem a partir da vivência. As características em ambos são vistas dicotomizadas com referência à construção de valores do masculino e do feminino. Ambos descrevem de maneira exemplar seus papéis, as meninas assumem que as responsabilidades são suas, enquanto eles se concentram em brincadeiras, porém referem que as meninas são emocionalmente mais maduras. Para o autor, há uma reprodução da ideologia de gênero e a complexidade que envolve a abstração dos elementos pelas(os) participantes está relacionada à suas histórias de vida e, em relação à temática de gênero (Souza, 2004).

Para Louro, "a escola é atravessada pelos gêneros; é impossível pensar sobre a instituição sem que se lance mão das reflexões sobre as construções sociais e culturais de masculino e feminino" (Louro, 1997:89).

\subsubsection{O preconceito reconhecido como barreira à assistência}


Os profissionais ainda reconhecem que eles mesmos vivem sob valores culturais e enfrentam os mesmos problemas semelhantes aos das mulheres e, conseqüentemente, podem ser afetados pelas questões de gênero e da cultura. Eles admitem uma interposição de barreira, não só no que verbalizam, mas principalmente, no que demonstram com sua postura, seu olhar. Citam também o preconceito, reconhecendo que esse está incorporado, embutido na cultura. O preconceito como barreira se interpõe quando algo ou alguém é conceituado com base em julgamento ou em opinião concebida previamente. Esse julgamento é formado sem fundamento justo e sem o conhecimento suficiente. Quando admitem o preconceito, os profissionais referem-se ao diferente, pois na construção social, eles têm como preceito, como norma, o sujeito padronizado. Mas, conscientes dos prejuízos que os preconceitos causam ao atendimento, eles evidenciam a necessidade de revê-los primeiro, para depois, atender ou intervir.

O preconceito mostra-se como barreira às possibilidades, à capacidade de efetivação da assistência. Os profissionais reconhecem que contribuem de muitas formas para que barreiras, como o preconceito, sejam criadas e mantidas; entre as citadas: da postura (corpo), pois o corpo fala, ele exibe nossa receptividade; o olhar - pode ser o da reprovação ou aquele que ignora - mas também aquele que encoraja. Encontra-se em imagens, linguagens, nas marcas corporais e psicológicas, nos gestos e nos espaços, etc.

(Discurso do grupo) A lata aberta é a exposição da situação. Um pote fechado significa a impotência, o preconceito dos profissionais.

(Discurso do grupo) (...) às vezes, não é só a fala do profissional que é importante, não é só o que ele está dizendo, mas o que ele demonstra na postura, no olhar, na barreira que ele coloca, então nós achamos que é uma fragilidade o preconceito, até em relação ao homossexualismo. Preconceito que nós temos, às vezes, embutido e nós. Temos que lidar conosco mesmos, porque é alguma coisa que a gente não está acostumado a ver, que choca: que temos, primeiro, de lidar conosco, para depois conseguir trabalhar 0 outro. 
Para Bandeira e Batista, "O preconceito caracteriza-se como sendo uma forma arbitrária de pensar e de agir, no sentido de que é exercido como uma forma racionalizada de controle social que serve para manter as distâncias e as diferenças sociais entre um sujeito e outro ou o/um grupo" (Bandeira, Batista, 2002:130).

Implica uma relação social, uma maneira de relacionar-se com o diferente, negando-o ou desvalorizando-o na sua identidade; supervalorizando-o ou também como afirmação da própria identificação.

Para as autoras, o pensamento passa pelo corpo inteiro, não apenas na esfera do racional, todas nas formas de conhecer o outro, passam pelo preconceito. $\mathrm{O}$ eu não consegue apropriar-se daquele que representa a diferença, a alteridade.

Essa forma de pensar destaca traços de inferioridade, acarreta práticas e atribuições arbitrárias, baseados em argumentos irreais do comportamento das pessoas, que são objetos da discriminação (Bandeira, Batista, 2002). 


\section{CONSIDERAÇÕES FINAIS}

O trabalho analisou concepções dos profissionais de saúde do Programa de Saúde da Família de Araraquara acerca da violência de gênero, respaldado na visão de homem e de mulher. A despeito de ser um grupo onde já se percebem avanços no sentido de uma visão mais crítica a respeito da influência dos processos de construção da masculinidade e da feminilidade na identidade de gênero, coexistem com esta, visões conservadoras que reafirmam as estereotipias condizentes com o senso comum, reveladas, por exemplo, na concepção de homem-provedor (racional, forte, o que deve mandar), mulher-reprodutora (emocional, frágil, a que deve obedecer), que nada mais são que o reforço dos papéis estabelecidos socialmente.

llustram as visões mais críticas, concepções reforçadoras da participação de homens no cuidado do filho, a crítica aos que proíbem as mulheres de estudar e aos que não participam do trabalho doméstico, reconhecendo o peso da dupla ou tripla jornada feminina.

Esse ponto de vista dualista de perceber mulheres e homens se deve porque mudanças estão acontecendo nas relações homem-mulher a partir da entrada das mulheres no mundo público, o que Ihes permitiu melhorar suas condições de autonomia. Ainda que essas mudanças não tenham sido radicais, elas operam também transformações na sua conduta e posicionamentos, tornando-se mais firmes nas relações que estabelecem com os homens, o que contribui para que aos poucos redefinam seus papéis de gênero no âmbito doméstico ou familiar. Esse movimento é sentido socialmente e colaboram para que transformações também ocorram na concepção de gênero dos sujeitos, uma vez que gênero é constituinte das identidades. Levando-se em conta que a subjetividade corresponde a época em que se vive, quando os profissionais se dividem em concepções de 
gênero mais tradicionais ou timidamente como mais inovadoras, mostram o seu repertório de gênero e isso demonstra que se tratam de sujeitos em construção.

Abordar a violência de gênero é entender questões que dizem respeito aos papéis sexuais e de gênero; à relação homem-mulher; à hierarquia de poder; à família como espaço privado onde se estabelecem normas, valores e atitudes, assim como ao espaço que regula a afetividade, a sexualidade e a vida individual; à educação diferenciada; às condições sócio-econômicas das mulheres; à situação social de domínio e privilégio do homem sobre a mulher nos aspectos econômicos e culturais; aos mitos de superioridade do homem e inferioridade da mulher, baseados no direito do homem de dominar a mulher. Isto porque a violência de gênero não ocorre desvinculada de todo o processo social que coloca homens e mulheres em relação.

Em se considerando as sobreposições das categorias, gênero, raça/etnia, geração, classe social, que constituem relações de poder e que se revelam hierarquicamente, essas sobreposições se constituem pelo movimento histórico da humanidade. A combinação entre elas resulta em inúmeras hierarquias existentes. A realidade da violência de gênero pelos profissionais de saúde desta pesquisa é percebida como um problema cultural e complexo, enraizado na sociedade, porém eles não referem que essa cultura responde por um sistema que aceita a superioridade do homem e a subordinação da mulher, ou seja, a dominação e o poder dele sobre as decisões e a vida dela. Segundo a visão dos profissionais, não se trata de um fenômeno relacional, mas de um fenômeno onde a mulher é vista como vítima e o homem como algoz. Porém, o que eles não percebem é que ao mesmo tempo em que a vítima é louvada pelo reconhecimento do sofrimento, reduzem-se drasticamente as possibilidades de superação da violência.

A violência de gênero evidenciada pelos profissionais do PSF encontra-se relacionada com o uso abuso de álcool e de drogas pelos 
homens, afetando o cotidiano das famílias, provocando a deteriorização das relações e causando problemas nas comunidades onde residem. Quanto às famílias atendidas, essa preocupação se expressa também na violência contra a criança no âmbito doméstico.

No que diz respeito à violência de gênero como problema recentemente colocado na agenda da saúde pública apesar dos serviços de saúde se confrontaram há muito tempo com essa realidade, os profissionais confirmam que as mulheres agredidas procuram atendimento tanto pelas conseqüências diretas das agressões como pelas conseqüências indiretas, traduzidas em agravos à saúde. O que elas nem sempre fazem é relatar as situações vivenciadas, exceto quando a escuta qualificada do profissional abre possibilidades para isto. Nesse sentido, é de especial relevância as condições do atendimento traduzidas no que eles chamam de acolhimento como a maneira mais sensível e adequada de abrir espaço para a detecção ou o enfrentamento da violência de gênero.

Garantir às mulheres o acesso à educação e ao trabalho, foram medidas assinaladas pelos profissionais como muito importantes para o enfrentamento da violência de gênero e conseqüente melhoria da qualidade de vida. Nesse sentido, as falas dos profissionais enfatizam a importância da independência econômica das mulheres e o incentivo a elas estudarem como possíveis elementos de transformações das relações homem-mulher, a fim de que elas se posicionem de maneira mais igualitária e com mais liberdade perante o homem, adotando posições mais autônomas, que thes permitam construir novas formas de parceria para enfrentar e superar as situações de violência. A educação, tanto para as mulheres como para as crianças são apontadas como questões fundamentais para fortalecê-las e transformarem as relações no futuro.

Discute-se a importância de que os serviços de saúde desenvolvam ações que não somente reparem o dano físico produzido, como também para que as intervenções sejam mais integrais. A violência de gênero necessita de uma abordagem mais ampla e multiprofissional para possibilitar 
às mulheres envolvidas o enfrentamento dessa realidade e a sua superação. Em Araraquara, é tida como de suma relevância a articulação com o Centro de Referência da Mulher para garantir atendimento especializado à mulher agredida. Nesse sentido, os profissionais de saúde conhecem o âmbito das suas ações e a importância da ação inter-setorial, embora reconheçam também que o próprio Programa de Saúde da Família tenha que avançar na promoção da saúde, o que significa desnaturalizar as situações de violência e percebê-las para além de um problema judicial. Além disso, a equipe deve ser instrumentalizada também para uma abordagem integral da família, pois na maioria dos casos é a mulher que procura o serviço de saúde, ou é ela que se encontra no domicílio quando é feita a visita domiciliária. Sabe-se que alguns homens se esquivam do contato com a equipe de Saúde da Família, mas sabe-se também que é necessário que eles sejam incluídos, assim como os demais sujeitos que fazem parte do grupo familiar para detectar nas relações pessoais as questões difusas que permeiam a dinâmica familiar. Procurar uma brecha para dar início à intervenção é visto como uma estratégia privilegiada de detecção de violência de gênero.

A comunidade também pode ser mobilizada no sentido de ser sensibilizada em relação à violência de gênero. Assim, o modelo de atuação mais integral, tal como proposto pelo PSF, pode influenciar positivamente para suspeitar e identificar a violência de gênero no âmbito doméstico. Segundo os profissionais, as próprias características do Programa lhes possibilitaram essa abordagem: atendem a uma determinada quantidade de famílias e, por isso, estabelecem relações mais próximas e estreitas com os moradores das comunidades nas quais se encontram inseridos. Essa característica, como os profissionais assinalaram, é a grande vantagem de trabalhar numa comunidade conhecida.

Nos depoimentos sobre as dificuldades de enfrentamento da violência de gênero, a idéia central é que os profissionais não se sentem preparados para o atendimento, a despeito da percepção de que se trata de um problema complexo e delicado que, ao ser abordado, se desdobra em outras 
questões. O sentimento de impotência, no entanto, não se faz presente como em outros estudos (Oliveira, 2005), porque reputam ao acolhimento e à sensibilidade demonstrada na maneira de lidar com as questões a qualidade da assistência prestada. Paradoxalmente, quando as mulheres silenciam sobre o problema, já não sabem o que fazer e para aliviar a tensão causada pelo não atendimento, recorrem às vezes a práticas não muito adequadas para a detecção das situações de violência como os comentários com as vizinhas ou similares.

Assim é que os profissionais do PSF de Araraquara percebem que as possibilidades de atuação dos serviços diante da violência de gênero apresentam limitações de várias ordens, dentre elas, as dificuldades deles mesmos, como profissionais, quando oscilam entre ter ou não segurança para atender. Reconhecem dificuldade para identificar a violência e atuar, e admitem fragilidades até mesmo quando reafirmam que fazem 0 acolhimento. Isto resulta em que verbalizam com muita ênfase a necessidade de qualificar-se para melhor responder aos atendimentos de violência de gênero, assim como para discutir e rever suas próprias concepções, posições e preconceitos.

É na estrutura que a violência de gênero insere-se mais amplamente, mas a organização social nesse trabalho não foi problematizada. Essa violência relaciona-se à diferença na remuneração, a pouca representatividade política, menores salários, em relação aos homens, apesar da maior escolaridade. Além disso, a condição de vulnerabilidade da mulher na sociedade é gerada pela desvalorização ou supervalorização do seu corpo, em desigualdades associadas às classes sociais, sobrecarga de trabalho e níveis inferiores de saúde e bem-estar. No presente trabalho, os profissionais não reconhecem a condição de vulnerabilidade social da mulher diante da violência simbólica. Para Saffioti, esse tipo de violência encontra-se diluído na sociedade; porque é intrínseca à organização de gênero, dela faz parte, é assim que funciona; está presente o tempo todo (Saffioti, 1999). 
Finalmente, há que se concluir que os profissionais das equipes de saúde da família do Município de Araraquara - em especial os agentes comunitários de saúde - do ponto de vista da violência de gênero, encontram-se aderentes a concepções que ao mesmo tempo em que reforçam o problema por reproduzirem as estereotipias, os preconceitos e as discriminações de gênero, apontam para a sua superação, muito por conta da sensibilidade para reconhecer a gravidade do fenômeno e a intensa vontade de ajudar as mulheres da coletividade, levando a cabo sua missão de estabelecer uma ponte entre elas e as suas necessidades, e o sistema de saúde.

Porém, apesar disso, ainda é relativamente frágil a concepção da violência de gênero como problema social, posto que a entendem mais como oriunda das relações no âmbito da singularidade, sem admitir a grande influência dos mecanismos sociais que permeiam as relações como a educação, a mídia, a religião etc. Dessa maneira, se faz necessário o quanto antes transformar esta visão dos profissionais para que efetivamente desloquem a sua determinação para a maneira como a sociedade impele homens e mulheres à construção da masculinidade e da feminilidade.Para finalizar, parece importante reafirmar que considerar a violência contra as mulheres como problema social implica não só uma maior visibilidade do problema como também uma forma especial de abordar a sua explicação. Assim, se desde a análise como problema individual se entendia esta violência como conseqüência de alguma situação ou circunstancia particular, a sua consideração como problema social compreende a visão de que a violência de gênero tem sua origem última nas relações sociais baseadas na desigualdade, em um contrato social entre homens e mulheres que implica a opressão de um gênero (o feminino) por parte do outro (o masculino). A partir dessa consideração, são necessárias atuações no nível social que impliquem um novo tipo de contrato social, com novas medidas legislativas, modificações nos programas educativos, entre outras, para enfrentar o problema e superar suas conseqüências (Fiol; Pérez, 2000). 


\section{REFERÊNCIAS BIBLIOGRÁFICAS}

Adeodato VG, Carvalho Rdos R, de Siqueira VR, de Matos e Souza FG. Qualidade de vida e depressão em mulheres vítimas de seus parceiros. [Quality of life and depression in women abused by their partners]. Rev Saude Publica. 2005;39(1):10813.

Almeida AM, Trindade RFC, Gomes FA, Nielsen L. Maternidade na adolescência: um desafio a ser enfrentado. [Maternity in adolescence: a challenge to be faced]. Rev Bras Enfermagem. 2003;56(5):519-22.

Alvarado R, Erazo C. Violencia conyugal según niveles socioeconómicos en Región Metropolitana. [Metropolitan region couple violence according to socioeconomic levels]. Rev Chil Salud Pública. 2002;6(1):27-35.

Alves R. A bisavó. [citado 2007 mar. 16]. Disponível em: http://www2.uol.com.br/aprendiz/n_colunas/r_alves/id120501.htm.

Alves AM, Coura Filho P. Avaliação das ações de atenção às mulheres sob violência no espaço familiar, atendidas no Centro de Apoio à Mulher (Belo Horizonte), entre 1996 e 1998. [Estimate of activity women's attention that are constrained in the family environment, Attentive in Centro de Apoio à Mulher (Center of Women's Support), in Belo Horizonte, between 1996-1998]. Ciênc Saúde Coletiva. 2001;6(1):243-57.

Andrade MC. Violência contra a mulher e exclusão social: estudo entre subgrupos de populações usuárias do Centro de Saúde Escola Barra Funda - Dr. Alexandre Vranjac [dissertação]. São Paulo: Faculdade de Medicina da Universidade de São Paulo; 2003.

Araújo MF, Martins EJS, Santos AL. Violência de gênero e violência contra a mulher. In: Araújo MF, Cecilato O, organizadores. Gênero e violência. São Paulo: Arte \& Ciência; 2004. p. 17-35.

Badinter E. Um amor conquistado: o mito do amor materno. Rio de Janeiro: Nova Fronteira; 1985.

Bandeira L, Batista AS. Preconceito e discriminação como expressões de violência. [Prejudice and Discrimination as Expressions of Violence]. Rev Estud Fem. 2002;10(1):119-41. 
Barker G, Nascimento M. Da violência para convivência. Rio de Janeiro: Promundo; 2001.

Barros MNF. Violência contra a mulher: as marcas do ressentimento. [Violence against the woman: the marks of the resentment]. PSI — Rev Psicol Soc Instit (Londrina). 2000[cited 2007 mar 16];2(2):129-48. Disponível em: http://www2.uel.br/ccb/psicologia/revista/index.htm.

Batista KBC. Violência contra a mulher e programa saúde da família: a emergência da demanda na visão dos profissionais [dissertação]. São Paulo: Faculdade de Medicina da Universidade de São Paulo; 2003.

Beauvoir S. A infância. In: Beauvoir S. O segundo sexo II: a experiência vivida. Trad. de Sérgio Milliet. São Paulo: Difusão Européia do livro; [1960]. Infância; p. $9-65$

Brasil. Ministério da Saúde. Construindo uma linguagem comum. In: Brasil. Ministério da Saúde. Secretaria de Políticas de Saúde. Violência intrafamiliar: orientações para a prática em serviço. Brasília: Ministério da Saúde; 2001. p. 13-22.

Brasil. Ministério da Saúde. Departamento de Atenção Básica. Atenção básica e a saúde da família. [atualizado em 2007 mar. 15; citado 2004]. Disponível em: http://dtr2004.saude.gov.br/dab/atencaobasica.php.

Brasil. Ministério da Saúde. Lidando com situações de violência. In: Brasil. Ministério da Saúde. Secretaria de Políticas de Saúde. Violência intrafamiliar: orientações para a prática em serviço. Brasília: Ministério da Saúde; 2001. p. 27-31.

Brasil. Presidência da República. Casa Civil. Subchefia para Assuntos Jurídicos. Lei $\mathrm{n}^{\mathrm{o}}$ 11.340, de 7 de agosto de 2006. Cria mecanismos para coibir a violência doméstica e familiar contra a mulher, nos termos do $\S 8^{0}$ do art. 226 da Constituição Federal, da Convenção sobre a Eliminação de Todas as Formas de Discriminação contra as Mulheres e da Convenção Interamericana para Prevenir, Punir e Erradicar a Violência contra a Mulher; dispõe sobre a criação dos Juizados de Violência Doméstica e Familiar contra a Mulher; altera o Código de Processo Penal, o Código Penal e a Lei de Execução Penal; e dá outras providências. Brasília, 7 de agosto de 2006; $185^{\circ}$ da Independência e 118ํㅡㄹ da República. [citado 200715 mar.]. Disponível em: http://www.planalto.gov.br/ccivil_03/_Ato20042006/2006/Lei/L11340.htm. 
Cabianca de Skaf G. Perfil bio-socio-sanitario de las madres adolescentes en la Provincia de Salta. [Bio-social and sanitary profile of adolescent mothers in the Province of Salta]. Diaeta (B. Aires). 2006;24(114):16-23.

Cabral MAA, Brancalhone PG. Representações da violência conjugal de 117 mulheres de Campinas-Brasil. [Representation of the domestic violence by 117 women of Campinas-Brazil]. J Bras Psiquiatr. 2000;49(8):277-85.

Carcedo Cabañas A, Sagot Rodríguez M. Femicidio en Costa Rica: balance mortal. [Femicide in Cosa Rica: mortal balance]. Med Leg Costa Rica. 2002;19(1):5-16.

Castañeda M. O machismo invisível. Malimpensa LC, tradutora São Paulo: A Girafa; 2006.

Castro R, Ruíz A. Prevalencia y severidad de la violencia contra mujeres embarazadas, México. [Prevalence and severity of domestic violence among pregnant women, Mexico]. Rev Saude Publica. 2004;38(1):62-70.

Cavalcanti LF, Gomes R, Minayo MCS. Representações sociais de profissionais de saúde sobre violência sexual contra a mulher: estudo em três maternidades públicas municipais do Rio de Janeiro, Brasil. [Social representations by health professionals of sexual violence against women: a study in three municipal public maternity hospitals in Rio de Janeiro, Brazil]. Cad Saúde Pública = Rep Public Health. 2006;22(1):31-9.

Cesar BAL. O beber feminino: a marca social do gênero feminino no alcoolismo em mulheres. [Female drinking: the social mark of the female sort in alcoholism in women] [dissertação]. Rio de Janeiro: Escola Nacional de Saúde Pública Sérgio Arouca; 2005.

Costa COM, Lima IC, Martins Júnior DF, Santos CAST, Araújo FPO, Assis DR. Gravidez na adolescência e co-responsabilidade paterna: trajetória sociodemográfica e atitudes com a gestação e a criança. [Adolescent pregnancy and paternal coresponsibility: socio-demographic background and attitudes towards the pregnancy and the child]. Ciênc Saúde Coletiva. 2005;10(3):719-27.

D’Oliveira, Ana Flávia Pires Lucas. Violência de gênero, necessidades de saúde e uso de serviços em atenção primária. [Gender violence, healthcare needs and the use of healthcare services] [tese]. São Paulo: Faculdade de Medicina da Universidade de São Paulo; 2000. 
D’Oliveira AFPL. Quem diz e o que se diz (falas de especialistas). Portal Violência contra a Mulher. [citado 2007 abr. 19]. Disponível em:

http://copodeleite.rits.org.br/apc-aa-patriciagalvao/home/noticias.shtml?x=94.

Dantas-Berger SM. Violência sexual contra mulheres: entre a (in)visibilidade e a banalização [dissertação]. Rio de Janeiro: Escola Nacional de Saúde Pública, Fundação Oswaldo Cruz; 2003.

Declaração de Viena e Programa de Ação. Conferência Mundial sobre os direitos do homem. Viena, 14-25 de julho de 1993. [citado 2007 abr. 17]. Disponível em: http://www.min-nestrangeiros.pt/politica/multilateral/politicas/cdhviena.html.

DeSouza E, Baldwin JR, Rosa FH. A construção social dos papéis sexuais femininos. Psicol Reflex Crit. 2000;12(3):485-6.

Diniz NM, Lopes RL, Gesteira SM, Alves SL, Gomes NP. Violência conjugal: vivências expressas em discursos masculinos. [Spouse violence: experiences expressed in male narratives]. Rev Esc Enferm USP. 2003;37(2):81-8.

Durand JG. Gestação e violência: estudo com usuárias de serviços públicos de saúde da grande São Paulo [dissertação]. São Paulo: Faculdade de Medicina da Universidade de São Paulo; 2006.

Edin KE, Hogberg U. Violence against pregnant women will remain hidden as long as no direct questions are asked. Midwifery. 2002;18(4):268-78.

Estrada JHM. Género y salud: articulación necesaria, desafío inaplazable. [Gender and health: a necessary articulation, an undeferable challenge]. Rev Fac Nac Salud Pública. 2005;23(1):71-7.

Féres-Carneiro T. Casamento contemporâneo: o difícil convívio da individualidade com a conjugalidade. [Contemporary marriage: the difficult association between individuality and conjugality]. Psicol Reflex Crit. 1998;11(2):379-94.

Fiol EB, Pérez VAF La violencia de género: De cuestión privada a problema social. [Gender violence: From a private issue to a social problem]. [citado 2007 abr. 23]. Disponível em: http://www.nodo50.org/mujeresred/violencia-bosch-ferrer-1.html. 
Flores Sullca T. Violência como fator de risco para gravidez na adolescência, Puno - Peru. [Violence as factor of risk for pregnancy in the adolescence, Puno-Peru] [dissertação]. São Paulo: Universidade Federal de São Paulo—Escola Paulista de Medicina; 2004.

Fonseca RMGS, Egry EY, Bertolozzi, MR. O materialismo histórico e dialético como teoria da cognição e método para a compreensão do processo saúde-doença. In. Egry EY, Cubas MR. O Trabalho da enfermagem em saúde coletiva no cenário CIPESC. Guia para pesquisadores. Associação Brasileira de Enfermagem. Curitiba, 2006. 19-61.

Fonseca RMGS, Egry EY. A potencialidade das Oficinas de Trabalho CríticoEmancipatórias reinterpretada por meio da utilização da dinâmica da Árvore do Conhecimento. Revista da Escola de Enfermagem da USP; 2007 (enviado para publicação)

Fonseca ALB, Araujo NG. Maternidade precoce: uma das consequiências do abandono escolar e do desemprego. [Premature pregnancy: one of the consequences of school dropout and unemployement]. Rev Bras Crescimento Desenvolv Hum. 2004;14(2):16-22.

Fonseca RMGS. Investigando, construindo e reconstruindo a enfermagem generificada através das Oficinas de Trabalho. In: Anais do $2^{-}$Encontro Internacional de Pesquisa em Enfermagem: Trajetória Espaço-Temporal da Pesquisa; 2002 out. 28-31; Águas de Lindóia, SP. Águas de Lindóia: EEUSP; 2002.

Foucault M. Microfísica do poder. Rio de Janeiro: Graal; 2001.

Fundação Carlos Chagas. Mulheres brasileiras, educação e trabalho. [citado 2007 abr. 20]. Disponível em: http://www.fcc.org.br/mulher/series_historicas/mbet.html.

Fundação Perseu Abramo. A mulher brasileira nos espaços público e privado. [atualizado em 2006 abr. 05; citado 2007] Disponível em: http://www2.fpa.org.br/portal/modules/wfdownloads/viewcat.php?cid=17

Galvão JB. Violência intrafamiliar contra mães de crianças de uma creche municipal em São Paulo [dissertação]. São Paulo: Faculdade de Saúde Pública da Universidade de São Paulo; 2002. 
Garbin CAS, Garbin AJI, Dossi AP, Dossi MO. Violência doméstica: análise das lesões em mulheres. [Domestic violence: an analysis of injuries in female victims]. Cad Saude Publica. 2006;22(12):2567-73.

Garcia-Moreno C, Jansen HA, Ellsberg M, Heise L, Watts CH; WHO Multi-country Study on Women's Health and Domestic Violence against Women Study Team. Prevalence of intimate partner violence: findings from the WHO multi-country study on women's health and domestic violence. Lancet. 2006;368(9543):1260-9.

Giddens A. transformação da intimidade: sexualidade, amor \& erotismo nas sociedades modernas". São Paulo: Unesp; 1993.

Gomes MCPA, Pinheiro R. Acolhimento e vínculo: práticas de integralidade na gestão do cuidado em saúde em grandes centros urbanos. [Reception and attachment: integral practices in health care administration in large urban centers]. Interface Comunic Saúde Educ. 2005;9(17):287-301.

Gracia E, Herrero J. Acceptability of domestic violence against women in the European Union: a multilevel analysis. J Epidemiol Community Health. 2006;60(2):123-9.

Grossi PK. Violência contra a mulher: implicações para os profissionais de saúde. In: Lopes MJM, Meyer DE, Waldow VR. Gênero e saúde. Porto Alegre: Artes Médicas; 1996. p. 131-49.

Hardy E, Jiménez AL. Masculinidad y Género. [Masculinity and gender]. Rev Cuba Salud Pública. 2001;27(2):77-88.

Hartigan P. La OPS enfoca el problema de la violencia contra la mujer. [PAHO focuses on the problem of violence against women]. Rev Panam Salud Pública = Pan Am J Public Health. 1997;2(4):290-4.

Heise L, Ellsberg M, Gottemoeller M. Ending violence against women. Popul Rep. 1999;27(4):1-43.

Heise L. Gender based abuse: the global epidemic. Cad Saude Publica = Rep Public Health. 1994;10(supl.1):135-45. 
Heller A. Sobre os papéis sociais. In: Heller A. O cotidiano e a história. 4ª ed. São Paulo: Paz e Terra; 1992. p. 87-110.

Houaiss A, Villar MS. Dicionário Houaiss da Língua Portuguesa. Rio de Janeiro: Objetiva; 2004.

Humberg LV. Dependência do vínculo: uma releitura do conceito de codependência [dissertação]. São Paulo (SP) Faculdade de Medicina da Universidade de São Paulo; 2004.

IBGE, 2003 /2004 www.ibge.gov.br, indicadores 2003

Instituto Brasileiro de Geografia e Estatística. O trabalho da mulher principal responsável no domicílio. [atualizado em 19 abr. 2007; citado 2006 ago.]. Disponível em:

http://www.ibge.gov.br/home/estatistica/indicadores/trabalhoerendimento/pme_nova/ apresentacao_mulher_responsavel.pdf.

Instituto Patrícia Galvão. Onde tem violência, tudo mundo perde. [citado 200715 mar]. Disponível em: http://www.patriciagalvao.org.br.

Ipas Brasil. Editorial. Revista de Saúde Sexual e Reprodutiva. Informativo Eletrônica de IPAS Brasil. Edição n⿳o 20. [atualizado em 2007 mar. 15; citado 2005 nov.]. Disponível em: http://www.ipas.org.br/revista/nov05.html.

Ipas Brasil. Ipas e a violência contra a mulher. (Conselho Social e Econômico, Nações Unidas, 1992). [citado 200715 mar]. Disponível em: http://www.ipas.org.br/violencia.html.

Izumino WP. Justiça e violência contra a mulher: o papel do sistema judiciário na solução dos conflitos de gênero. São Paulo: Annablume: 2004.

Jaggar AM. Amor e conhecimento: a emoção na epistemologia feminista. In: Jaggar AM, Bordo SR. Gênero, corpo, conhecimento. Rio de Janeiro: Record: Rosa dos Tempos, 1997. p. 157-85. 
Jong LC. Perfil epidemiológico da violência doméstica contra a mulher em cidade do interior paulista [dissertação]. São Paulo: Faculdade de Saúde Pública da Universidade de São Paulo; 2000.

Kim J, Motsei M. "Women enjoy punishment": attitudes and experiences of genderbased violence among PHC nurses in rural South Africa. Soc Sci Med. 2002;54(8):1243-54.

Kronbauer JF, Meneghel SN. Perfil da violência de gênero perpetrada por companheiro. [Profile of gender violence by intimate partners]. Rev Saude Publica. 2005;39(5):695-701.

Krug EG, Dahlberg LL, Mercy JA, Zwi AB, Lozano R. World report on violence and health. Geneva: World Heath Organization; 2002.

Langely R, Levy RC. Mulheres espancadas: fenômeno invisível. São Paulo: Hucitec; 1980.

Lebas J, Morvant C, Chauvin P. Les conséquences des violences conjugales sur la santé des femmes et leur prise en charge en médecine de premier recours. [Consequences of domestic violence on women's health and their management in primary health care]. Bull Acad Natl Med. 2002;186(6):949-59; discussion 959-61.

Lee RK, Thompson VL, Mechanic MB. Intimate partner violence and women of color: a call for innovations. Am J Public Health. 2002;92(4):530-4.

Lourenço MAE. A saúde da mulher e gravidez na adolescência: estudo comparado sobre as repercussões para a vida da jovem no Rio de Janeiro - Brasil e Maputo Moçambique. [Woman health and pregnancy in adodeslcence: comparate study on repercussions to young girl life in Rio de Janeiro - Brazil and Maputo Mozanbique]. Rio de Janeiro. 2003;s.n.

Louro GL. Gênero, sexualidade e educação: uma perspectiva pós-estruturalista. Petrópolis: Vozes; 1997.

Meneghel SN, Camargo M, Fasolo LR, Mattiello DA, da Silva RC, Santos TC, et al. Mulheres cuidando de mulheres: um estudo sobre a Casa de Apoio Viva Maria, Porto Alegre, Rio Grande do Sul, Brasil. [Women caring for women: a study at the 
Viva Maria shelter, Porto Alegre, Rio Grande do Sul, Brazil]. Cad Saude Publica. 2000;16(3):747-57.

Mello VP, Amaral MA, Fonseca RMGS. Adolescência, sexualidade e gênero: possibilidades das Oficinas de Trabalho Critico-Emancipatórias. Revista Mineira de Enfermagem; 2007 (enviado para publicação).

Menezes TC, Amorim MMR, Santos LC, Faúndes A. Violência física doméstica e gestação: resultados de um inquérito no puerpério. [Domestic physical violence and pregnancy: results of a survey in the postpartum period]. Rev Bras Ginecol Obstet. 2003;25(5):309-16.

Miller L. Protegendo as mulheres da violência doméstica. In: Moraes MLQ, Naves R. Advocacia pro bono - em defesa da mulher vítima de violência. Campinas: Unicamp e Imprensa Oficial do Estado; 2002. p. 223-63.

Minayo MCS. O desafio do conhecimento: pesquisa qualitativa em saúde. São Paulo: Hucitec; 2004.

Minayo MCS. Violência e saúde. Rio de Janeiro: Fiocruz; 2006

Minayo MCS. Violência social sob a perspectiva da saúde pública. [Social violence from a public health perspective]. Cad Saúde Pública. 1994;10(supl 1):7-18.

Mota JC. Violência contra a mulher praticada pelo parceiro íntimo: estudo de um serviço de atenção especializada. [Violence against the woman practised for the close partner: study of a service of specialized attention] [dissertação]. Rio de Janeiro: Escola Nacional de Saúde Pública Sergio Arouca; 2004.

Nasir K, Hyder AA. Violence against pregnant women in developing countries: review of evidence. Eur J Public Health. 2003;13(2):105-7.

Negreiros TCGM, Féres-Carneiro T. Masculino e feminino na família contemporânea. Estud Pesqui Psicol, 2004;4:34-47.

Noronha CV, Daltro ME. A violência masculina é dirigida para Eva ou Maria? [Is male violence directed towards Eve or Mary?]. Cad Saude Publica. 1991;7(2):21531 . 
Núñez-Rivas HP, Monge-Rojas R, Gríos-Dávila C, Elizondo-Ureña AM, RojasChavarría A. La violencia física, psicológica, emocional y sexual durante el embarazo: riesgo reproductivo predictor de bajo peso al nacer en Costa Rica. [Physical, psychological, emotional, and sexual violence during pregnancy as a reproductive-risk predictor of low birthweight in Costa Rica]. Rev Panam Salud Pública = Pan Am J Public Health. 2003;14(2):75-83.

Odalia N. O que é violência. São Paulo: Brasiliense; 2004.

Oliveira CC. Práticas dos profissionais das equipes de saúde da família voltadas para mulheres em situação de violência sexual: uma abordagem de gênero [tese]. São Paulo: Escola de Enfermagem da Universidade de São Paulo; 2005.

Organización Panamericana de la Salud. La violencia contra las mujeres: responde el sector salud. Washington: Organización Panamericana de la Salud; 2003.

Oshikata CT, Bedone AJ, Faúndes A. Atendimento de emergência a mulheres que sofreram violência sexual: características das mulheres e resultados até seis meses pós-agressão. [Emergency care for women following sexual assault: characteristics of women and six-month post-aggression follow-up]. Cad Saude Publica. 2005;21(1):192-9.

Pernambuco.com. Agressor não acha que cometeu crime. [atualizado em 2007 abr. 17; citado 2004]. Disponível em:

http://www.pernambuco.com/comunidade/mulher/violencia_perfildoagressor.html.

Piccinini CA, Ferrari AG, Levandowski DC, Lopes RS, Nardi TC. O bebê imaginário e as expectativas quanto ao futuro do filho em gestantes adolescentes e adultas. [The imaginary baby and the expectations regarding the childÆs future in adolescent and adult pregnant women]. Interações Estud Pesqui Psicol. 2003;8(16):81-108.

Polezze G. Mulher e homem constroem a paz. Jornal de Araraquara 2005 nov 27; p.16.

Prefeitura de Araraquara. Morada da Cidadania. [atualizado em 2007 mar. 15; citado 2006]. Disponível em: http://www.araraquara.sp.gov.br/. 
Rago M. Ser mulher no século XXI ou Carta de Alforria. In: Venturi G, Recamán M, Oliveira S. A mulher brasileira nos espaços público e privado. São Paulo: Fundação Perseu Abramo; 2004. p. 31-42.

Ramão SR, Meneghel SN, Oliveira C. Nos caminhos de Iansa: cartografando a subjetividade de mulheres em situação de violência de gênero. [In the paths of Iansa: mapping the subjectivity of women who are victims of gender violence]. Psicol Soc. 2005;17(2):79-87.

Reichenheim ME, Moraes CL, Szklo A, Hasselmann MH, de Souza ER, Lozana Jde A, et al. The magnitude of intimate partner violence in Brazil: portraits from 15 capital cities and the Federal District. Cad Saude Publica. 2006;22(2):425-37.

Reis JN, Martin CC, Ferriani MG. Mulheres vítimas de violência sexual: meios coercitivos e produção de lesões não-genitais. [Female victims of sexual abuse: coercive methods and non-genital injuries]. Cad Saude Publica. 2004;20(2):465-73.

Saffioti H. Gênero, patriarcado, violência. São Paulo: Fundação Perseu Abramo; 2004

Saffioti HIB. O estatuto teórico da violência de gênero. In. Santos JVT. Violência em tempo de globalização. São Paulo: Hucitec, 1999. p. 142-63.

Saffioti, HIB. O poder do macho. São Paulo: Moderna; 1987.

Santos CM, Izumino WP. Violência contra as mulheres, gênero e cidadania. [citado 2007 abr. 18]. Portal Violência contra a Mulher. Disponível em:

http://www.patriciagalvao.org.br/apc-aa-patriciagalvao/home/noticias.shtml?x=193.

Santos LL. A visibilidade da violência de gênero em dois serviços de assistência primária à saúde [dissertação]. Ribeirão Preto: Faculdade de Medicina de Ribeirão Preto da Universidade de São Paulo; 2003.

Schraiber L, d'Oliveira AF, Hanada H, et al. Violência vivida: a dor que não tem nome. [Violence experienced: the nameless pain]. Interface Comun Saúde Educ. 2003;7(12):41-54. 
Schraiber LB, d’Oliveira, AFPL. Violência doméstica e saúde: o que podem fazer os serviços de saúde e seus profissionais? Secretaria de Estado da Saúde de São Paulo. Programa Qualis I e PSF. s/d.

Schraiber LB, D'Oliveira AFPL, Strake SS, Liberman MD. Violência contra mulheres e políticas de saúde no Brasil: o que podem fazer os serviços de saúde? Revista USP. 2001;51.

Schraiber LB, d'Oliveira AF, França I, Pinho AA. Violência contra a mulher: estudo em uma unidade de atenção primária à saúde. [Violence against women: a study in a primary healthcare unit]. Rev Saude Publica. 2002;36(4):470-7.

Schraiber LB, D'Oliveira AFLP. Violência contra mulheres: interfaces com a Saúde. [Violence against women: interfaces with Health care]. Interface Comun Saúde Educ. 1999;3(5):11-26.

Schraiber LB, d'Oliveira AFPL, Falcão MTC, Figueiredo WS. Violência dói e não é direito: a violência contra a mulher, a saúde e os direitos humanos. São Paulo: Unesp; 2005.

Schraiber LB, D'Oliveira AFPL. O que devem saber os profissionais de saúde para promover os direitos e a saúde das mulheres em situação de violência doméstica. Projeto Gênero, violência e Direitos Humanos - Novas Questões para o Campo da Saúde. $2^{\underline{a}}$ ed. São Paulo: Fundação Ford, CREMESP; 2003.

Scott J. Gênero: uma categoria útil para a análise histórica. $2^{2}$ ed. Recife: SOS Corpo; 1995.

Silva IV. Violência contra mulheres: a experiência de usuárias de um serviço de urgência e emergência de Salvador, Bahia, Brasil. [Violence against woman: clients of emergency care units in Salvador]. Cad Saude Publica. 2003;19(Suppl 2):S26372.

Silva L, Tonete VLP. A gravidez na adolescência sob a perspectiva dos familiares: compartilhando projetos de vida e cuidado. [Adolescent pregnancy from a family perspective: sharing projects of life and care]. Rev Latinoam Enfermagem. 2006;14(2):199-206. 
Siqueira MJT. Novas formas de paternidade: repensando a função paterna à luz das práticas sociais. In: Silva AL, Lago MCS, Ramos TR, organizadores. Falas de gênero. Florianópolis: Mulheres; 1999. p. 187-202.

Soares V. O feminismo e o machismo na percepção das mulheres brasileiras. In: Venturi G, Recamán M, Oliveira S. A mulher brasileira nos espaços público e privado. São Paulo: Fundação Perseu Abramo; 2004. p.166.

Sorj B. Trabalho remunerado e trabalho-não remunerado. In: Venturi G, Recamán M, Oliveira S. A mulher brasileira nos espaços público e privado. São Paulo: Fundação Perseu Abramo; 2004. p. 107-120.

Sousa BA. Violência no quadro institucional psiquiátrico. [atualizado em 2007 mar. 16; citado 2004 abr. 20]. Disponível em:

http://www.violencia.online.pt/scripts/cv.dll?sec=colaboracoes\&pass=BraulioSousa

Sutherland CA, Bybee DI, Sullivan CM. Beyond bruises and broken bones: the joint effects of stress and injuries on battered women's health. American Journal of Community Psychology. 2002[cited 2007 mar 15];30(5):609-36. Disponível em: http://www.springerlink.com/content/fhb01hegnf9lwggk/.

Tavares DMC. Violência doméstica: uma questão de saúde pública [dissertação]. São Paulo: Faculdade de Saúde Pública da Universidade de São Paulo; 2000.

Teles MAA, Melo M. O que é violência contra a mulher. In: Teles MAA, Melo M. O que é violência contra a mulher. São Paulo: Brasiliense; 2002.

Trindade RFC. Entre o sonho e a realidade: maternidade na adolescência sob a ótica de um grupo de mulheres da periferia da cidade de Maceió-Alagoas [tese]. Ribeirão Preto: Escola de Enfermagem de Ribeirão Preto da Universidade de São Paulo; 2005.

Vaistman J. Gênero, identidade, casamento e família na sociedade contemporânea. In: Puppin AB, Muraro RM. Mulher, gênero e sociedade. Rio de Janeiro: Relume Dumará; 2001. p. 13-20.

Vaiz Bonifaz RG, Nakano AMS. La violencia intrafamiliar, el uso de drogas en la pareja, desde la perspectiva de la mujer maltratada. [The violence intrafamiliar, the 
use of drugs in the couple, from the mistreated woman's perspective]. Rev Latinoam Enfermagem. 2004;12(n.esp):433-8.

Valdez Rojas JC, Salasar Lima A, Hernández Morejón E, Domínguez Sánchez M, Torres Diañez R, Barbosa Rodríguez D. Violencia Intrafamiliar. Enfoque de gênero. [Intrafamily violence. Gender approach]. Rev Cuba Med Gen Integr. 2002;18(4).

Venturi G, Recamán M, Oliveira S. A mulher brasileira nos espaços público e privado. São Paulo: Fundação Perseu Abramo; 2004.

Venturi G, Recamán M. As mulheres brasileiras no início do século XXI. In: Venturi G, Recamán M, Oliveira S. A mulher brasileira nos espaços público e privado. São Paulo: Fundação Perseu Abramo; 2004. p. 15-29.

Vieira DR, Palavezzini J. Um novo olhar sobre a violência contra a mulher. In: Anais do VII Seminário Fazendo Gênero; 2006 ago. 28-30; Florianópolis (SC). [atualizado em 2007 abr. 17; citado 2006 ago. 30]. Disponível em: http://www.fazendogenero7.ufsc.br/artigos/V/Vieira-Palavezzini_05_A.pdf.

Worden AP, Carlson BE. Attitudes and beliefs about domestic violence: results of a public opinion survey: II. Beliefs about causes. J Interpers Violence. 2005;20(10):1219-43.

Yoshihama M. Breaking the web of abuse and silence: voices of battered women in Japan. Soc Work. 2002;47(4):389-400.

Zink T, Levin L, Wollan P, Putnam F. Mothers' Comfort with Screening Questions about Sensitive Issues, Including Domestic Violence. J Am Board Fam Med. 2006;19(4):358-67. 
ANEXO 1 
ANEXO 2 


\section{Termo de consentimento livre e esclarecido}

Eu, Rosa Maria Godoy Serpa da Fonseca, enfermeira e professora da Escola de Enfermagem da Universidade de São Paulo (EEUSP), estou desenvolvendo uma pesquisa com finalidade acadêmica e difusão da ciência, cujo título é "As práticas dos profissionais das equipes de Saúde da Família com mulheres que sofrem violência sexual: uma abordagem de gênero". A sua colaboração será da maior importância para a realização deste trabalho, motivo pelo qual solicito a sua participação. $O$ seu consentimento em participar da pesquisa deve considerar as seguintes informações:

1. A pesquisa se justifica pela necessidade de reflexão acerca da formação e preparação dos profissionais de saúde das equipes do Programa de Saúde da Família no atendimento das mulheres que sofrem violência sexual. A reflexão sobre o atendimento neste modelo assistencial é fundamental para a qualificação dos trabalhadores das equipes, considerando que o atendimento de cada problema que demanda os serviços de saúde tem a sua especificidade e, neste caso, de forma nenhuma pode incidir apenas no aspecto biológico.

2. Os objetivos propostos são: identificar e analisar as práticas dos profissionais das equipes de saúde da família com mulheres que sofrem violência sexual; identificar a percepção dos profissionais que atuam nas equipes de saúde da família sobre a violência sexual contra a mulher.

3. A investigação está ancorada nas teorias de gênero e a coleta de dados primários será feita através de oficinas de trabalho, cujos dados serão analisados pela técnica de análise de discurso.

4. A participação é voluntária, tendo o participante liberdade para desistir durante o processo de coleta de dados, caso venha desejar, sem risco de qualquer penalização por conta disto.

5. Será garantido o seu anonimato por ocasião da divulgação dos resultados e guardado o sigilo de dados confidenciais.

6. Caso sinta necessidade de contatar a pesquisadora durante ou após a coleta de dados, poderá fazê-lo pelos telefones (11) 3066-7503 ou pelo correio eletrônico rmgsfon@usp.br . Estarei à disposição para atendê-lo(a).

7. Os dados serão coletados por meio de participação em uma Oficina de Trabalho e relato de casos por escrito e lhe será permitido ter acesso a eles quando o desejar.

8. Os dados da Oficina de Trabalho serão gravados as sessões serão filmadas.

9. Ao final da pesquisa, se for do seu interesse, será livre o seu acesso ao conteúdo da mesma, podendo discutir os dados e os resultados com a pesquisadora. 
Estou ciente das informações referentes ao Projeto "As práticas dos profissionais das equipes de Saúde da Família com mulheres que sofrem violência sexual: uma abordagem de gênero" e concordo em participar do estudo. Concordo com a gravação da minha fala e da minha imagem. Estou ciente de que os dados serão utilizados apenas para fins científicos.

São Paulo, 21 de novembro de 2005.

Nome e assinatura - Participante

Rosa Maria Godoy Serpa da Fonseca - Pesquisadora

Neusa Maria Franzoi - Pesquisadora

"Práticas profissionais e violência contra as mulheres: um recorte de gênero e classe social" 